Universidade de Brasília

Faculdade de Ciência da Informação

Programa de Pós-Graduação em Ciência da Informação

MIRIAN FERREIRA ALVES

\title{
O papel das Bibliotecas Públicas na promoção do Letramento Informacional: a percepção dos bibliotecários
}

BRASÍLIA 


\section{O papel das Bibliotecas Públicas na promoção do Letramento Informacional: a percepção dos bibliotecários}

Dissertação de Mestrado, apresentada ao Programa de Pós-Graduação em Ciência da Informação, como requisito parcial para obtenção do título de Mestre em Ciência da Informação.

Linha de Pesquisa: Comunicação e Mediação da Informação

Grupo de Pesquisa: Biblioteca e Sociedade Orientador: Professor Doutor Emir José Suaiden

BRASÍLIA 


\section{FOLHA DE APROVAÇÃO}

Título: O papel das Bibliotecas Públicas na promoção do Letramento Informacional: A percepção dos bibliotecários.

Autor (a): Mirian Ferreira Alves

Área de concentração: Gestão da informação

Linha de pesquisa: Organização da Informação

Dissertação submetida à Comissão Examinadora designada pelo Colegiado do Programa de Pós-graduação em Ciência da Informação da Faculdade em Ciência da Informação da Universidade de Brasília como requisito parcial para obtenção do título de Mestre em Ciência da Informação.

Dissertação aprovada em: 29 de junho de 2015.

\section{prof. Dr. Emir Jose Suaiden}

Presidente (UnB/PPGCINF)

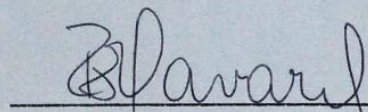

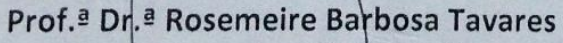

Membro Interno (UnB/PPGCINF)

Nari de Fotme Gabelin. Prof.a/Dr. a Maria de Fátima Garbelini Membro Externo (UFG)

Prof. Dr. Fernando César Lima Leite Suplente (UnB/PPGCINF) 
A472b Alves, Mirian Ferreira.

O papel das Bibliotecas Públicas na promoção do Letramento Informacional: a percepção dos bibliotecários / Mirian Ferreira Alves - 2015.

Dissertação (Mestrado) - Universidade de Brasília, Faculdade de Ciência da Informação, Programa de Pós-Graduação em Ciência da Informação, 2015.

Orientação: Emir Suaiden.

1. Biblioteca Pública. 2. Letramento Informacional. 3. Bibliotecários. 4. Fenomenografia. I. Suaiden, Emir. II. Título. 
À memória do meu avô Benedito. 


\section{AGRADECIMENTOS}

Agradeço em primeiro lugar a Deus, que me sustenta todos os dias e me abençoa com saúde e coragem para trabalhar pelos meus sonhos e ideais. Em especial, agradeço à minha mãe que me ensinou desde muito cedo sobre o valor dos estudos e o poder transformador do conhecimento. Ao meu anjo, meu esposo Abner, agradeço infinitamente o companheirismo durante esta jornada, a paciência, o amor e o apoio incondicional. A todos os meus amigos que me apoiaram e me encorajaram, em especial à minha querida amiga Thalita que foi sem dúvida, a minha maior incentivadora. - Sem a sua ajuda eu não teria conseguido, amiga, você tem a minha eterna gratidão! A todos os colegas com quem tive o prazer de conviver, compartilhar e aprender durante as aulas. Em especial agradeço a Cecília, que foi minha colega na graduação e que tive a grata surpresa de reencontrar no mestrado e aprofundar os laços de amizade. Ao querido Professor Emir Suaiden, que é mais que um orientador, é um mestre, com profunda autoridade e conhecimento. Agradeço a generosidade e os conselhos sempre tão cheios de sabedoria. Aos professores Fernando Leite, Rosemeire Barbosa Tavares e Maria de Fátima Garbelini, que gentil e prontamente aceitaram fazer parte da minha banca de qualificação e de defesa e por enriquecerem o meu trabalho com as suas contribuições. E a todos os professores que compartilharam os seus conhecimentos e enriqueceram a minha experiência de aprendizado. Aos bibliotecários que aceitaram ser entrevistados e participar da pesquisa, meu profundo agradecimento por me brindar a oportunidade de conhecer as suas experiências e aprender com elas. Enfim, agradeço a todos que torceram por mim e àqueles que direta ou indiretamente contribuíram para a realização e o êxito deste trabalho. 
“Não basta saber ler que 'Eva viu a uva'. É preciso compreender qual a posição que Eva ocupa no seu contexto social, quem trabalha para produzir a uva e quem lucra com esse trabalho. " 


\section{RESUMO}

A Sociedade da Informação e do Conhecimento apresenta novos desafios e oportunidades para as Bibliotecas Públicas, que são apontadas por diversos autores como instituição essencial para a formação de cidadãos plenos, aptos à sobrevivência na Sociedade da Informação. Neste contexto destaca-se o letramento informacional, conceito relacionado ao aprender a aprender, ao aprendizado permanente ao longo da vida e à informação para a resolução de problemas, essencial para a formação de aprendizes autônomos, capazes de reconhecer suas necessidades de informação, além de acessá-la e utilizá-la de modo crítico e ético. Sendo o bibliotecário o profissional responsável pelas ações destinadas ao desenvolvimento do letramento informacional em sua comunidade e a influência que os seus conceitos e percepções sobre o fenômeno exercem em sua atuação e posicionamento em relação à questão, o estudo teve como objetivo identificar e descrever as diferentes concepções de bibliotecários atuantes nas bibliotecas públicas estaduais brasileiras sobre o letramento informacional. A metodologia, de abordagem qualitativa e caráter exploratório utilizou como método a fenomenografia. Entrevistas individuais em profundidade foram utilizadas como instrumento de coleta de dados. Foram identificadas quatro categorias de descrição e uma subcategoria, que representam as formas qualitativamente diferentes de compreensão e vivência do letramento informacional pelos bibliotecários entrevistados. A pesquisa representa uma das primeiras tentativas de inserção da biblioteca pública nas discussões sobre letramento informacional no Brasil e possibilitou ampliar o conhecimento sobre uma questão ainda pouco explorada.

PALAVRAS-CHAVE: Bibliotecas públicas. Letramento informacional. Bibliotecários. Fenomenografia. 


\begin{abstract}
The Information and Knowledge Society presents new challenges and opportunities for public libraries, which are identified by several authors as an essential institution for the formation of active citizens, able to survive in the Information Society. In this context it highlights the information literacy concept related to learning to learn, to lifelong learning throughout life and information for problem-solving, critical to the formation of self-directed learners, able to recognize their information needs, and access it and use it in a critical and ethical way. Being the professional librarian responsible for the actions for the development of information literacy in your community and the influence that their concepts and perceptions on the phenomenon engaged in its performance and positioning on the issue, the study aimed to identify and describe the different conceptions of librarians active in the Brazilian state public libraries on information literacy. The methodology of qualitative approach and exploratory used as a method to fenomenografia. Individual in-depth interviews were used as data collection instrument. Description of four categories were identified and a subcategory, representing qualitatively different forms of understanding and experience of information literacy by respondents librarians. The research is one of the first attempts to insert the Public Library in discussions on information literacy in Brazil and possible increase knowledge about an issue not explored.
\end{abstract}

KEYWORDS: Public Libraries. Information literacy. Librarians. Phenomenography. 


\section{LISTA DE QUADROS}

Quadro 1: Declarações e Recomendações sobre Letramento Informacional ...........29

Quadro 2: Modelo ISP - Processo de Busca de Informação ................................35

Quadro 3: Variação Demográfica da Amostra ..............................................66

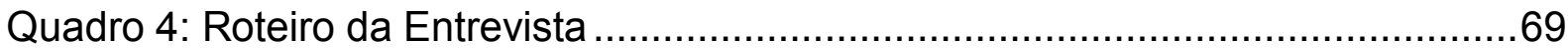

Quadro 5: Diretrizes para a seleção da amostra e coleta de dados .........................71

Quadro 6: Dimensões de variação das concepções .........................................88 


\section{LISTA DE FIGURAS}

Figura 1: Retratos da Leitura no Brasil (2011) 22

Figura 2: Retratos da Leitura no Brasil (2011) 22

Figura 3: Retratos da Leitura no Brasil (2011) 22

Figura 4: Contextos de Letramento Informacional 31

Figura 5: Diretrizes para o desenvolvimento eficaz de letramento informacional em bibliotecas públicas $\quad 46$

Figura 6: Referencial Teórico/Desenho da Pesquisa $\quad 59$

Figura 7: Aspecto relacional da Fenomenografia $\quad 62$

Figura 8: Estrutura hierárquica das concepções 91 


\section{SUMÁRIO}

1 INTRODUÇÃO

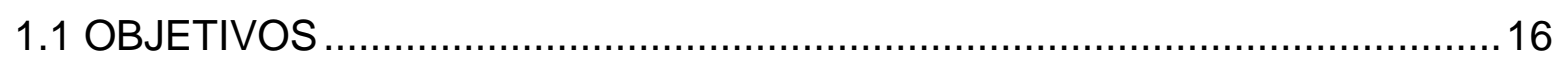

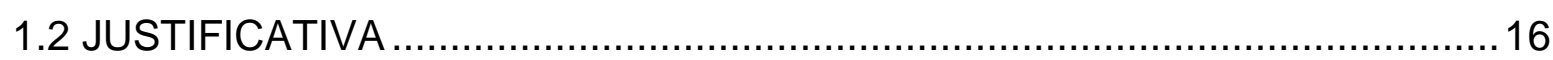

2 REVISÃO DE LITERATURA …....................................................................... 19

2.1 BIBLIOTECAS PÚBLICAS: CAMINHOS TRILHADOS E NOVOS CAMINHOS

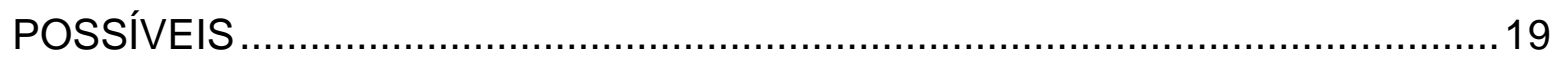

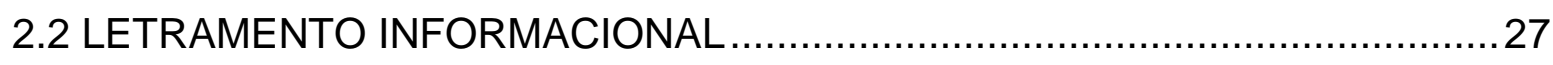

2.2.1 Letramento informacional e sociedade da informação ........................32

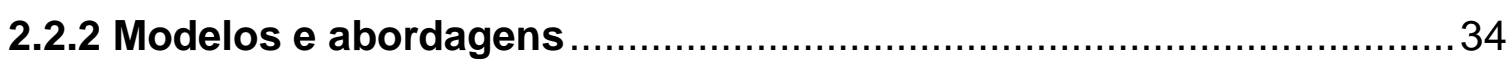

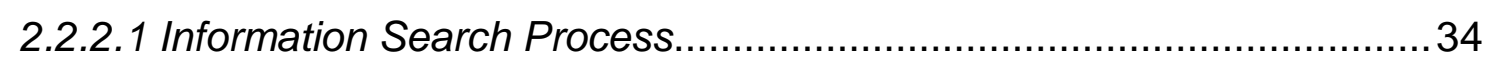

2.2.2.2 Abordagem relacional: as sete faces do letramento informacional.......36

2.2.2.3 Abordagem crítica e contextos de letramento informacional ................39

2.3 BIBLIOTECAS PÚBLICAS E LETRAMENTO INFORMACIONAL ...................41

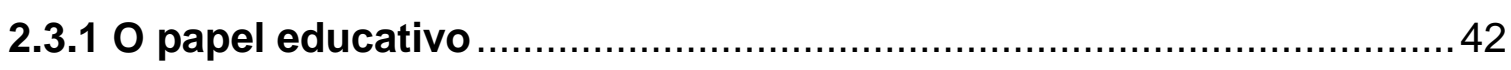

2.3.2 Inclusão digital e letramento informacional ......................................... 44

2.3.3 Elementos favoráveis ao desenvolvimento do letramento informacional em bibliotecas públicas ................................................................ 47

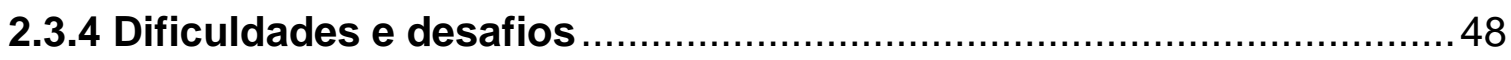

2.3.5 O bibliotecário como agente do letramento informacional...................51

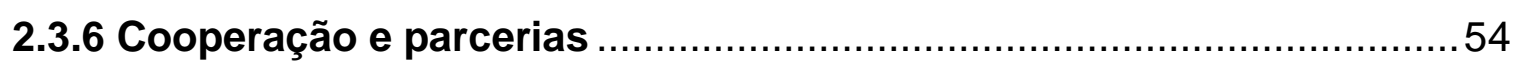

2.4 BREVES CONCLUSÕES DA REVISÃO DE LITERATURA...........................41

3 METODOLOGIA

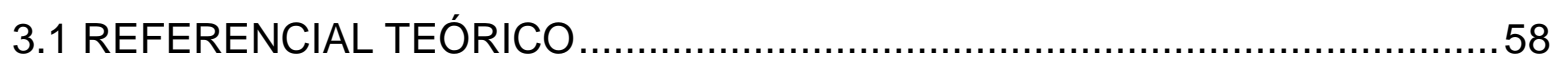

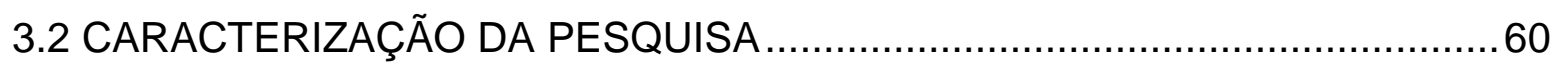

3.2.1 Fenomenografia: Aspectos ontológicos epistemológicos ..................60

3.2.2 Fenomenografia e letramento informacional ..................................... 63

3.3 SELEÇÃO DA AMOSTRA, PRÉ-TESTE E COLETA DE DADOS ...................65

3.4 MÉTODO DE ANÁLISE DE DADOS ........................................................ 72

4 ANÁLISE DOS DADOS E DISCUSSÃO DOS RESULTADOS ….........................74

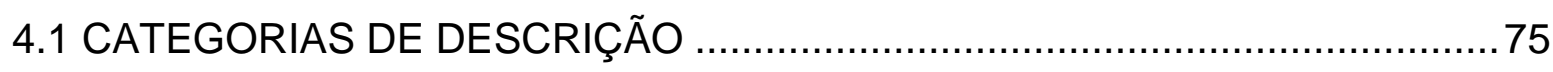

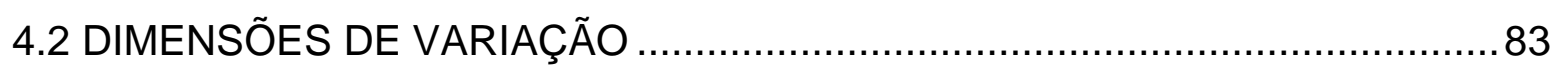

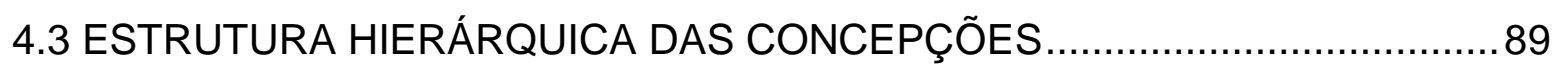

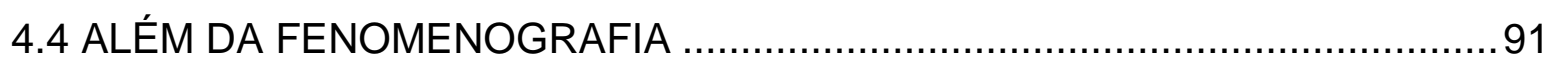




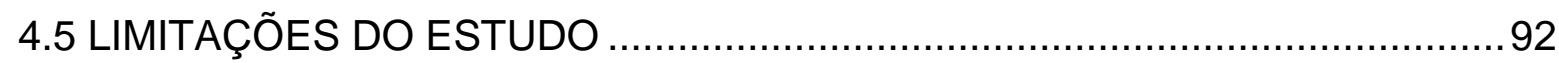

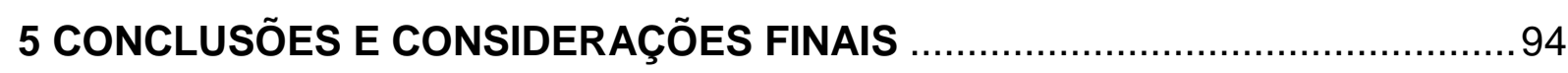

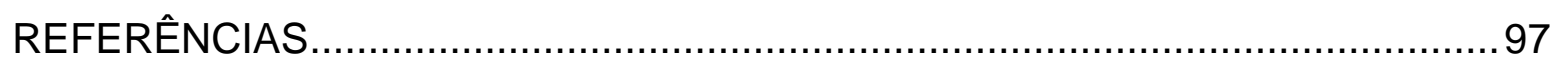




\section{INTRODUÇÃO}

O Manifesto da IFLA/UNESCO sobre a biblioteca pública (1994), a define como "portal local de acesso ao conhecimento", capaz de "proporcionar as condições básicas para a educação permanente, a tomada de decisões independentes e o desenvolvimento cultural do indivíduo e dos grupos sociais. " A biblioteca pública traz no seu bojo de finalidades e objetivos grandes desafios relacionados à educação, ao acesso à informação, à participação social e à cidadania. Estes desafios se renovam constantemente e se moldam às novas necessidades da sociedade e ao contexto histórico e social vigente.

No contexto atual, onde o conhecimento e a informação constituem as forças fundamentais nos âmbitos econômico e social, a biblioteca pública se destaca por seu potencial democrático e inclusivo e capacidade de contribuição para a formação cidadã. Mas também enfrenta novos desafios, no sentido de adaptar-se à nova realidade, às novas necessidades sociais e ao avanço tecnológico.

Esta nova ordem social, a Sociedade da Informação, é comumente entendida como uma nova forma de organização social, política e econômica baseada na informação. Conforme Castells (2003), as principais características desse novo paradigma são:

a) A informação é sua matéria-prima;

b) Os efeitos das novas tecnologias têm alta penetrabilidade;

c) Predomínio das lógicas de redes;

d) Flexibilidade; e

e) Crescente convergência das tecnologias.

Neste cenário, novas habilidades e competências são exigidas dos indivíduos, tais como: lidar com as novas tecnologias, reconhecer suas necessidades de informação, saber onde e como buscar e fazer uso crítico e ético da informação a que teve acesso, aprender a aprender e manter-se em constante aprendizagem ao longo da vida, estão entre os novos desafios. Deste modo, pode-se afirmar que o letramento informacional e a aprendizagem ao longo da vida estão estritamente relacionados com o papel da biblioteca pública e com sua atuação na Sociedade da Informação.

Letramento informacional é a capacidade de reconhecer quando a informação é necessária, onde localizar, como avaliar e utilizar a informação de modo eficaz e, em última análise, representa a capacidade de aprender a aprender (ALA, 1989). 
Para além da definição da ALA, o conceito tem sido reformulado e ampliado considerando o contexto e as relações sociais, portanto pode-se afirmar que pessoas competentes em informação tem uma maior noção, conexão e influência com o ambiente informacional. São engajadas, capazes, enriquecidas e personificadas por informações sociais, procedurais e físicas que constituem o universo informacional (LLOYD, 2005).

O letramento informacional permeia o aprendizado ao longo da vida, tendo em vista que aquele é um processo contínuo, que não se esgota. Conforme a Declaração de Alexandria (IFLA, 2005), o letramento informacional está no cerne do aprendizado ao longo da vida, por "capacitar as pessoas em todos os caminhos da vida para buscar, avaliar, usar e criar a informação de forma efetiva para atingir suas metas pessoais, sociais, ocupacionais e educacionais", sendo considerado, "um direito humano básico em um mundo digital" e que "promove a inclusão social em todas as nações".

No Brasil, o letramento informacional tem sido mais relacionado ao contexto educacional, e por isso tem seu papel mais destacado quanto às bibliotecas escolares e universitárias, ao passo que ao redor do mundo vem sendo desenvolvidos trabalhos e discussões sobre o letramento informacional, ainda que em menor grau, também no contexto das bibliotecas públicas. Estas são por sua vez, consideradas, por vocação, importantes espaços para o aprendizado ao longo da vida, dada a sua função educativa, sua penetrabilidade e presença constante na vida da comunidade. É o que ressalta Kahlert apud Harding (2008), ao afirmar que a biblioteca pública possui uma gama diversificada de usuários e potencial para alcançar todos os segmentos da comunidade de crianças a idosos, além de grupos minoritários e de distintos níveis educacionais e profissionais e por isso tem a oportunidade de desenvolvimento do letramento informacional pela comunidade.

De um modo geral, percebe-se na literatura um maior empenho no desenvolvimento dos conceitos e terminologias relacionados ao letramento informacional em detrimento de experiências práticas e aplicações empíricas (JULIEN; GENUIS, 2011; GOMEZ-HERNANDEZ e PASADAS-UREÑA, 2008; GASQUE, 2012), principalmente aquelas relacionadas à biblioteca pública.

A notável falta de literatura relacionando letramento informacional e a biblioteca pública pode sugerir que estas não estão ativamente envolvidas em esforços voltados para o letramento informacional (HARDING, 2008). No entanto, 
apesar da menor fatia de participação em relação às bibliotecas escolares e universitárias, a literatura internacional mostra que as bibliotecas públicas vêm abraçando este papel e assumindo para si esta responsabilidade.

Considerando o exposto, este trabalho pretende discutir e analisar o papel e atuação da biblioteca pública brasileira em relação ao letramento informacional, tendo como base a percepção dos profissionais que nela atuam. Neste sentido, apresentamse as questões centrais deste estudo: "Como os bibliotecários atuantes nas bibliotecas públicas estaduais brasileiras conceituam e vivenciam o letramento informacional? E qual a sua percepção sobre o papel da biblioteca pública no desenvolvimento e promoção do letramento informacional? "

\subsection{OBJETIVOS}

A partir da contextualização apresentada acima, é objetivo geral deste estudo identificar e descrever as diferentes concepções de bibliotecários atuantes nas bibliotecas públicas estaduais brasileiras sobre o letramento informacional no contexto das bibliotecas públicas.

Constituem os objetivos específicos:

- Analisar como as concepções que os bibliotecários têm do seu papel e do papel da biblioteca pública influenciam a promoção do letramento informacional;

- Examinar como as variações nas concepções de letramento informacional dos bibliotecários influenciam suas atividades profissionais;

- Mapear as possíveis ações desenvolvidas pelas Bibliotecas Públicas brasileiras na promoção do letramento informacional;

\subsection{JUSTIFICATIVA}

O presente estudo sustenta a relevância de que as bibliotecas públicas e os profissionais que nelas atuam estejam atentos constantemente às mudanças conjunturais, a fim de que possam assumir novas funções ou mesmo reinventar antigos papeis e ser capazes de identificar novas oportunidades e desafios. $\mathrm{Na}$ sociedade da informação, marcada pelas novas tecnologias e grande oferta de informação, surgem desafios e oportunidades relacionados ao letramento informacional e à educação permanente. 
Cabe às bibliotecas públicas apropriar-se de mecanismos para identificar as necessidades de aprendizagem dos membros de sua comunidade e contribuir para o desenvolvimento de usuários da informação eficazes, críticos e éticos, aptos ao exercício da cidadania e à participação democrática. As bibliotecas públicas devem modernizar-se com o objetivo de aproveitar por completo o seu potencial para aprendizagem ao longo da vida, a fim de fomentar a integração social, a criatividade e o desenvolvimento socioeconômico da comunidade a que serve (CAMPAL GARCÍA, 2008).

Apesar da relação entre biblioteca pública e letramento informacional ser notadamente clara, observa-se na literatura uma escassez de pesquisas, estudos e artigos sobre a temática. Rader, e Johnson e Jent realizaram revisões anuais da literatura em inglês nos períodos de 1937-1998 e 2000-2005, respectivamente, e ao categorizar os estudos por tipos de bibliotecas observa-se que, apenas, $2 \%$ dos artigos correspondem à biblioteca pública, com a proporção reduzida para menos de $2 \%$ nos anos mais recentes. Este percentual cresce para $52-62 \%$ quando se trata de bibliotecas universitárias e 20-35\% para bibliotecas escolares (HARDING, 2008).

No Brasil, Rodriguez (2012) verificou em seu estudo, que nos últimos dez anos somente $1 \%$ dos trabalhos publicados em Periódicos de Ciência da Informação no Brasil tratavam da biblioteca pública e temas relacionados a ela. Segundo o autor, o baixo número de artigos publicados é fruto da pouca investigação na área.

Não há investigações relacionadas ao número de estudos realizados no Brasil envolvendo, especificamente, bibliotecas públicas e letramento informacional. No entanto, pode-se afirmar com segurança que a escassez é ainda maior que na literatura internacional, ou praticamente total, uma vez que não foi localizado na literatura no Brasil nenhum estudo específico que relacione biblioteca pública e letramento informacional.

Os conceitos e aplicações do letramento informacional desenvolvidos por bibliotecários de bibliotecas públicas tem sido, conforme Demasson, Partridge e Bruce (2010), um tópico subdesenvolvido no campo da biblioteconomia e da ciência da informação. Contudo, ressaltam os autores, quaisquer que sejam os motivos reais para a situação atual, este déficit em pesquisa representa uma lacuna de conhecimento que precisa ser preenchido.

Além disso, sendo o bibliotecário o profissional responsável pela concepção e prestação de serviços e programas destinados ao desenvolvimento do letramento 
informacional em sua comunidade, pode-se afirmar que os seus conceitos e percepções sobre o fenômeno influenciam diretamente sua atuação e posicionamento em relação à questão. A partir das concepções dos profissionais eventuais possibilidades de intervenção podem ser traçadas a fim de tornar o letramento informacional mais efetivo e presente nas bibliotecas públicas.

Como evidencia Elmborg (2006), o principal desafio para fazer frente às mudanças encontra-se na visão que os bibliotecários têm de si mesmos e da profissão. Neste sentido, a presente pesquisa justifica-se por sua potencial contribuição ao buscar uma compreensão de uma questão ainda pouco explorada, e pelas implicações práticas oriundas do conhecimento do conjunto de percepções e entendimentos que os bibliotecários têm de um elemento central para a profissão, o letramento informacional. 


\section{REVISÃO DE LITERATURA}

A revisão de literatura não é e não tem a pretensão de ser exaustiva. Abrange o levantamento e discussão, em síntese, da literatura nacional e internacional, priorizando autores e resultados de estudos que guardem relação com o problema e os objetivos da pesquisa e que podem, potencialmente, contribuir com apontamentos teóricos e metodológicos para uma melhor compreensão do objeto estudado.

A revisão de literatura desdobra-se em três tópicos principais, que se desdobram em sub tópicos. O primeiro tópico aborda o tema Biblioteca Pública: caminhos trilhados e novos caminhos possíveis, onde são apresentados conforme a literatura, os conceitos, finalidades, breves apontamentos relacionados ao seu papel nos diversos contextos históricos e sociais, assim como apresenta as principais tendências de atuação para a biblioteca pública na atualidade e para o futuro.

O segundo tópico aborda o Letramento Informacional e seus sub tópicos: Sociedade da Informação e Modelos e Abordagens. Apresenta os principais conceitos, o papel do letramento informacional na sociedade da informação e os principais modelos e abordagens de letramento informacional: ISP de Kuhlthau (1991), Sete Faces do Letramento Informacional de Bruce (1997), Abordagem Crítica de Elmborg (2006) e Hall (2009) e Contextos de Letramento Informacional de Lloyd (2005).

O terceiro tópico relaciona o letramento informacional e as bibliotecas públicas. Apresenta uma evolução do papel educativo da biblioteca pública, conceitos e alguns dos principais estudos realizados no mundo sobre a temática. Por fim, é feita uma breve conclusão da revisão de literatura.

\subsection{BIBLIOTECA PÚBLICA: CAMINHOS TRILHADOS E NOVOS CAMINHOS POSSÍVEIS}

O conceito mundialmente difundido pela IFLA/UNESCO (2012) define a biblioteca pública como uma instituição que proporciona acesso ao conhecimento, à informação e à educação permanente, por meio de uma variedade de serviços, e se coloca à disposição de modo igualitário a todos os membros da comunidade sem distinção. Sua finalidade, de acordo com o Manifesto para as bibliotecas públicas (IFLA/UNESCO, 1994), inclui apoiar à educação, criar e fortalecer o hábito de leitura em crianças e jovens, oferecer oportunidades para o desenvolvimento da criatividade, 
proporcionar desenvolvimento cultural, ser o centro de informação local e atuar como espaço público e ponto de encontro da comunidade.

Conforme MORAES (1983), as bibliotecas públicas são "velhas como o mundo", existiram no tempo de Roma e proliferaram na Renascença, mas foi, especialmente, no século XIX que elas se desenvolveram. Como relata Shera apud Fonseca, a ideia da verdadeira biblioteca pública surgiu no começo do século XIX, com o movimento liderado por Horace Mann e Henry Barnard, em favor da educação para todos os segmentos da sociedade. Para estes educadores americanos, o programa nacional de educação somente se completaria com o estabelecimento de bibliotecas para todo o povo.

O surgimento e a proliferação das bibliotecas públicas no século XIX permeia a história da Biblioteconomia e da Documentação. Ortega (2004) expõe que, em função do surgimento da biblioteca pública, geral e aberta - e do crescimento dos periódicos e de sua importância na divulgação científica - a Biblioteconomia trilhou novos caminhos, passando a dividir seus espaços com as atividades desenvolvidas pela Documentação. Ademais, o movimento de surgimento e expansão das bibliotecas públicas, nos Estados Unidos e na Inglaterra, em especial, levou os bibliotecários a desviar suas atenções dos processos de análise e representação do conhecimento registrado para assumirem a função "educativa" suscitada pela biblioteca pública, então considerada uma agência educacional das massas. Com o culto à educação universal e a apropriação da função "educativa" pelo bibliotecário tradicional ou a negação do significado do serviço de informação, os documentalistas adotaram as técnicas da Biblioteconomia e as aperfeiçoaram (ORTEGA, 2004).

No Brasil a primeira biblioteca pública foi fundada em 1811 a partir de iniciativa não governamental, quando Pedro Ferrão Gomes encaminhou projeto ao então governador da Capitania da Bahia, Conde dos Arcos, solicitando a criação da biblioteca. Conde dos Arcos, por sua vez, aprovou o projeto e a biblioteca foi inaugurada na Bahia. Posteriormente foi inaugurada a biblioteca pública do estado do Maranhão em 1829. A partir daí foram criadas outras bibliotecas públicas estaduais, sempre por inciativa do governo (SUAIDEN, 1980).

No percurso histórico das bibliotecas públicas no Brasil destaca-se a atuação do Instituto Nacional do Livro (INL), criado em 1937 no governo de Getúlio Vargas, que dentre outros objetivos, visava a expansão do número de bibliotecas públicas por todo o território nacional. A avaliação da atuação do INL nos seus 52 anos de 
existência (1937-1989) é um tanto polêmica, uma vez que a intervenção por parte do Estado na produção cultural impressa e na formação dos acervos das bibliotecas públicas foi evidente. No entanto, neste período o número de bibliotecas públicas cresceu bastante no país. O próprio Sistema Nacional de Bibliotecas Públicas foi criado em 1977 pelo INL, com o objetivo de disponibilizar aos usuários bibliotecas públicas estruturadas, de modo a favorecer a formação de hábitos de leitura e estimular a comunidade a participar do desenvolvimento sociocultural do país (SUAIDEN, 1980).

O primeiro modelo de biblioteca pública instituído no Brasil pautou-se em padrões utilizados por outros países, à época mais desenvolvidos, porém sem conexão com a realidade e a cultura brasileira. A reprodução deste modelo, com forte apelo na formação e preservação da coleção, gerou problemas que trouxeram conflitos de visões entre os profissionais da informação e a comunidade: as bibliotecas públicas passaram a ser vistas como lugares elitizados, depósitos de livros e espaço para pesquisas e tarefas escolares (SUAIDEN, 2014).

Além disso, em sua trajetória histórica mediada por políticas pouco eficientes, as bibliotecas públicas no Brasil sempre padeceram com problemas estruturais, falta de recursos e de pessoal qualificado. Chega, portanto, à atualidade com a necessidade e a urgência de se reinventar e se readequar aos novos tempos e às novas necessidades sociais, ao mesmo tempo em que tem de lidar com antigos problemas.

Dados do Senso Nacional das Bibliotecas Públicas, realizado em 2009 pela Fundação Getúlio Vargas (FGV), apontam que 79\% dos municípios brasileiros possuem ao menos uma biblioteca pública em funcionamento. Este dado a coloca numa posição privilegiada como o equipamento cultural mais presente nos municípios brasileiros, sendo até mesmo o único em muitos casos. No entanto, como apontam os dados da pesquisa Retratos da Leitura no Brasil realizada em 2011, apesar de a maioria dos entrevistados afirmar ter conhecimento da existência de uma biblioteca em seu bairro ou cidade (Figura 1) - e mesmo sendo estas de fácil acesso (Figura 2) - 3 em cada 4 brasileiros não frequentam bibliotecas no país (Figura3). 
Maioria sabe que existe biblioteca por perto

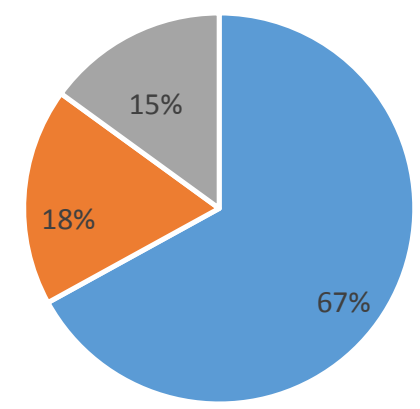

- Sabe da existência n Não sabe se existe

- Afirma não existir

Figura 1: Retratos da Leitura no Brasil (2011)

Essa biblioteca é de fácil ou difícil acesso?

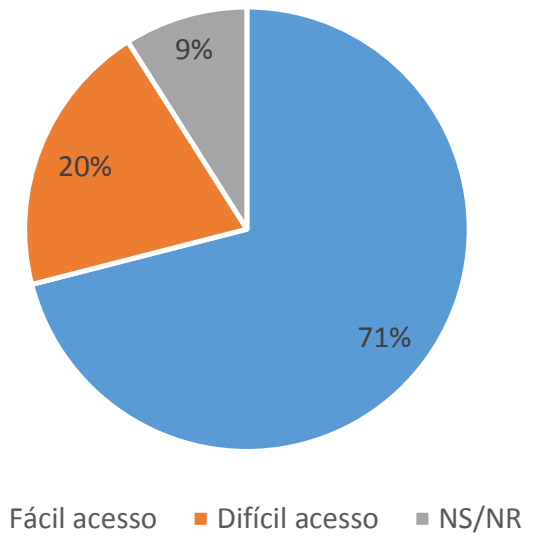

Figura 2: Retratos da Leitura no Brasil (2011)

3 em cada 4 brasileiros não vão a bibliotecas

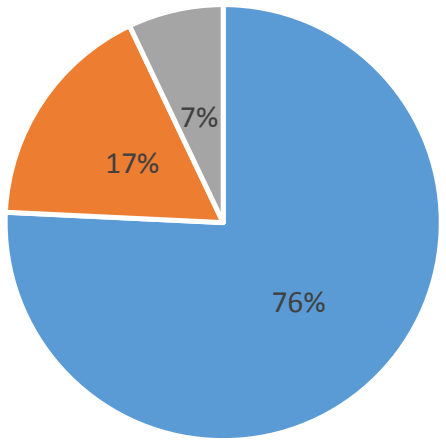

- Não usa - Usa frequentemente - Usa ocasionalmente

Figura 3: Retratos da Leitura no Brasil (2011) 
Milanesi (2002, p. 98), aponta possíveis causas para estes dados alarmantes, além de apontar caminhos para reverter este quadro:

O baixo índice de frequência adulta nesses espaços
públicos indica para duas direções: eles não satisfazem a
vontade de saber ou as pessoas não tem mesmo esse
desejo. Provavelmente é a soma das duas situações que
leva às bibliotecas desertas. A maioria da população adulta
jamais entrou numa biblioteca pública porque não
percebeu sua utilidade ou não sentiu necessidade de
acesso aos produtos e serviços que oferece. Se o
mencionado "homem comum" entra neste espaço, é
provável que muito pouco encontrará para fazer, além do
contato com livros e revistas antigos. É preciso mudar a
postura dessa organização passiva de um acervo à espera
de leitores, para uma postura proativa que cria demanda,
cria atividades e serviços que sejam claramente, estímulos
à ampliação do conhecimento pelos conflitos que suscitam
ou pelo prazem que oferecem - ou pelos dois.

Ainda nesse sentido, Lemos (1982) propõe uma reflexão, ainda hoje tão atual e relevante, a partir da seguinte questão: "o que teria a biblioteca pública a oferecer à maioria da população para que esta se aproprie efetivamente de uma instituição que, pelo adjetivo aspira ser sua? "Trata-se, conforme o autor, de refletir, discutir e conhecer o papel que a biblioteca pública deve desempenhar e examinar a situação de uma perspectiva mais ampla das desigualdades que caracterizam a sociedade brasileira.

Em busca de respostas e novos caminhos a serem trilhados para essa instituição, autores como Crippa (2015), Milanesi (2002; 2013), Herrera-Viedma e López-Gijón (2013) e Lozano Días (2006), defendem que a biblioteca pública deve reconfigurar-se como um espaço social que tenha centralidade de ação com o público e Suaiden $(2000 ; 2002 ; 2013 ; 2014)$ ressalta a atuação desta instituição como caminho para uma efetiva participação da comunidade na sociedade da informação. Estes autores reforçam a dimensão social da biblioteca pública e propõe ações baseadas na estreita vinculação com a comunidade e no convívio social, voltadas às questões e ao desenvolvimento local, à aprendizagem informacional e à construção coletiva do conhecimento.

Crippa (2015) entende que a biblioteca pública deve atuar como um "laboratório de cidadania", mais próxima dos processos cotidianos, do que de fato o é atualmente. Uma oficina de apropriação do espaço coletivo e ações compartilhadas, 
configurando-se como um rico território de encontro de realidades múltiplas, capaz de buscar saídas para crises sociais que nos cercam. Para tanto, considera, não é suficiente apenas que os bibliotecários e todo o pessoal da biblioteca possuam as necessárias competências sociológicas, de comunicação e criatividade. Além de ser um espaço que recebe, apoia e oferece tecnologias, o que de fato, permite que a biblioteca desempenhe seu papel social é a presença de cidadãos capazes de articular com essa instituição e bibliotecários capacitados para tornar suas as necessidades dos usuários, colocando-se à disposição para envolvê-los em atividades e tornar a biblioteca uma instituição mediadora.

Ainda conforme Crippa (2015), nestes tempos em que emerge a necessidade de locais públicos para reconfigurar a vida de modo menos individualista, a biblioteca pública apresenta-se como lugar de acolhimento e encontro reflexivo, espaço de encontro, mediação e construção de novos conhecimentos, a partir do suporte tecnológico e informacional que pode ofertar. Ademais, ressalta que seu ponto forte de agregação é sua própria existência como espaço físico que possibilita aos usuários não somente fruir de bens culturais mas participar ativamente de uma experiência de comunidade.

Neste sentido, Milanesi (2002) esclarece que apesar de toda a revolução tecnológica que parece ter transformado o mundo em uma aldeia, as expectativas quase sempre permanecem no âmbito da vida cotidiana. Aí reside o papel do profissional da informação: conhecer a comunidade e o seu público para planejar a informação necessária. Neste âmbito, encontra-se a oportunidade para que os serviços de informação locais se tornem insubstituíveis, incluindo atividades de discutir informações e gerar novas. A internet não destrói as bibliotecas, esclarece o autor, mas pode reforçar o interesse nas informações que compõe a vida cotidiana da cidade - que é um dos objetivos da biblioteca pública do presente e seguramente, também das do futuro.

Para Milanesi (2013), a biblioteca pública passará pelo mesmo processo que a fotografia, que não desapareceu, mas se aperfeiçoou com os recursos digitais. A sua função básica de prestar informações necessárias à coletividade se mantém, podendo ser incrementada com novos recursos. Para o autor três verbos formam a trilogia essencial das bibliotecas públicas: informar, discutir a informação e criar novas informações (grifo nosso). O primeiro verbo traz as informações demandadas ou propostas, o segundo as discute. O terceiro verbo, "criar", é o que dá o sentido 
maior das atividades de informação e de ação cultural: encontrar respostas, descobrir soluções, criar novas informações. Nesse sentido, mesmo com toda tecnologia e virtualidades, as bibliotecas públicas seguirão como espaços físicos e com horários delimitados. Isso se dará porque elas serão os locais voltados às atividades correspondentes aos verbos "discutir" e "criar", que demandam espaço e tempo, ao contrário do "informar", que prescinde deles. Portanto, a configuração física da biblioteca tradicional será alterada substancialmente. A adequação entre público/informação/espaço permitirá tornar a biblioteca útil e agradável.

Em continuidade a este raciocínio, Herrera-Viedma e López-Gijón (2013), em artigo publicado na Revista Science defendem o papel das bibliotecas como espaços sociais de convivência e democracia na sociedade da informação. Segundo os autores, para fazer a transição para este novo papel as bibliotecas devem começar a centrar-se mais nos usuários que nos acervos, ofertando espaços sociais de aprendizagem, reflexão e leitura, onde as pessoas possam compartilhar suas experiências e conhecimentos. Ou seja, a biblioteca pública deve observar a dimensão física e a criação de espaços sociais, a fim de propiciar a seus usuários um ambiente onde possam desenvolver atividades que lhes permitam crescer como cidadãos de uma comunidade.

Em uma biblioteca pública com orientação social, conforme defendida por Herrera-Viedma e López-Gijón (2013), as pessoas poderão usar a Internet, ler um livro ou um jornal, assistir a um documentário, assim como aprender a abrir uma conta bancária ou iniciar um negócio, discutir os problemas do seu bairro ou país, disfrutar de poesia, teatro ou cinema,ou aprender sobre alimentação e hábitos saudáveis, tudo enquanto toma uma bebida com outros usuários. Neste sentido, Crippa (2015) aponta ainda serviços bibliotecários voltados para a formação informal, para a information literacy, o incentivo à leitura, combinados com encontros, simpósios, exposições, música, etc., como um caminho para que a biblioteca pública possa assumir a dimensão de espaço público que lhe cabe, onde todos se encontram e se transformam, fazendo emergir novas formas participativas de cidadania.

Este foco no papel social da biblioteca pública implica em uma reflexão sobre a função e o lugar dessa instituição na sociedade atual. Incumbe pensar seriamente se para uma sociedade diferente, com cidadãos diferentes e valores diferentes nos serve o mesmo modelo de bibliotecas e de organização que herdamos do passado ou temos de considerar uma mudança rumo ao futuro. Para fazer frente a essas 
mudanças a biblioteca pública deve incorporar novas funções e oferecer novos serviços e acima de tudo, converter-se em um serviço próximo ao cidadão (LOZANO DÍAS, 2006).

A maioria das bibliotecas públicas não são "visíveis", o que provoca um distanciamento das políticas públicas e na interação com a comunidade. Para fazer frente aos desafios da sociedade do conhecimento a biblioteca terá de inovar permanentemente. Os maiores desafios, neste sentido, residem em coordenar a transição do impresso para o digital e construir usuários produtores de informação e não mais dependentes da informação, fatores estes preponderantes para a construção de comunidades autossustentáveis e sociedades justas. Em suma, a biblioteca precisa assumir seu compromisso com o mundo externo e desempenhar seu papel relacionado à educação, ao ensino, à aprendizagem informacional e disseminação dos recursos informacionais e culturais (SUAIDEN, 2000; 2013; 2014).

Suaiden (2000; 2014) aponta algumas estratégias que podem ser úteis às bibliotecas públicas, em seus esforços para inclusão de sua comunidade no contexto da sociedade da informação:

a) A utilização de metodologias qualitativas para formular diagnósticos, como uma possibilidade para estabelecer um planejamento estratégico nas bibliotecas, visando o fortalecimento dos setores identificados, a expansão das áreas de interesse mútuo da biblioteca e da comunidade e a criação de indicadores que apoiem investimentos em ações da biblioteca;

b) A adoção de metodologias de tomadas de decisão compartilhada, reforçando o seu caráter democrático e promovendo a inclusão social;

c) A utilização da segmentação de mercado. Ao invés de tentar ser "tudo para todos", buscar conhecer e atender a demandas específicas de determinados segmentos da comunidade;

As ideias e proposições dos autores citados neste tópico convergem no sentido de situar a biblioteca pública no cenário de mudanças e transição suscitados pela sociedade da informação e do conhecimento. Além disso, apontam para a necessidade de flexibilidade e reflexão a fim de buscar novos caminhos e desempenhar novos papeis ou mesmo antigos papeis de um jeito novo, de modo que continue sendo uma instituição útil aos propósitos de educação, democracia e cidadania, tão exaltados quando do seu surgimento. As tendências apontadas pelos autores citados demonstram que as bibliotecas públicas devem estimular o convívio 
social, a aprendizagem, a reflexão e a criação de novos conhecimentos, visando o desenvolvimento regional e a formação cidadã, por meio de um vínculo estreito com a comunidade.

\subsection{LETRAMENTO INFORMACIONAL}

A expressão "information literacy" foi usada pela primeira vez pelo bibliotecário americano Paul Zurkowski em 1974, em um relatório intitulado "The information service environment relationships and priorities". Zurkowski previa um contexto de mudanças para os anos seguintes e alertava para a necessidade do aprendizado de técnicas e habilidades no uso de ferramentas de acesso à informação. Recomendava neste relatório o início de um "movimento nacional em direção à information literacy".

Desde então, muito se tem discutido sobre letramento informacional, em especial no contexto atual em que se presencia um crescimento vertiginoso da quantidade de informação disponível e o desenvolvimento das novas tecnologias de informação e comunicação, que facilitam o acesso à informação. Estudiosos de todo o mundo debruçaram-se sobre as questões conceituais, epistemológicas e práticas que permeiam o letramento informacional e muitos países reconheceram formalmente a sua importância para a educação, a democracia e o exercício da cidadania.

No Brasil, o termo foi mencionado pela primeira vez por Caregnato (2000, p. 50), que o traduziu como "alfabetização informacional", e o considerou dentre as "novas formas para designar o serviço educacional oferecido pelas bibliotecas aos seus leitores", relacionando o termo com a expansão do conceito de educação de usuários.

Conforme Dudziak (2003), enquanto alguns autores defendem o novo conceito, outros afirmam que é apenas um novo nome para práticas já consolidadas. Neste sentido, Woods, Burns e Barr (1990) apud Harding (2008) apontam uma tendência de utilização do termo como sinônimo de educação de usuários e sugerem ainda, que seria apenas um novo nome para o serviço tradicionalmente ofertado pelas bibliotecas. Não obstante, Harding (2008) esclarece que são conceitos diferentes, apesar de relacionados entre si e destaca ainda que o letramento informacional representa um conceito bem mais complexo que educação de usuários, abrangendo questões que permeiam a resolução de problemas, o pensamento crítico e a capacidade para aplicar a informação na vida cotidiana. 
Muitos são os termos utilizados para traduzir a expressão, como "Alfabetização Informacional - ALFIN", utilizado na Espanha e em alguns países latinos e "Literacia da Informação" em Portugal. No Brasil já utilizou-se "information literacy", "alfabetização informacional", "habilidade informacional", "competência informacional" e "letramento informacional".

Gasque (2010), afirma que embora esses conceitos estejam relacionados entre si, não devem ser empregados como sinônimos, uma vez que representam ações, eventos e ideias diferentes. Neste sentido, propõe um arcabouço conceitual para o letramento informacional, ainda que em "natureza incipiente de esboço", como a própria autora define, baseado na literatura da área educacional. Conforme este arcabouço, apresenta os seguintes conceitos:

a) Alfabetização Informacional: primeira etapa do processo de letramento. Envolve o conhecimento básico dos suportes de informação, compreensão de conceitos relacionados à busca e ao uso da informação, domínio das funções básicas do computador;

b) Competência Informacional: expressão do "saber fazer". Derivada das relações entre o conhecimento que o sujeito detém, experiência adquirida e reflexão sobre a ação;

c) Habilidades Informacionais: Realização de cada ação específica e necessária para alcançar determinada competência.

d) Letramento Informacional: $O$ engajamento do sujeito nesse processo de aprendizagem a fim de desenvolver competências e habilidades necessárias à busca e ao uso de informação de modo eficiente e eficaz. Processo de aprendizagem contínua e prolongada ao longo da vida.

Deste modo, para fins deste estudo, será adotado como tradução para "information literacy" o termo letramento informacional, expressão de um processo de aprendizagem contínuo, cujo conceito, conforme Dudziak (2003) tem como principais componentes de sustentação:

- O processo investigativo;

- O aprendizado ativo;

- O aprendizado independente;

- O pensamento crítico;

- O aprender a aprender;

- O aprendizado ao longo da vida. 
Ainda neste âmbito, Catts e Lau (2008), afirmam que o letramento informacional é a capacidade que as pessoas possuem para:

- Reconhecer suas necessidades de informação;

- Localizar e avaliar a qualidade da informação;

- Armazenar e recuperar informação;

- Fazer uso eficaz e ético da informação; e

- Aplicar a informação para criar e comunicar conhecimento.

Considerando a relevância do tema, organismos internacionais e entidades de classe, notadamente reconhecidas e importantes de todo o mundo, apresentaram nos últimos anos, geralmente na ocasião da realização de Congressos, Seminários ou reuniões, diretrizes e orientações relacionadas ao letramento informacional, que figuram em diversas declarações e proclamações acerca da temática, conforme quadro abaixo:

\begin{tabular}{|l|l|}
\hline \multicolumn{1}{|c|}{ Documento } & Ano \\
\hline $\begin{array}{l}\text { Declaração de Praga: Rumo a uma sociedade alfabetizada em } \\
\text { informação }\end{array}$ & 2003 \\
\hline $\begin{array}{l}\text { Declaração de Alexandria sobre letramento informacional e } \\
\text { aprendizagem ao longo da vida }\end{array}$ & 2005 \\
\hline Declaração de Lima & 2009 \\
\hline $\begin{array}{l}\text { Declaração de Toledo sobre alfabetização informacional: } \\
\text { bibliotecas pela aprendizagem permanente }\end{array}$ & 2009 \\
\hline \begin{tabular}{l} 
Declaração de Maceió sobre competência em informação \\
\hline Declaração de Féz sobre Mídia e Alfabetização Informacional
\end{tabular} & 2011 \\
\hline $\begin{array}{l}\text { Declaração de Havana: 15 anos de competência em informação } \\
\text { Declaração de Moscou sobre Alfabetização Informacional e } \\
\text { Midiática }\end{array}$ & 2012 \\
\hline $\begin{array}{l}\text { Manifesto de Florianópolis sobre a competência em informação } \\
\text { e as populações vulneráveis e minorias }\end{array}$ & 2013 \\
\hline Carta de Marília & 2014 \\
\hline
\end{tabular}

Quadro 1: Declarações e Recomendações sobre Letramento Informacional Fonte: Elaboração Própria 
A Declaração de Praga (2003) e a Declaração de Alexandria são considerados dois documentos-chave sobre Letramento Informacional e ambos o identificam como um direito humano básico, além de ressaltar sua relevância para uma efetiva participação na Sociedade da informação. Ademais, várias questões são abordadas reiteradamente, em praticamente, todas as Declarações, destacando-se:

a) O letramento informacional como pré-requisito para a aprendizagem permanente/ao longo da vida e a formação de aprendizes autônomos e usuários eficazes da informação;

b) A importância do desenvolvimento de competências e habilidades relacionadas ao manejo e uso das tecnologias de informação e comunicação (TICs);

c) Recomendações aos governantes para o desenvolvimento e implementação de programas de letramento informacional em nível local, regional e nacional;

d) O letramento informacional como uma preocupação que deve ser de todos os setores da sociedade, adaptando-se a contextos específicos;

e) O acesso e uso eficaz da informação como instrumento para a redução das desigualdades;

f) Estabelecimento de agenda local e/ou internacional para o desenvolvimento do letramento informacional;

g) Conclamação da participação de bibliotecas, bibliotecários, instituições de classe e recomendação de cooperação entre instituições e profissionais para o trabalho em prol do letramento informacional;

h) O letramento informacional e sua importância para a participação efetiva na democracia e o pleno exercício da cidadania.

Ou seja, o conceito reflete o uso eficaz da informação para o aprendizado permanente, ou ao longo da vida. Deste modo, a American Association of School Librarians (AASL), ao definir os parâmetros para o aprendiz do século 21, apresenta alguns fatores que determinam a formação desse aprendiz: a leitura, como uma janela para o mundo; a investigação, que proporciona uma estrutura para a aprendizagem; a atitude ética no uso da informação, que deve ser ensinada; as competências tecnológicas, cruciais para as exigências do mercado de trabalho; o acesso democrático, componente chave na educação. A partir desta estrutura de formação, os aprendizes são capazes de utilizar competências, recursos e ferramentas para:

a) investigar, pensar criticamente e adquirir conhecimento;

b) tirar conclusões, tomar decisões embasadas, aplicar o conhecimento adquirido a 
novas situações e gerar novos conhecimentos;

c) compartilhar conhecimento e atuar de modo ético e produtivo, como membros de uma sociedade democrática;

d) buscar aprimoramento pessoal e estético.

Apesar de constituir-se como elemento essencial no contexto educacional, cabe ressaltar que o letramento informacional não se restringe a este cenário e também é vital "no contexto do trabalho, da sociedade civil, da saúde e do bem-estar", conforme prevê a Declaração de Alexandria (2005).

O letramento informacional tem, atualmente, um papel fundamental na agenda de desenvolvimento e no combate à exclusão social, o que amplia o seu escopo, não mais visto, apenas, como uma experiência individual. Para a compreensão do letramento informacional hoje nós temos que incluir não apenas a avaliação e uso de fontes de informação ou da biblioteca, mas também questões de política social, relativas à diminuição da desigualdade, o desenvolvimento de competências para uma sociedade pós-industrial, o pensamento crítico e a aprendizagem ao longo da vida. Além disso há também a questão da alfabetização digital, currículos escolares e do ensino superior, os primeiros anos de aprendizagem, problemas de saúde, a dinâmica do local de trabalho e de ensino e aprendizagem de competências e estratégias que dão uma ênfase crescente ao ensino e à aprendizagem em situações informais (CRAWFORD, 2013).

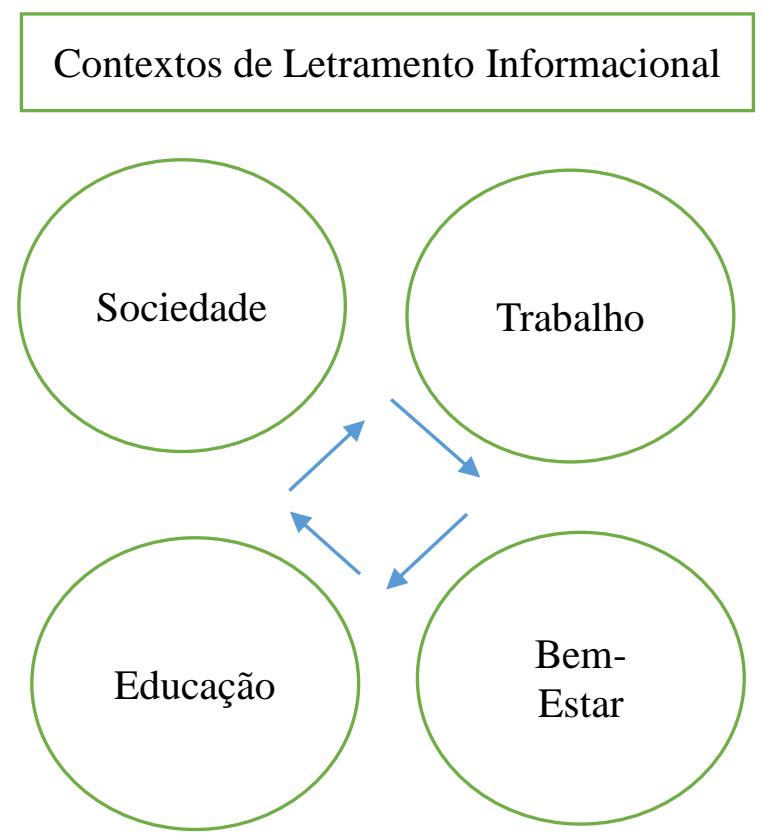

Figura 4: Contextos de Letramento Informacional

Fonte: Catts e Lau (2008) 
Conforme expresso na Figura 4, o letramento informacional não é apenas uma experiência individual, mas social, que se dá em diversos contextos. Envolve o pensamento crítico, a resolução de problemas e o aprendizado ao longo da vida, em contextos variados como a sociedade, educação, trabalho e bem-estar.

\subsubsection{Letramento Informacional e Sociedade da Informação}

A Sociedade da Informação, Sociedade do Conhecimento, ou Sociedade Informacional, termo adotado por Castells (2003, p.65), indica "uma forma específica de organização social em que a geração, o processamento e a transmissão da informação tornam-se as fontes fundamentais de produtividade e poder devido às novas condições tecnológicas surgidas nesse período histórico".

Este novo paradigma técnico-econômico, é um fenômeno global, com grande potencial transformador das atividades sociais e econômicas, com proeminente dimensão político-econômica e marcado pela influência da infraestrutura informacional para que as regiões sejam mais ou menos atraentes a investimentos, destacando-se ainda sua acentuada dimensão social, por reduzir distâncias entre pessoas, aumentar seu nível de informação e fomentar a formação de redes (LIVRO VERDE DA SOCIEDADE DA INFORMAÇÃO NO BRASIL, 2000).

Vários são os desafios trazidos pela nova ordem social, que impactam em todos os setores da sociedade e da vida dos indivíduos. Neste contexto, o Livro Verde da Sociedade da Informação no Brasil, apresenta, entre outros, os desafios voltados para a educação: uma vez que educar em uma Sociedade da Informação significa muito mais que capacitar as pessoas para o uso das tecnologias de informação e comunicação, trata-se de investir no desenvolvimento de competências suficientemente amplas para que possam participar ativamente na produção de bens e serviços, tomar decisões fundamentadas no conhecimento, operar com fluência os novos meios e ferramentas de trabalho, bem como aplicar criativamente as novas mídias. De forma mais abrangente trata-se de formar os indivíduos para "aprender a aprender", para que sejam capazes de lidar com as transformações contínuas de base tecnológica e social.

Neste sentido, emerge a importância do letramento informacional, que em conjunto com o acesso à informação e uso efetivo de tecnologias da informação e 
comunicação, desempenha um papel fundamental na formação das competências necessárias para a sobrevivência na sociedade da informação. O letramento informacional exerce uma função de liderança na redução das desigualdades entre países e povos e na promoção da tolerância e compreensão mútua em contextos multiculturais e multilíngues (DECLARAÇÃO DE PRAGA, 2003).

A convergência de tecnologias, ferramentas, acessibilidade e necessidades sociais o torna indispensável na Sociedade da Informação (DEMASSON; PARTRIDGE; BRUCE, 2010). Além disso, os indivíduos estão, cada vez mais, expostos a um grande volume de informação, sendo imprescindível o desenvolvimento de competências e habilidades informacionais para a localização, avaliação e uso crítico e ético da informação em diversos contextos, para a tomada de decisões, resolução de problemas, engajamento no processo de aprendizagem, participação democrática e pleno exercício da cidadania.

Conforme Suaiden (2012), um dos maiores desafios da sociedade da informação é a inclusão social, uma vez que a pessoas marginalizadas muitas vezes não sabem sequer de que informação necessitam ou quando necessitam, tornandose dependentes da informação oral e sendo manipulados na busca da informação. Neste sentido, destaca-se o papel do letramento informacional, na medida que pode "colaborar, definitivamente, para acabar com problemas de desigualdades sociais, proporcionar a geração de emprego e renda, capacitar e melhorar a formação de investidores e aumentar a produção científica".

Além disso, consoante ao aumento da inclusão, outros indicadores emergem, tais como a diminuição da violência e a geração de oportunidades de desenvolvimento para as pessoas marginalizadas. Desta forma, o acesso às novas tecnologias de comunicação e informação, a produção de conteúdos, a melhoria da infraestrutura informacional (biblioteca públicas, escolares, universitárias, etc.), a aplicação de metodologias de letramento informacional e a consciência do significado da melhoria da qualidade de vida devido à participação efetiva na sociedade da informação são questões pertinentes a serem consideradas (SUAIDEN, 2012).

Suaiden (2000, p. 60) destaca ainda o papel da biblioteca pública neste contexto, uma vez que:

À medida que a biblioteca pública se vincular adequadamente com a comunidade, ela passará a ser o caminho que possibilitará a participação efetiva na sociedade da informação. Isso é de extraordinária importância em um país onde a desinformação atinge 
altas proporções, e, sem essa oportunidade, milhares de pessoas jamais terão oportunidade de entender e de ter noção dos seus direitos e deveres em uma sociedade globalizada, pois o acesso à informação, nos novos tempos, significa o investimento adequado para diminuir as desigualdades sociais e as formas de dominação que foram dominantes na história contemporânea.

Observa-se, deste modo, estreito relacionamento entre as duas temáticas, uma vez que a sociedade da informação, com seu novo modus operandi e suas novas exigências, é o contexto de onde emergiu o letramento informacional. Este por sua vez, tornou-se um item indispensável e crucial para a sobrevivência e efetiva participação na sociedade da informação, desempenhando um papel decisivo nos processos inclusivos e participativos.

\subsubsection{Modelos e Abordagens}

Abaixo são apresentados alguns modelos e abordagens relacionados ao letramento informacional. Cabe ressaltar que a relação abaixo não é e não tem a pretensão de ser exaustiva. O objetivo é apresentar alguns modelos e abordagens existentes a fim de selecionar aqueles que melhor se encaixam para a compreensão da questão de pesquisa deste estudo.

\subsubsection{Information Search Process - ISP de Carol Kuhlthau}

O Modelo Information Search Process - ISP ou Processo de Busca de Informação (KUHLTHAU, 1991), quadro 2, foi desenvolvido pela pesquisadora Carol Kuhlthau, sob a ótica construtivista do aprendizado, após uma série de estudos sobre a experiência e o comportamento dos usuários na busca da informação. Os estudos de Kuhlthau enquadram-se no paradigma cognitivo, que faz parte das abordagens alternativas dos estudos de usuários, onde prevalece o foco nos usuários e suas interações com o meio em que está inserido. 


\begin{tabular}{|l|l|l|l|l|l|l|}
\hline $\begin{array}{l}\text { Estágios/ } \\
\text { Tarefas }\end{array}$ & Iniciação & Seleção & Exploração & Formulação & $\begin{array}{l}\text { Coleta de } \\
\text { informações }\end{array}$ & Apresentação \\
\hline $\begin{array}{l}\text { Sentimentos } \\
\text { (aspectos } \\
\text { afetivos) }\end{array}$ & Incerteza & Otimismo & $\begin{array}{l}\text { Confusão, } \\
\text { frustração, } \\
\text { Dúvida }\end{array}$ & Clareza & $\begin{array}{l}\text { Senso de } \\
\text { direção, } \\
\text { confiança }\end{array}$ & $\begin{array}{l}\text { Alívio, } \\
\text { Satisfação ou } \\
\text { Insatisfação }\end{array}$ \\
\hline $\begin{array}{l}\text { Pensamentos } \\
\text { (aspectos } \\
\text { cognitivos) }\end{array}$ & \multicolumn{5}{|c|}{ Ambiguidades------------------------------------ Especificidades } \\
\hline $\begin{array}{l}\text { Ações } \\
\text { (aspectos } \\
\text { Físicos }\end{array}$ \\
\hline
\end{tabular}

Quadro 2: Modelo ISP - Processo de Busca de Informação

Fonte: KUHLTHAU, 1991

O modelo reflete o aprendizado por meio da pesquisa e tem influenciado e embasado estudos e práticas relacionadas ao letramento informacional, uma vez que fornece uma base para a compreensão e análise do comportamento dos usuários na busca pela informação. Para sua construção, a autora considerou os aspectos cognitivos e afetivos dos usuários durante todo o processo de busca da informação e embasou-se teoricamente nos trabalhos de Kelly (1963) teoria da construção pessoal, Taylor (1963;1986) níveis de necessidades de informação, Belkin (1982) estado anômalo do conhecimento e Dervin (1986) abordagem sense making.

O ISP caracteriza o processo de busca da informação em seis estágios: Iniciação, Seleção, Exploração, Formulação, Coleção e Apresentação (Kuhlthau, 1991), conforme descritos abaixo:

1- O primeiro estágio, a Iniciação se dá quando o usuário toma consciência de uma lacuna em seu conhecimento, diante da necessidade de resolver um problema ou desenvolver um projeto ou pesquisa. Nessa fase o usuário experimenta e expressa sentimentos de insegurança e apreensão, associados a pensamentos vagos e ambíguos.

2- No segundo estágio, denominado Seleção, o objetivo é identificar e selecionar a área ou tema a ser investigado. Nesta etapa continuam a ocorrer sentimentos de incerteza, cedendo espaço, em alguns casos, a uma breve sensação de otimismo após a seleção do tópico a ser investigado, momento no qual há prontidão para iniciar a pesquisa.

3- A próxima etapa é a Exploração, caracterizada por sentimentos de confusão, 
incerteza e dúvida, frequentemente é a fase mais difícil para os usuários. A atividade principal é buscar informação sobre o tópico geral escolhido para ampliar o entendimento pessoal sobre a questão.

4- Na quarta etapa, a Formulação, o sentimento de incerteza diminui à medida que a compreensão aumenta, gerando sentimento de confiança e clareza de pensamento. A atividade deste estágio é estabelecer um foco para o seu problema, a fim de orientar a busca.

5- Coleção é o quinto estágio do processo, quando ocorre uma interação mais efetiva entre usuário e sistema de informação. Neste ponto, a tarefa é reunir informações pertinentes para o problema em foco. Sentimentos de confiança e senso de direção estão presentes neste estágio.

6- A sexta etapa é a Apresentação, quando o objetivo é completar a busca e resolver o problema. Sentimento de alívio é comum, bem como sentimento de satisfação caso a atividade de pesquisa tenha sido bem-sucedida, ou de desapontamento em caso contrário.

Conforme Kuhlthau (1999), as pessoas experimentam o processo de busca de informação de forma holística, como "um jogo de pensamentos, sentimentos e ações". Seus estudos foram os primeiros a investigar os aspectos afetivos, ou os sentimentos dos usuários, no processo de busca de informações, juntamente com os aspectos cognitivos e físicos mais comumente estudados.

Com a evolução de seus estudos a autora percebeu que, à medida que os usuários adquirem mais maturidade intelectual e experiência, inclusive no uso da biblioteca e das fontes de informação, suas percepções sobre o processo de busca de informação sofrem alterações importantes, embora os estágios do processo continuem os mesmos (KUHLTHAU, 1999).

\subsubsection{Abordagem relacional: As sete faces do letramento informacional de Bruce}

Bruce (1997), define o letramento informacional como uma "habilidade genérica" muito importante para que as pessoas possam lidar de forma eficaz com a tomada de decisões, a resolução de problemas ou a pesquisa e serem responsáveis por sua própria formação e aprendizado ao longo da vida de acordo com seus interesses pessoais e profissionais. A pesquisadora australiana utilizou a fenomenografia para identificar diferentes formas com que as pessoas experimentam 
o letramento informacional. As diferentes faces do letramento informacional que formam o modelo de Bruce foram extraídas da experiência de professores universitários de duas universidades da Austrália. O resultado são sete concepções, faces ou modos de experimentar o letramento informacional.

Conforme Bruce (1997), enquanto fenômeno, o letramento informacional inclui toda uma gama de experiências e os usuários precisam ser capacitados para obter experiência em todas as suas formas. Também é necessário, segundo Bruce, refletir sobre as variações nas experiências e entender que formas de letramento informacional são relevantes para situações diferentes. A aprendizagem do letramento informacional pode ser vista, então, como uma forma de experimentar o uso da informação de todas estas formas diferentes.

As descrições dessas concepções revelam variações nas formas com que os indivíduos interagem com a informação e o sentido do letramento informacional é proveniente dessas interações. Deste modo, as sete formas de experimentar o letramento informacional, conforme o modelo de Bruce são:

1- A concepção baseada nas tecnologias de informação: No centro dessa concepção está a importância das tecnologias de informação e comunicação para o acesso e uso da informação. Esta forma de experimentar o letramento informacional depende da disponibilidade e da capacidade de uso das TICs.

2- A concepção baseada nas fontes de informação: Aqui a experiência do letramento informacional passa pelo conhecimento das fontes de informação e pelas habilidades em acessá-las de forma independente. Envolve o conhecimento de fontes em variados formatos, incluindo as eletrônicas e as pessoas, uma vez que é o conhecimento que torna possível a recuperação das informações contidas nas fontes. A experiência baseada nas fontes subdivide-se em três categorias: conhecer as fontes e suas estruturas, conhecer as fontes de informação e usá-las com independência, conhecer as fontes de informação e usá-las com flexibilidade, seja de forma independente ou por mediação.

3 - A concepção baseada na informação como processo: O letramento informacional vivenciado como um processo, envolvendo desde o reconhecimento da necessidade, até a busca e o uso da informação. O resultado da experiência é uma ação eficaz, um problema resolvido ou uma decisão tomada.

4- A concepção baseada no controle da informação: Nesta experiência o letramento informacional é considerado instrumento para o controle da informação. 
Neste contexto, as pessoas letradas em informação são aquelas capazes de utilizar vários meios para trazer as informações de que precisa, dentro de sua esfera de influência, de forma a recuperá-las e manipulá-las facilmente quando for necessário.

5- A concepção baseada na construção do conhecimento: O uso da informação está no centro desta concepção, que envolve a construção de uma base pessoal de conhecimento, ou seja, vai além do mero armazenamento de informação. É alcançada a partir da avaliação crítica das informações.

6- A concepção baseada na extensão do conhecimento: O uso da informação segue, sendo também, o centro da atenção nesta concepção, não mais centrado na construção do conhecimento, mas em sua extensão. Envolve intuição e criatividade para gerar novos pontos de vista, a partir da experiência pessoal com a informação.

7- A concepção baseada no saber ou sabedoria: Relaciona-se ao uso "sábio" da informação, baseado em valores, atitudes e crenças pessoais. Implica relacionar a informação a um contexto mais amplo, levando em conta aspectos históricos e socioculturais. A utilização sábia da informação pode ocorrer em vários contextos e situações, como na emissão de opiniões, na tomada de decisão e na pesquisa.

O modelo de Bruce propõe uma abordagem relacional e oferece uma compreensão alternativa ao modelo comportamental do letramento informacional. Nesta perspectiva o letramento informacional é visto como um conjunto complexo de experiências e concepções relacionadas ao uso da informação, que pode ser vivenciado e experimentado de diferentes formas e em contextos múltiplos.

\subsubsection{Abordagem Crítica e Contextos do Letramento Informacional}

O conceito tradicional de letramento informacional, entendido como um conjunto de habilidades cognitivas para a busca e o uso da informação, vem sendo questionado por alguns autores, que apontam suas deficiências e propõem a expansão do conceito e a adoção de abordagens alternativas para o letramento informacional. É o caso de pesquisadores como Elmborg (2006) e Hall (2009) que utilizam elementos e autores da pedagogia crítica, como Paulo Freire e John Dewey para propor uma "critical information literacy" ou letramento informacional crítico (tradução nossa). É o caso também de Lloyd (2005; 2010), que defende "information literacy landscapes", contextos de letramento informacional ou paisagens de letramento informacional (tradução nossa), e sugere uma visão contextualizada do 
letramento informacional, utilizando uma perspectiva sociocultural.

Elmborg (2006), critica as definições de letramento informacional adotadas pela ACRL e pela bibliografia de biblioteconomia, por omitir-se em questões centrais que afetam estudantes, docentes, comunidades e bibliotecas. Elmborg (2006) cita Nogaars (2003), ao fazer um apelo para que as bibliotecas participem do movimento do letramento informacional, distanciando-se das definições instrumentais baseadas em habilidades, buscando uma compreensão do letramento informacional como um fenômeno "culturalmente situado" baseado no modo como as comunidades constroem significado e ideia de pertencimento.

Como alternativa ao conceito tradicional o autor propõe uma reflexão, com base nas teorias críticas da pedagogia, e a inclusão do elemento crítico ao conceito de letramento informacional. Para Elmborg (2006), as bibliotecas e os bibliotecários devem centrar-se menos na transferência do conhecimento, e preocupar-se mais com a formação da consciência crítica das pessoas, a partir da qual é possível formar agentes ativos, capazes de formular e responder questões que os afetam diretamente ou ao mundo à sua volta. Em última instância, Elmborg (2006), afirma que para chegar a uma "critical information literacy" é essencial o "desenvolvimento de uma consciência crítica sobre as informações, aprender a fazer perguntas sobre o papel da biblioteca na estruturação e apresentação de uma única realidade cognoscível".

Ou seja, a questão permeia, também, reflexões profundas sobre o papel educativo da biblioteca e do bibliotecário, que devem pensar criticamente e questionar sua formação e suas práticas. Conforme o autor, a partir dessa mudança de postura os bibliotecários deixam de estudar a biblioteca como matéria, e convertem-se em especialistas em treinamento e crescimento intelectual e crítico. Mas só podem ajudar a realizar a "viagem" ou a percorrer o "caminho" do crescimento intelectual se eles mesmos forem capazes de fazê-lo, daí a importância de repensar a formação do bibliotecário.

Portanto,

O trabalho fundamental das bibliotecas em relação ao letramento informacional não se trata de defini-lo ou descrevê-lo, mas de desenvolver uma prática crítica da biblioteconomia, uma práxis fundamentada teoricamente. Esta evolução filosófica é fundamental para que bibliotecas e bibliotecários sejam conscientes de todo potencial inerente ao letramento informacional e possam alinhar os valores da alfabetização crítica ao trabalho diário nas bibliotecas (Elmborg, 2006) (tradução livre da autora). 
Hall (2009), se apoia nas ideias expostas por Elmborg (2006) e nas teorias educacionais de John Dewey e Paulo Freire, e também propõe uma "critical information literacy", invocando bibliotecários a irem além do ensino de habilidades informacionais e tecnológicas e encorajando o desenvolvimento de um letramento informacional em ação, baseado no que Paulo Freire chamou de "práxis".

Para Hall (2009), os bibliotecários não devem pensar o letramento informacional como um processo neutro ou fora de contexto, nem nos usuários simplesmente como "depósitos" de competências informacionais e que respondem da mesma forma ao mesmo estímulo. Devem, por outro lado, depois de terem introduzido em suas comunidades novos modos de armazenamento, recuperação e criação de informação, levantar problemas e agir sobre o mundo, a fim de mudá-lo. Deste modo, devem buscar se engajar com a sua comunidade para resolver problemas e buscar soluções, utilizando o letramento informacional de forma crítica e contextualizada, voltada para a práxis, ou seja, para a ação.

Buscando uma redefinição do conceito, Lloyd (2005; 2010) sugere uma desconstrução do discurso, de modo a construir uma visão holística, um conceito mais amplo, para além da estrutura formal, levando em conta o contexto, de modo "a ampliar o conhecimento das múltiplas realidades da vida cotidiana, que são aumentadas pelo acesso efetivo, mas diverso à informação". Ou seja, amplia o intento do letramento informacional e o traz para outros contextos, como o ambiente de trabalho e a vida comunitária, onde o acesso à "informação social" permite um "aprendizado personificado". Configura-se, portanto, em atividade colaborativa e social, dependente de relacionamentos pessoais e comunitários.

Neste sentido, o que se torna importante é a compreensão das fontes formais, informais, sociais e personificadas de informação disponíveis ao aprendiz. É necessário reconhecer influências sociais, políticas e históricas dos discursos que permitem que a informação seja acessada, utilizada e avaliada, e é importante entender o modo que participantes dentro do discurso influenciam e mediam o acesso a informação, por meio do discurso prático, aos locais de conhecimento acordado (LLOYD, 2005).

A autora defende ainda que o paradigma dominante do letramento informacional enfatiza a importância de conectar-se com a informação textual e isso produz um modelo deficiente que não leva em conta a importância do aprendizado informal ou outras fontes de informação que são acessadas pela comunicação ou pela 
ação. Isso reduz o poder do letramento informacional e explica o modo pelo qual é subestimado pelas pessoas, além de reduzir, também, a capacidade de transferir habilidades e práticas entre contextos.

Lloyd (2005) sugere que pode ser problemático para a causa apresentar uma única concepção de verdade. Por isso, afirma, é imprescindível desenvolver maneiras de explorar o letramento informacional que permitam o desenvolvimento de um conceito mais amplo que atinja os interesses da educação, local de trabalho e comunidade. Deste modo, será possível construir um quadro genérico de habilidades (relacionando aprendizado textual, social e corpóreo) e competências que possam ser ensinadas em diversos cenários, de modo a facilitar o desenvolvimento de habilidades e competências que permitam e enriqueçam o aprendizado ao longo da vida.

A possibilidade de ouvir outras vozes, além da educacional, sobre o letramento informacional expande as possibilidades de conceituação do letramento informacional e de qual é e deve ser o seu papel. Permite dessa forma, entender o letramento informacional como uma "meta-competência", ou seja, uma série de competências que permitem novas habilidades e conhecimentos em uma variedade de contextos (KEARNS, 2001 apud LLOYD, 2005).

Os preceitos defendidos por Elmborg, Hall e Lloyd guardam semelhanças entre si, por proporem abordagens alternativas para a compreensão do fenômeno. Os três autores buscam uma redefinição do conceito de letramento informacional, compreendido de uma perspectiva holística como uma prática cultural e socialmente contextualizada.

\subsection{BIBLIOTECAS PÚBLICAS E O LETRAMENTO INFORMACIONAL}

Esta seção faz uma revisão dos principais elementos identificados na literatura que envolvem o letramento informacional e as bibliotecas públicas: a evolução do papel educativo da biblioteca, aspectos que envolvem o acesso às tecnologias e inclusão digital, cooperação e parcerias com outras instituições, aspectos favoráveis e dificuldades e desafios enfrentados pelas bibliotecas públicas no desenvolvimento do letramento informacional e por fim, o papel do bibliotecário como agente de letramento informacional nas bibliotecas públicas. 


\subsubsection{O papel educativo}

A biblioteca pública é o ponto de acesso, principal e dinâmico, da comunidade, estruturado para responder de modo proativo a uma multiplicidade de necessidades de informação que estão sempre em mudança (KOONTZ; GUBBIN, 2012). A biblioteca pública desempenha no escopo de suas finalidades diversas funções na comunidade, relacionadas ao seu papel social, cultural, informativo e educativo.

A função educativa não é um novo papel para a biblioteca pública, que sempre ocupou um lugar na educação desde o seu início, como um mecanismo para promover hábitos de leitura nas classes trabalhadoras urbanas no século XIX. Foi também nesta época, durante o movimento da biblioteca pública nos Estados Unidos, que surgiu o "serviço de referência", quando o acesso às bibliotecas se democratizou devido ao aumento nos níveis de alfabetização da população. Accart $(2012$, p.7) cita as quatro missões do profissional de referência, definidas por S.S. Green em 1876, onde já se percebe o cunho educativo da biblioteca e do bibliotecário, quais sejam: "ajudar os usuários a compreender o funcionamento da biblioteca; responder às perguntas dos usuários; ajudar os usuários a selecionar as obras boas; promover e personalizar os serviços da biblioteca".

Conforme Campello (2009), o trabalho de referência é definido por alguns autores como ação educativa do bibliotecário, que vai além da mera orientação para localizar informações, uma vez que propicia a interação bibliotecário-usuário. Deste modo, concede ao bibliotecário, enquanto mediador, oportunidade para responder às necessidades informacionais dos usuários, caracterizando desta forma, um processo de intervenção didática.

No entanto, o fato de o trabalho de referência ser um trabalho realizado por demanda, com o atendimento aos usuários que buscavam ajuda do bibliotecário e a necessidade de encontrar novas maneiras de atender às demandas informacionais de uma clientela que se expandia em busca de educação formal, levou ao aparecimento da educação de usuários, serviço por meio do qual a biblioteca atinge número maior de usuários, ao mesmo tempo em que procura satisfazer mais especificamente a suas necessidades de informação. Assim, a educação de usuários ampliou a ação educativa da biblioteca, pois, diferentemente do trabalho de referência, este tem característica proativa, atendendo aos usuários com cursos, visitas guiadas e outras ações planejadas de ensino do uso da biblioteca e de seus recursos 
(CAMPELLO, 2009)

Gomez-Hernandez e Pasadas-Ureña (2007) afirmam que, a necessidade de repensar sua missão, metas e objetivos de seus serviços fez com que o tradicional serviço de formação de usuários nas bibliotecas públicas evoluísse. Antes centrado apenas no uso adequado das instalações e equipamentos da biblioteca e nos recursos de informação impressos, o serviço evoluiu para a realização de programas de Letramento Informacional, voltados a diferentes grupos, com a finalidade de que adquiram as competências necessárias para buscar e utilizar a informação em todos os suportes, canais e localizações, de acordo com suas necessidades. Os autores consideram que esta evolução é uma adaptação às novas circunstâncias e exigências do serviço. No entanto, ponderam que um programa de Letramento Informacional deve contemplar, também, as atividades de formação de usuários tradicionais (visitas guiadas, guias de uso de recursos, assistência personalizada), mas de modo que se integrem aos "novos e mais amplos objetivos de aprendizagem", incorporando as atividades de formação da biblioteca ao ambiente educativo formal e informal da comunidade a que serve.

Portanto, o que ocorre não é o surgimento de novo papel, mas uma renovação deste papel diante das novas exigências do atual contexto. Na Sociedade da Informação o papel educativo da biblioteca pública está voltado para a aprendizagem ao longo da vida, promoção da educação e do letramento informacional (POUSTIE, 2009).

Para Gasque (2012), as bibliotecas devem ir além do paradigma de acesso à informação para um paradigma pedagógico, ou seja, mais que disponibilizar informação é preciso "envolver a comunidade em programas que possibilitem buscar, decodificar, interpretar e transformar as informações em conhecimento a favor da vida". Defende ainda que, as bibliotecas (não apenas escolares e acadêmicas, mas também as públicas e especializadas) devem converter-se em "Centros de Recursos de Aprendizagem", que consiste nos seguintes elementos:

a) Multiusabilidade: espaços com layout apropriado, com disponibilização de vários recursos simultaneamente;

b) Favorecimento da socialização;

c) Integração do planejamento com a coordenação/assessoria pedagógica;

d) Formação contínua dos profissionais;

e) Caráter pedagógico cultural. 
A responsabilidade e o compromisso das bibliotecas públicas com o letramento informacional e a aprendizagem ao longo da vida, refletem e figuram em suas diversas declarações de missão e planos estratégicos (GOMEZ-HERNANDEZ; PASADAS-UREÑA, 2007; HARDING, 2008).

No Manifesto da Unesco sobre Bibliotecas Públicas (IFLA/UNESCO, 1994), essa questão fica clara ao serem apresentadas as missões da biblioteca pública, que dentre outras destacam-se as seguintes, que reforçam o papel educativo da biblioteca pública e seu compromisso com a aprendizagem permanente: "apoiar tanto a educação individual e de iniciativa própria quanto a educação formal em todos os níveis"; "facilitar o desenvolvimento da capacidade de utilizar a informação e a informática"; e "apoiar, participar e, se necessário, criar programas e atividades de alfabetização para todos os diferentes grupos etários".

Em 2009 a IFLA/UNESCO produziu recomendações adicionais em complementação ao Manifesto, e o compromisso com o aprendizado contínuo é reafirmado de forma bastante clara, ao recomendar que as Bibliotecas Públicas devem "conectar nossas comunidades e educar e capacitar as pessoas onde isso for necessário. Os bibliotecários e cientistas da informação podem agir como educadores e consultores pessoais em matéria de conhecimentos e não somente como chaveiros ou porteiros da internet".

\subsubsection{Inclusão Digital e Letramento Informacional}

O Manifesto sobre a Internet (IFLA/UNESCO, 2002), estabelece que as bibliotecas têm "a responsabilidade de facilitar e promover o acesso público à informação de qualidade e à sua comunicação". E ainda que "devem ser oferecidos aos usuários a orientação necessária e o ambiente adequado para que eles possam usar, com liberdade e confiança, as fontes e os serviços de informação de sua escolha. " E por fim, enfatiza o papel educativos dos bibliotecários, responsáveis por "prover as informações e os recursos para que os usuários aprendam (grifo nosso) a utilizar a Internet e a informação eletrônica eficazmente".

Destaca-se, portanto, o papel das bibliotecas públicas não apenas na disponibilização de acesso às Tecnologias de Informação e Comunicação (TICs), mas também no desenvolvimento de competências e habilidades para que os usuários possam acessar esses recursos e utilizá-los para buscar, localizar e usar a informação. 
Deste modo, presta importante contribuição para a inclusão digital, à medida que além de fornecer o acesso, desenvolve competências para o seu uso efetivo, em prol da cidadania e melhoria da qualidade de vida.

Atualmente, a informação, na maioria dos casos, pode ser facilmente recuperada por meio da internet, mas as pessoas gastam um valioso tempo por falta de competências adequadas para identificar os recursos adequados e para encontrar, avaliar e utilizar a informação de forma eficaz na resolução de problemas. (BADKE, 2008 apud LAI, 2011).

Neste sentido, POUSTIE (1999) apresenta a experiência da Biblioteca e Centro de Informação e Tecnologia Mirrabooka, localizada na cidade de Stirling, na Austrália. A Biblioteca foi instalada numa área de vulnerabilidade social, marcada por problemas de segurança pública e transformou a realidade local, tornando-se um "centro social da comunidade", um "catalisador para a aprendizagem ao longo da vida" e uma "agência de treinamento" para capacitar as pessoas a utilizarem as novas tecnologias, em especial a Internet. A Biblioteca Mirrabooka foi planejada para ser um espaço comunitário, para abrigar salas de reuniões, um centro de informações, um centro de tecnologia da informação e um Café no hall de entrada. A biblioteca oferece à comunidade acesso gratuito à internet, cuja maioria não tinha em casa. O Centro iniciou suas atividades com a oferta dos seguintes cursos: Introdução à internet; Noções básicas de internet; Pesquisar na internet de forma eficaz; Usando o correio eletrônico de forma eficaz. Em seguida expandiu a oferta e passou a oferecer também cursos de Genealogia na net e Recursos de Saúde na Rede. Oferecia ainda treinamentos em Word, Excel, etc.

A inclusão do Centro de Tecnologia da Informação na Biblioteca é fruto da concepção de que é papel das bibliotecas públicas não apenas fornecer acesso à rede, mas ensinar as pessoas como obter o máximo a partir dela, a avaliar e usar informações que acessem de modo consciente e ético (POUSTIE, 1999).

Em adição ao fornecimento de acesso gratuito à internet, serviço comumente ofertado por bibliotecas públicas ao redor do mundo, muitas bibliotecas têm implementado programas de treinamento para utilização das TICs, assim como na experiência da Mirrabooka citada anteriormente.

Para Harding (2008) parece ser nessa área que as bibliotecas públicas mais fizeram incursões relacionadas ao letramento informacional, pois de nada adianta ofertar recursos tecnológicos, se os indivíduos não possuem habilidades para acessá- 
los ou usá-los eficazmente. A autora cita iniciativas de bibliotecas públicas que desenvolveram programas voltados para grupos específicos, como treinamento em TICs para idosos e grupos minoritários (na Noruega), treinamento para o uso de recursos eletrônicos da biblioteca, como bases de dados e sites específicos (Canadá), oferta de cursos de habilidades computacionais básicas (na Austrália). Outras bibliotecas vão além e expandem o treinamento para a avaliação dos recursos, geralmente em conjunto com o treinamento em internet: uso inteligente de internet (na Espanha), usando a internet eficazmente (na Austrália), avaliação crítica do conteúdo on line (nos Estados Unidos). Harding (2008) afirma ainda que os benefícios desses cursos e aulas vão além dos pequenos grupos que deles participam, uma vez que os participantes usam suas novas habilidades para orientar familiares ou amigos.

Lai (2011), ressalta o papel do letramento informacional na redução da exclusão digital, entendida não apenas como a falta de acesso às tecnologias de informação e comunicação, mas a também a falta de conhecimentos e habilidades no manejo da informação. Com base nos resultados de seu estudo, Lai (2011), estabeleceu quatro diretrizes para o desenvolvimento eficaz do letramento informacional em bibliotecas públicas, em que a Tecnologia da Informação é um dos elementos de destaque, conforme ilustrado na Figura 5.

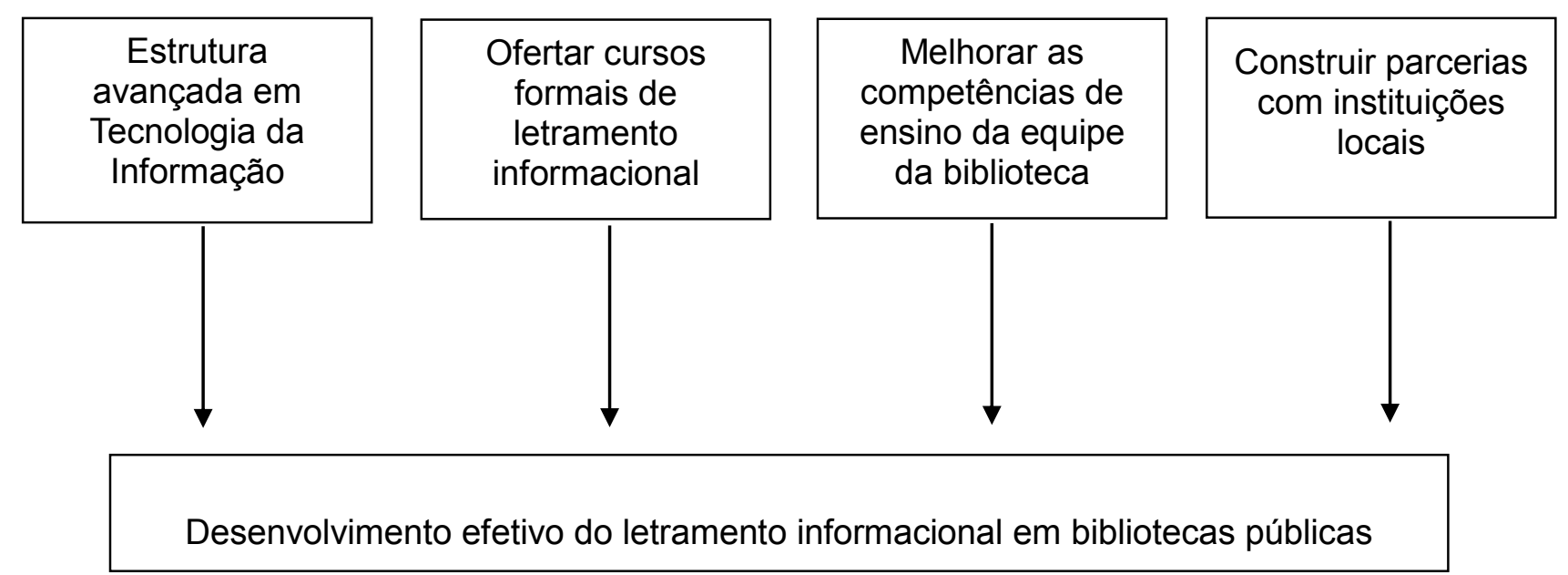

Figura 5: Diretrizes para o desenvolvimento eficaz de letramento informacional em bibliotecas públicas

Fonte: LAI, 2011 


\subsubsection{Elementos favoráveis ao desenvolvimento do Letramento Informacional nas Bibliotecas Públicas}

Apesar da pouca investigação sobre o assunto, é praticamente consenso na literatura que as bibliotecas públicas estão privilegiadamente posicionadas para atuarem como agentes-chaves no desenvolvimento do letramento informacional em suas comunidades. Sua presença constante na vida da comunidade, aliados aos seus objetivos e missões institucionais são os principais fatores que contribuem para isso.

Harding (2008) identificou na literatura sobre o assunto os pontos fortes das bibliotecas públicas no desenvolvimento do letramento informacional, quais sejam: 1 - Função tradicional e reconhecimento como local de aprendizado: bibliotecas públicas são reconhecidas desde sua origem como um local de aprendizado;

2 - Especialistas em letramento informacional: os princípios do letramento informacional estão relacionados aos valores tradicionais das bibliotecas públicas e bibliotecários são vistos como especialistas em letramento informacional;

3 - Ampla base de clientes: a diversidade de usuários da biblioteca pública, que deve atender às necessidades de toda a comunidade, desde crianças até idosos, grupos minoritários, de níveis educacionais e profissionais diversos amplia a oportunidade de desenvolvimento do letramento informacional;

4 - Primeira experiência de aprendizagem da criança: frequentemente a primeira experiência de aprendizado das crianças se dá na biblioteca, seja por experiências como a "hora do conto" ou o primeiro acesso à informação tecnológica. Assim, a biblioteca pode incentivar crianças a valorizar a informação, bem como apoiá-las no aprendizado para o acesso à informação, além de incutir o valor da biblioteca como fonte de informação e local de aprendizagem;

5 - Contato perene com os membros da comunidade: como o letramento informacional é um processo que se desenvolve ao longo da vida, as bibliotecas públicas estão estrategicamente posicionadas para ser uma presença constante na vida das pessoas de modo a fornecer suporte contínuo para os indivíduos no desenvolvimento do letramento informacional;

6 - Momentos ensináveis: a interação bibliotecário-usuário, como a que ocorre no serviço de referência é uma forma de desenvolver habilidades de letramento informacional;

7 - Parcerias: trabalho em conjunto com outras instituições como bibliotecas escolares 
ou universidades, desenvolvido por bibliotecas públicas;

8 - Pontos chave de acesso: bibliotecas públicas são fornecedoras de informação impressa e eletrônica e podem oferecer programas de treinamento e assistência especializada a cidadãos para adquirir habilidades de informação necessárias e desenvolver proficiência no uso dessas fontes.

\subsubsection{Dificuldades e desafios}

Problemas estruturais e escassez de recursos são velhos conhecidos das Bibliotecas Públicas em todo o mundo, que tem que lidar diariamente com estes obstáculos para fazer o seu trabalho e desempenhar o seu papel na sociedade. No desenvolvimento do letramento informacional não é diferente.

Julien e Hoffman (2008) identificaram os principais desafios enfrentados pelas bibliotecas públicas canadenses na promoção do letramento informacional. Os funcionários destas bibliotecas apontaram os seguintes fatores: desafios sociais mais amplos (como a penetração dos meios de comunicação e questões de inclusão digital), desafios institucionais nas bibliotecas (como marketing, funcionários, orçamento e planejamento de prioridades), problemas de infraestrutura nas bibliotecas e desafios pedagógicos, relacionados ao bibliotecário e seu papel educativo.

Ainda neste sentido, Gomez-Hernandez e Pasadas-Ureña (2007), relacionaram as principais dificuldades apresentadas na inclusão do Letramento Informacional na agenda das Bibliotecas Públicas, - algumas delas coincidentes com as relacionadas no estudo de Julien e Hoffman. Estas dificuldades estão relacionadas a vários aspectos, quais sejam:

\section{- Relacionadas a aspectos gerais:}

a) Falta de recursos financeiros, pessoal e equipamentos adequados;

b) Falta de consciência entre as autoridades de todos os níveis sobre a necessidade de coordenar esforços visando uma gestão mais eficaz dos recursos destinados às atividades de aprendizagem permanente.

c) A ausência do letramento informacional nos programas de muitos governos para a realização de qualificações profissionais e o desenvolvimento das competências básica.

d) Falta, até pouco tempo, de programas de letramento informacional planejados especificamente para as necessidades das bibliotecas públicas e poucos exemplos 
de boas práticas entre os próprios bibliotecários e entre as autoridades e agentes sociais.

- Relacionadas aos profissionais e suas concepções e competências:

a) Falta de conhecimento sobre as questões relacionadas ao letramento informacional, o que torna necessária a realização de campanhas de conscientização e informação, previamente à realização das atividades de letramento informacional, voltadas para autoridades, agentes sociais e público em geral;

b) Necessidade de maior colaboração entre os profissionais;

c) Maior empenho no desenvolvimento dos conceitos e terminologia relacionados ao letramento informacional em detrimento de experiências e aplicações práticas em benefício da população;

d) Deficiências na formação dos profissionais em competências e habilidades para promover a aprendizagem e o letramento informacional. Pouca reflexão sobre a necessidade de incluir essa pauta nos currículos das Universidades ou nas associações profissionais.

\section{- Relacionadas aos Usuários}

a) Dificuldades para realizar atuações específicas para novos grupos de usuários atraídos pela oferta de novos serviços, como a Internet.

b) O senso geral de que toda informação está facilmente acessível pela internet sem custos.

\section{-Relacionadas à Organização e avaliação}

a) Poucas alianças entre setores que permeiam a letramento informacional e o aprendizado ao longo da vida. Dificuldades de colaboração entre professores do ensino primário e secundário e bibliotecas públicas, ausência de colaboração entre bibliotecários que atuam nos diversos níveis educacionais com as bibliotecas públicas e institucionais.

b) Dificuldades para a integração dos conteúdos de letramento informacional nos planos de estudo dos diversos níveis da educação formal e ausência de marcos curriculares padronizados para adaptação e ajuste às necessidades locais, sobretudo em bibliotecas públicas e institucionais. Falta de consciência de que a oferta de formação e educação em letramento informacional requer níveis de padronização e homogeneidade de conteúdos, pois do contrário estaria em risco uma das características fundamentais do letramento informacional, sua possibilidade de transferência; 
c) Poucos instrumentos desenvolvidos para a avaliação e/ou verificação dos avanços pessoais nos programas de letramento informacional, principalmente em contextos de educação não formal, como as bibliotecas públicas;

d) Falta de formas de avaliação de programas de letramento informacional pelas agências encarregas da qualidade na educação ou no setor público.

Harding (2008) também apontou as principais limitações das bibliotecas públicas aos seus esforços no desenvolvimento do letramento informacional, conforme abaixo:

1 - Falta de estrutura: apesar da expectativa em relação à biblioteca pública, percebese uma falta de linhas de direcionamento de como proceder no desenho e implementação de programas de letramento informacional em bibliotecas públicas. Necessidade de um modelo.

2 - Recursos: as bibliotecas públicas enfrentam desafios devido às restrições orçamentárias, quadro de pessoal insuficiente, espaço, instalações e infraestrutura inadequados.

3 - Atitudes e crenças: atitudes e crenças de funcionários e clientes desempenham papel preponderante na efetividade dos programas de treinamento. Bibliotecários tem dificuldade em verem a si mesmos como educadores e usuários tem dificuldades em reconhecer a biblioteca pública como provedora de treinamento em letramento informacional. Além disso há a necessidade de maior apoio e reconhecimento por parte do governo e da indústria a respeito do papel educativo da biblioteca pública.

4 - Clientela: a diversidade de clientes da biblioteca pública é uma oportunidade e um desafio, dada à dificuldade de atender e alcançar todos os segmentos da comunidade. Por isso a importância da segmentação e oferta de programas para grupos específicos. 5 - A natureza da biblioteca pública: é provável que os esforços de letramento informacional aconteçam mais em função da demanda do que como iniciativa da biblioteca pública.

6 - Treinamento/habilidades: Habilidades pedagógicas não fazem parte da formação do bibliotecário, que deve se aperfeiçoar nesse sentido, além disso devem desenvolver suas próprias habilidades e competências informacionais para atuar como agentes de letramento informacional,

7 - Avaliação: Pouca base de como avaliar a efetividade dos programas de letramento informacional e o impacto dos serviços fornecidos dificultam elencar justificativas para a continuidade dos serviços. 
8 - Promoção: Falta de conhecimento sobre marketing para divulgação dos serviços e alcance dos não usuários.

9 - Fatores Culturais: impactam o trabalho das bibliotecas públicas em várias partes do mundo.

Portanto, as bibliotecas públicas têm muitos desafios a enfrentar e problemas estruturais, sociais e culturais com que lidar para tornar efetivo o desenvolvimento do letramento informacional. Conforme observa Ouwsu-Ansah (2003) apud GomezHernandez e Pasadas-Ureña (2007), se existem controversas não é por falta de uma boa definição (terminológica), mas pela ausência de linhas claras de atuação e de oportunidades para levá-las a cabo, ou seja, não há incertezas conceituais, mas sim dificuldades de aplicação em contextos muito diferentes.

\subsubsection{O Bibliotecário como agente do Letramento Informacional nas Bibliotecas Públicas}

A conscientização e o engajamento por parte dos bibliotecários são pontos centrais da questão do letramento informacional nas bibliotecas públicas, uma vez que este profissional deve ter a clareza do seu papel como educador, a fim que possa atuar na formação de competências e habilidades informacionais, considerando o contexto em que atua e as necessidades específicas da sua comunidade.

Elmborg (2006), discorre sobre as mudanças de demanda nos serviços bibliotecários das bibliotecas associadas à ARL (American Research Library), as quais no período entre 1991 e 2002 , tiveram uma queda de $26 \%$ no número de atendimentos do serviço de referência e um aumento de 55\% nas apresentações para grupo. Essas mudanças, impulsionadas pela demanda, implicam numa evolução do que fazem os bibliotecários, que passam de provedores de serviços a educadores ativos, o que representa um desafio para os profissionais no sentido de desenvolver novas filosofias de orientação aos usuários. Para o autor, uma forma de fazer frente a esse desafio é que a formação do bibliotecário o prepare mais diretamente para cobrir essas novas funções educativas.

Ainda sobre a formação dos bibliotecários, Suaiden (2002) ressalta que deve haver uma forte mudança a curto e médio prazo nos currículos e principalmente na atitude dos profissionais. Isso, porque a formação de profissionais conscientes e preparados para os desafios inerentes ao processo de mediação da informação e 
inclusão social é um fator determinante para que as bibliotecas públicas possam converter-se em um meio mais eficaz para a inclusão das populações marginalizadas do processo educativo e cultural. Assim, um dos grandes desafios para o profissional da informação e um importante passo para a formação da "cultura informacional" é educar a si próprios e educar aos outros para a sociedade da informação (TARAPANOFF; SUAIDEN; OLIVEIRA, 2002).

Deste modo, Lloyd (2005) afirma que:

"Se nós, bibliotecários, queremos ensinar competências informacionais e dar base à noção de qualidades transformadoras do letramento informacional e sua capacidade de engajar, permitir, enriquecer e incorporar indivíduos em suas práticas, profissões e comunidades, então precisamos ir além do nosso entendimento somente de discurso do que é letramento informacional, precisamos entender como as práticas de letramento informacional se manifestam nos diversos contextos." (Tradução livre da autora)

Nessa perspectiva, e com o intuito de verificar como os bibliotecários vivenciam o papel educativo nas bibliotecas canadenses, Julien e Genuis (2011) realizaram uma pesquisa nacional com 788 funcionários de bibliotecas, onde exploraram a identidade profissional relacionada ao ensino, bem como as experiências e habilidades pedagógicas desses profissionais. $25 \%$ dos questionários respondidos foram de profissionais de bibliotecas públicas. Sobre os desafios enfrentadas pelos profissionais no desempenho desse papel, Julien e Genuis (2011) identificaram três áreas primárias de dificuldade, quais sejam:

1- Desafios externos, contextuais, como ambiente administrativo e tecnologia de ensino;

2- Desafios da interação com usuários e professores (neste caso, de profissionais de bibliotecas escolares e universitárias); e

3- Desafios intrapessoais, relacionados às características pessoais individuais e/ou à falta de preparo para a função educativa.

A maioria dos profissionais, no estudo de Julien e Genuis (2011), identificou o papel educativo como parte integrante da identidade profissional, cerca de 1/3 encaram este papel como um dever ou expectativa e uma pequena porção o identificam como uma imposição. Outro dado interessante, é que a maioria dos profissionais entrevistados entendem que o papel do bibliotecário está em transição, e que a função educativa está em expansão. O estudo enfatiza o papel crítico da autoconcepção dos profissionais em relação às suas funções e a importância do apoio 
dos gestores à capacitação dos profissionais e da valorização do trabalho educativo como formas de influenciar positivamente o modo como os profissionais encaram essa função.

Cientes disso, DEMASSON, PARTRIDGE e BRUCE (2010) utilizaram a fenomenografia para verificar como bibliotecários de bibliotecas públicas de uma região da Austrália concebem, vivenciam e experimentam o letramento informacional. Apesar da pequena amostra, limitação geográfica e do caráter preliminar do estudo, a investigação é uma importante contribuição e serve de modelo para estudos futuros. O estudo identificou quatro categorias distintas e uma subcategoria, cada uma descrevendo uma forma única com que pelo menos um dos participantes experimentam o fenômeno em questão. As categorias identificadas foram:

1. Social: os respondentes apontaram o letramento informacional como parte integrante do dia-a-dia da vida das pessoas. Nesta categoria, o foco principal é o desenvolvimento de habilidades que permitirão ao indivíduo viver com sucesso em um mundo dominado pela informação;

2. Intelectual/Avaliativo: o letramento informacional se constitui como um processo intelectual, onde as pessoas não apenas têm a consciência de todas as possíveis maneiras de acessar as informações, como são capazes de avaliar sua validade, confiabilidade e valor. Nesta categoria, o foco principal é fazer uma escolha informada e fundamentada quanto à fonte de informação, ferramenta ou recurso mais confiável, válido e apropriado dentre os muitos que estão disponíveis.

3. Técnica/Tecnológica/Prática: constitui o letramento informacional como a capacidade de usar as ferramentas de tecnologia da informação para acessar informações. O foco principal desta categoria está nas habilidades necessárias para usar as ferramentas tecnológicas para acessar e usar a informação.

3A. Resultado e não processo: constitui o letramento informacional como forma para alcançar um objetivo predeterminado. O foco principal é a obtenção de um resultado desejado por meio do uso da informação. É visto como um resultado e não um processo.

4. Falta de significado: o letramento informacional é constituído como um processo, conceito ou teoria que não tem um significado específico. Nesta categoria o foco primário é a falta de identificação e envolvimento com o conceito de letramento informacional.

Chamou a atenção dos pesquisadores DEMASSON, PARTRIDGE e BRUCE 
(2010), o fato que o letramento informacional parece constituir-se como uma atividade solitária e egocêntrica, o que vai de desencontro com a atividade altamente socializada dos bibliotecários de bibliotecas públicas. Esta constatação sugere que uma mudança nas opiniões e/ou, muito provavelmente, nas atitudes será necessária para que o letramento informacional se torne, verdadeiramente, uma prática efetiva das bibliotecas públicas.

\subsubsection{Cooperação e Parcerias}

Outro ponto com bastante destaque na literatura é a importância da cooperação entre bibliotecas públicas e outras instituições, para o desenvolvimento do letramento informacional. O trabalho colaborativo com bibliotecas escolares, universidades, lideranças comunitárias, dentre outros enriquece e diversifica a experiência da biblioteca pública com o letramento informacional (ELMBORG, 2006; HARDING, 2008; LAI, 2011; HALL, 2010).

Harding (2008), destaca o trabalho desenvolvido com parcerias como um importante ponto de atuação da biblioteca pública na promoção do letramento informacional, as quais se dão de formas variadas. A forma de parceria mais defendida é a estabelecida entre bibliotecas públicas e escolas ou instituições acadêmicas e ainda, as parcerias entre bibliotecas públicas e provedores de informação comunitária, entidades governamentais e empresas privadas e entre bibliotecas públicas e indivíduos da comunidade, como voluntários.

Os manifestos da UNESCO destacam a importância da cooperação educativa entre bibliotecas públicas e escolares. Nas Diretrizes IFLA/UNESCO para o desenvolvimento dos serviços da biblioteca pública (2012), essa relação é definida como "uma das relações institucionais mais importantes". Entre as formas de cooperação elencadas destaca-se a "cooperação no desenvolvimento de ferramentas de aprendizagem" e a "programação de esclarecimentos sobre a internet para crianças". As Diretrizes IFLA/UNESCO para a biblioteca escolar, também reforçam o trabalho conjunto entre bibliotecas escolares e públicas.

A Declaração de Maceió sobre competência em Informação (2012), também aborda esta questão. O documento ressalta a necessidade de bibliotecas, instituições e profissionais interessados no fomento e promoção da Competência em Informação estabelecer relações para a coordenação e desenvolvimento de ações conjuntas. 
Para Lai (2011), as bibliotecas públicas podem expandir seus serviços mantendo relações com outras instituições locais, como centros comunitários, centros de idosos, escolas e universidades, de que se do a enriquecer as experiências de aprendizagem da comunidade ao longo da vida. A autora cita o exemplo do trabalho colaborativo realizado entre bibliotecas públicas e serviços de imigrantes, oferecendo cursos aos imigrantes, o que contribui para a sua integração com os canadenses, além de ajudar a encontrar emprego.

O estabelecimento de parcerias e a realização de trabalho cooperativo e colaborativo reflete a capacidade da biblioteca pública de se engajar e dialogar com outros setores da comunidade visando o cumprimento de seu papel social e educativo. Como ressalta Crippa (2015), "são necessárias escolhas firmes do conjunto de cooperação que se traduz na construção paciente de parcerias, redes e compartilhamentos vários, na convicção de que para encontrar algo de novo é necessário abandonar algo de velho". Ou seja, é vital uma postura ativa, aberta e acolhedora rumo ao novo que se desdobra do fruto das relações e do trabalho conjunto com outras instituições e com a própria comunidade.

\subsection{BREVES CONCLUSÕES DA REVISÃO DE LITERATURA}

A revisão de literatura centrou-se nas temáticas: biblioteca pública, letramento informacional, sociedade da informação, modelos e abordagens de letramento informacional e bibliotecas públicas e letramento informacional e seus desdobramentos, e permitiu conceituar e contextualizar o fenômeno estudado.

Observou-se que a biblioteca pública no Brasil, que em seu surgimento baseou-se em modelos de outros países, sem considerar os aspectos culturais e sociais locais e que teve uma trajetória baseada em políticas pouco eficientes, chega à atualidade com a missão de se reinventar e se readequar às novas necessidades sociais ao mesmo tempo em que tem que lidar com antigos desafios. Emerge a importância da dimensão social da biblioteca pública, baseada no convívio social e comunitário, na construção coletiva do conhecimento e na valorização das dimensões discutir e criar a partir do espaço da biblioteca.

O letramento informacional, por sua vez, tem se mostrado um conceito dinâmico, que surgiu com um determinado propósito e vem se ampliando conforme 
avançam as pesquisas e a sociedade. O conceito inicial relacionado a habilidades cognitivas para o acesso e uso efetivo da informação amplia-se a partir do entendimento do letramento informacional como um fenômeno social e culturalmente situado, essencial para a plena participação na Sociedade da Informação, para o exercício da cidadania e participação na democracia, para o engajamento no processo de aprendizagem, o aprendizado autônomo ao longo da vida e para o empoderamento social individual e coletivo.

A partir da proliferação das pesquisas sobre a temática emergem modelos e abordagens para o estudo e entendimento do fenômeno. Modelos como os de Kuhthau, (1991), dentre outros, fornecem um embasamento para a compreensão e análise do comportamento informacional dos usuários, que é a base para qualquer sistema de informação. O prévio conhecimento da comunidade, suas necessidades e o seu comportamento informacional são essenciais para a criação e o desenvolvimento de programas de letramento informacional.

Abordagens alternativas como a relacional utilizada por Bruce (1997), a abordagem crítica defendida por Elmborg (2006) e Hall (2010) e a abordagem social proposta por Lloyd (2005), mostram que há várias formas de conceituar e vivenciar o fenômeno e que não há uma única verdade quando o assunto é letramento informacional e sim múltiplos contextos. Esta compreensão é bastante útil para lidar com o fenômeno, principalmente no âmbito da biblioteca pública, que transita por tantas vertentes da comunidade e está situada em realidades tão múltiplas. Elementos presentes nestas abordagens alternativas como o pensamento crítico e a interação social e cultural são fundamentais para pensar o letramento informacional no contexto das bibliotecas públicas, pois mais que transformar a biblioteca em sala de aula é preciso engajar-se com a comunidade e promover uma ação transformadora.

As pesquisas e estudos que abordam letramento informacional e bibliotecas públicas, especificamente, mostraram-se bastante reduzidos. A maior fatia dos trabalhos utilizados para a revisão deste tópico foi de língua inglesa, oriundos, principalmente, dos Estados Unidos, Canadá, Austrália e Inglaterra, além de alguns estudos em língua espanhola. Nos estudos realizados no Brasil foram encontradas apenas algumas menções sobre as bibliotecas públicas, mas nenhum trabalho específico sobre a questão.

Observou-se que a função educativa não é um papel novo para as bibliotecas públicas, ao contrário, sempre esteve presente em sua linha de atuação. O que há é 
uma reconfiguração de antigos papeis para atender a novas demandas e necessidades geradas pela sociedade, além do posicionamento privilegiado e estratégico da biblioteca pública na comunidade, configurando-a como ambiente ideal para o aprendizado permanente.

Além dos aspectos que privilegiam a biblioteca pública, a literatura apontou para oportunidades de atuação, como a relacionada à inclusão digital e ao trabalho colaborativo com outras instituições. A alta penetração das tecnologias da informação e o seu uso massivo para o acesso à informação a tornam um ponto importante a ser considerado quando se trata de letramento informacional. E as bibliotecas públicas, neste sentido, mais que prover o acesso a essas tecnologias deve fornecer meios para capacitar a comunidade para o uso crítico e eficaz, contribuindo para a inclusão digital e democratização do acesso à informação.

No que tange à cooperação com outras instituições, a literatura demonstrou ser um ponto crucial para a atuação das bibliotecas públicas na promoção do letramento informacional. A cooperação mais citada e recomendada é com as bibliotecas escolares e instituições educacionais, dentre outras instituições e até membros da comunidade. Além disso, foram identificadas nos diversos estudos e investigações, barreiras e dificuldades enfrentadas pela biblioteca pública nesta empreitada do letramento informacional, principalmente a falta de recursos e infraestrutura necessária, questões culturais e sociais, além das atitudes e crenças: de um lado estão os bibliotecários que muitas vezes não se veem como educadores e de outro os usuários, que tem dificuldade em reconhecer legitimidade na biblioteca pública enquanto espaço educativo.

Quanto aos bibliotecários, apesar de serem apontados como "especialistas em letramento informacional", muitos ainda não estão totalmente familiarizados com a questão, o que leva a uma séria reflexão, tendo em vista a influência exercida pela sua autoimagem e a auto concepção em sua atuação, o que denota, ainda, a relevância deste estudo. 


\section{METODOLOGIA}

Este capítulo aborda os aspectos metodológicos do estudo. Abrange o referencial teórico adotado, a caracterização da pesquisa, aspectos ontológicos e epistemológicos do método empregado, além de instrumentos e procedimentos utilizados para coleta e análise dos dados.

\subsection{REFERENCIAL TEÓRICO}

A partir da revisão de literatura foram selecionados os conceitos que compõe o referencial teórico do presente estudo e que, portanto, sustentam e direcionam a pesquisa.

O conceito de biblioteca pública emerge dos apontamentos de Crippa (2015), Milanesi (2002; 2013), Suaiden (2000; 2002; 2013; 2014), Herrera-Viedma e LópezGijón (2013) e Lozano Días (2006). Portanto, para fins desta pesquisa a biblioteca pública será entendida como "um espaço social de convivência, aprendizagem e reflexão, onde as pessoas podem se informar, mas também aprender, discutir, criar e compartilhar suas experiências e conhecimentos e crescer como cidadãos de uma comunidade e plenos participantes da sociedade da informação".

O conceito de letramento informacional adotado neste estudo deriva dos estudos e definições de Bruce (1997), Elmborg (2006), Hall (2009) e Lloyd (2005) e considera o contexto da biblioteca pública. Portanto, o letramento informacional no contexto da biblioteca pública será entendido como: "Um conjunto complexo de habilidades, experiências e concepções relacionadas ao uso da informação, que pode ser vivenciado e experimentado de diferentes formas em diversos contextos, como a vida comunitária. Configura-se, portanto, em atividade colaborativa e social, dependente de relacionamentos pessoais e comunitários, ou seja, um fenômeno 'culturalmente situado', baseado no modo como as comunidades constroem significado e ideia de pertencimento. Centra-se no desenvolvimento da consciência crítica dos indivíduos a partir da qual é possível formar agentes ativos, capazes de formular e responder questões que os afetam diretamente ou ao mundo à sua volta $e$ em última instância a capacidade de levantar problemas e agir sobre o mundo, a fim de mudá-lo".

O desenvolvimento do letramento informacional é considerado determinante 
para a participação da comunidade na Sociedade da Informação, cujo conceito adotado na pesquisa é a definição de Castells (2003), "nova ordem social em que a geração, o processamento e a transmissão da informação tornam-se as fontes fundamentais de produtividade e poder".

Ao considerar o letramento informacional um conjunto complexo de experiências e concepções, abre-se espaço para a utilização da fenomenografia como método para identificar as diferentes concepções de letramento informacional dos bibliotecários. Fenomenografia é o estudo empírico das maneiras diversas, qualitativas e limitadas em que um determinado fenômeno é experimentado, conceituado, compreendido, assimilado, percebido (MARTON, 1994). As concepções por sua vez, são as maneiras em que as pessoas experimentam, percebem, apreendem, compreendem e conceituam os diversos fenômenos e aspectos do mundo ao seu redor (MARTON, 1994; 2007).

Portanto, a fenomenografia será utilizada para identificar as concepções dos bibliotecários sobre o letramento informacional. Concepções estas que influenciam o desenvolvimento do letramento informacional no âmbito das bibliotecas públicas, cujo elemento essencial é o desenvolvimento do pensamento crítico de forma colaborativa e social, configurando a biblioteca como um espaço social de convivência, aprendizagem e reflexão, que promove a participação na sociedade da informação. Assim, o desenho da pesquisa é representado pela Figura 6:
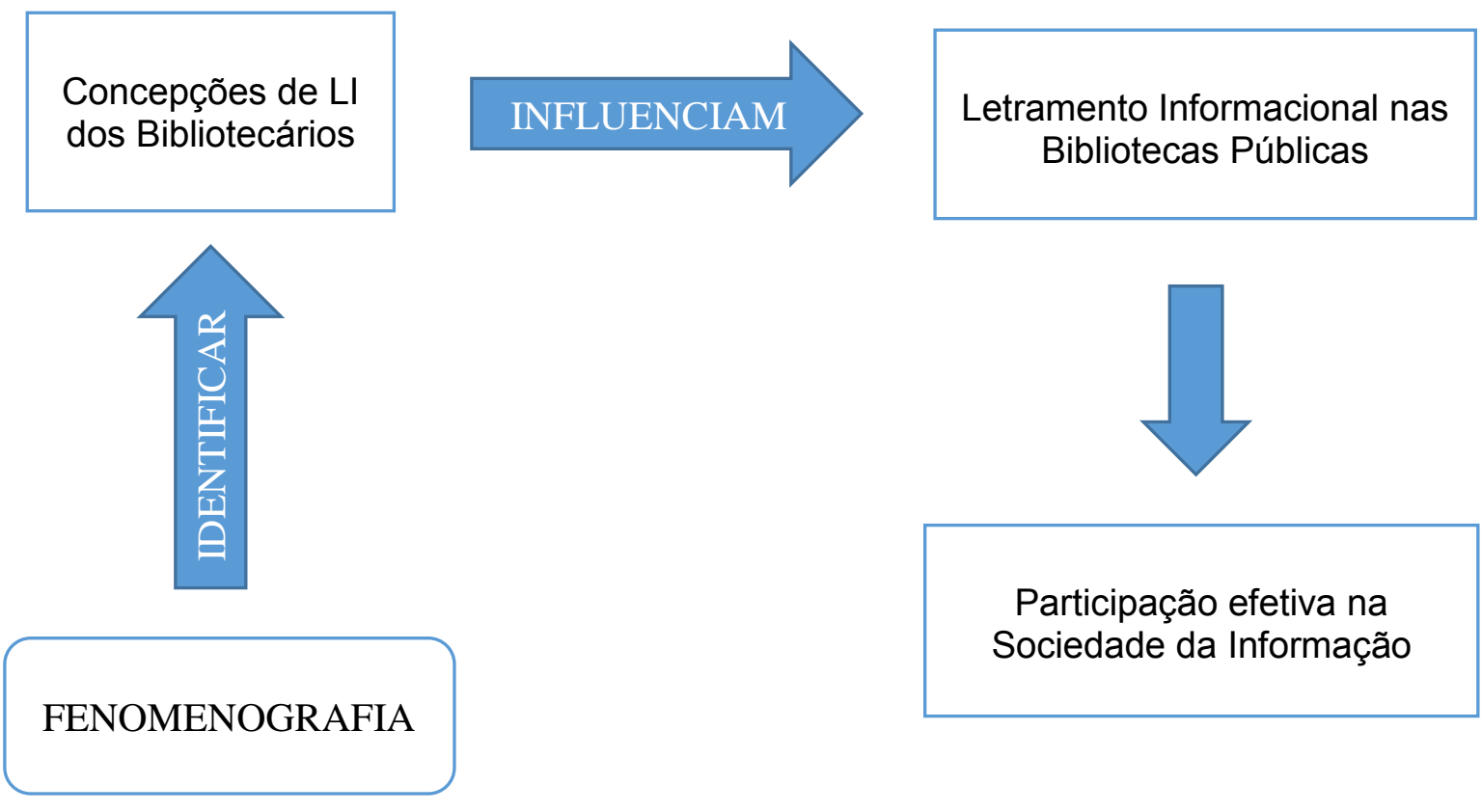

Figura 6: Referencial Teórico/Desenho da Pesquisa Fonte: Elaboração própria

Participação efetiva na Sociedade da Informação 


\subsection{CARACTERIZAÇÃO DA PESQUISA}

Assim como o letramento informacional tem muitas faces, também há muitas maneiras de entender, experimentar e conceituar o fenômeno. Isso ilustra a sua complexidade e evidencia que nós estamos somente começando a explorar e entender seu escopo e seu potencial. Compreender o letramento informacional como um fenômeno qualitativo usando métodos baseados na fenomenografia é uma forma de fazer isso (LLOYD, 2005).

Deste modo, a metodologia do presente estudo, de abordagem qualitativa e caráter exploratório - uma vez que há pouco conhecimento sistematizado sobre a questão - utilizará o método fenomenográfico para identificar e descrever as diferentes concepções dos bibliotecários que atuam em bibliotecas públicas estaduais brasileiras sobre como conceituam, compreendem e vivenciam o letramento informacional.

Na pesquisa qualitativa, a característica central é a prioridade à perspectiva daqueles que estão sendo estudados, mais do que sobre as preocupações prévias do pesquisador ou sobre um modelo teórico específico (BRYMAN, 2000 apud AMARO; BRUNSTEIN, 2013). Conforme apontam Denzin e Lincoln (2005) apud Flick (2009, p. 16), a pesquisa qualitativa é definida como:

Uma atividade situada, que posiciona o observador no mundo.
Consiste em um conjunto de práticas interpretativas que tornam o
mundo visível. [...] A pesquisa qualitativa envolve uma postura
interpretativa e naturalista diante do mundo. Isso significa que os
pesquisadores desse campo estudam as coisas em seus contextos
naturais, tentando entender ou interpretar os fenômenos em termos
dos sentidos que as pessoas lhe atribuem.

\subsubsection{Fenomenografia: aspectos ontológicos e epistemológicos}

A fenomenografia surgiu no final dos anos 1970, em Gotemburgo, na Suécia, tendo como principal expoente o pesquisador Ference Marton. O objetivo dos primeiros estudos fenomenográficos era compreender porque alguns alunos aprendiam melhor que outros. Os resultados desses estudos mostraram que as concepções de aprender dos alunos exerciam influência sobre a aprendizagem. O termo tem origem etimológica grega e deriva das palavras "phainemonon" (o aparente, 
que pode ser percebido ou vivenciado) e "gráphein" (grafia, descrição).

Na fenomenografia o principal objetivo, conforme Marton (1981, p.180), é "encontrar e sistematizar formas de pensamento, em termos dos quais as pessoas interpretam aspectos da realidade que são socialmente significativos e presumidamente compartilhados pelos membros de um tipo de sociedade". O propósito do método é o mapeamento e a descrição das diferentes formas ou concepções com que os indivíduos experimentam e/ou vivenciam determinados fenômenos (MARTON, 1997).

Salienta-se que fenomenografia não é o mesmo que fenomenologia. Resguardadas as semelhanças: as duas tem a experiência humana como objeto, cabe ressaltar as diferenças: enquanto na fenomenologia, a essência é o fenômeno em si, para a fenomenografia o foco são as experiências e percepções geradas pelo fenômeno, ou seja, as relações entre os sujeitos e os fenômenos ou entre as pessoas e o mundo (MARTON, 1994).

Neste sentido, a fenomenografia adota uma perspectiva ontológica não dualista. Ou seja, não há um mundo "lá fora", independente das percepções do indivíduo, mas sim uma relação indissociável entre a pessoa e o mundo, por meio da experiência vivida. Os estudos fenomenográficos não consideram o fenômeno e o sujeito como entidades separadas. Em vez disso, há sempre uma busca em estabelecer relação entre o sujeito da pesquisa (a pessoa que experimenta, vivencia, conceitua o fenômeno) e os aspectos do mundo (o fenômeno).

Assim, a relação que se estabelece entre uma pessoa e um determinado fenômeno no mundo é intitulado como "abordagem relacional "(MARTON, 1994; LIMBERG, 2012; ARKELIND, 2005). O aspecto relacional e a visão não dualista são fundamentais para a compreensão da ontologia e epistemologia da fenomenografia (ARKELIND, 2005; GREEN, 2005 APUD CHERMAN, 2013). A figura 7 ilustra o objeto de pesquisa da fenomenografia, ao passo que ressalta seu aspecto relacional, dialógico e não dualista. 


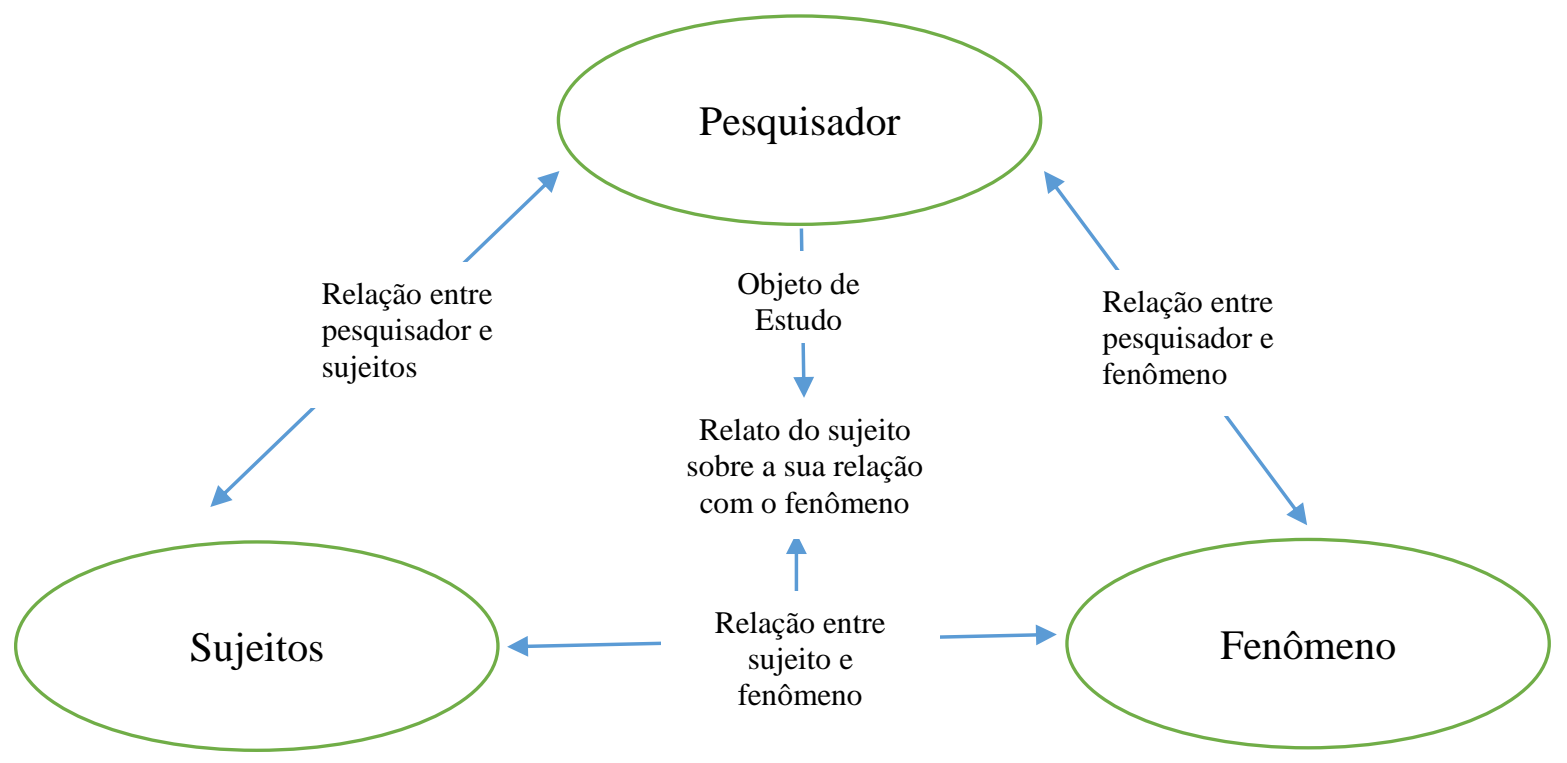

Figura 7: Aspecto relacional da Fenomenografia

Fonte: LOPES, 2012 ADAPTADO DE BOWDEN, 2005

Para alcançar essa relação entre os sujeitos e o fenômeno, o pesquisador adota uma perspectiva de segunda ordem (MARTON, 1981). A perspectiva de segunda ordem consiste em orientar a pesquisa para alcançar declarações dos indivíduos sobre suas ideias, com base na sua experiência da realidade. Ou seja, a fenomenografia não investiga o fenômeno como ele é - o que implicaria uma perspectiva de primeira ordem - mas o aborda do ponto de vista dos sujeitos que o experimentam.

O resultado que se busca com uma pesquisa fenomenográfica é a compreensão de como o indivíduo apreende (percepção), faz sentido (significação e pensamento) e atua (ação) um aspecto específico de seu mundo. Ao trinômio percepção-pensamento-ação atribui-se o termo concepção (SANDBERG, 2000; PELLEGRINELLI et. AI., 2003 APUD CHERMAN, 2013). Para a fenomenografia, qualquer fenômeno, conceito ou situação pode ser experimentado em um número limitado de formas. Esses diferentes modos são denominados concepções, um conceito central na fenomenografia. As concepções são, portanto, as maneiras em que as pessoas experimentam, percebem, apreendem, compreendem e conceituam os diversos fenômenos e aspectos do mundo ao seu redor. Significa discernir aspectos de um fenômeno e estar paralela e focalmente consciente deles (MARTON, 1994; MARTON, 2007).

O pressuposto básico do método é que os fenômenos são vivenciados de várias maneiras e que é possível capturar e descrever os padrões de variação destas 
experiências em um número limitado de categorias que, juntos, dão forma ao fenômeno (MARTON, 1981; LIMBERG, 2012). Lopes (2012), afirma que a diferença entre as categorias decorre da variação ou simultaneidade dos aspectos percebidos sobre o fenômeno. Essas diferenças entre as categorias são chamadas de dimensões de variação que indicam como as várias categorias estão relacionadas entre si. Ou seja, enquanto as categorias de descrição representam os significados qualitativamente diferentes atribuídos ao fenômeno vivenciado, ou aspecto relacional da experiência com o fenômeno, as dimensões de variação representam a estrutura dessa variação de significado, ou aspecto estrutural da experiência com o fenômeno (MARTON e BOOTH, 1997).

O conjunto de categorias descritivas das concepções, lógica e hierarquicamente organizadas, que refletem os modos de experimentar um fenômeno é chamado espaço de resultado (outcome space), produto da pesquisa fenomenográfica. No espaço de resultado as categorias descritivas são organizadas por graus crescentes de compreensão, onde as mais avançadas representam uma compreensão mais completa ou complexa do fenômeno, enquanto aquelas menos avançadas representam uma compreensão menos complexa ou completa. (MARTON; TSUI, 2004 apud GONZÁLEZ-UGALDE, 2014).

Cabe ressaltar que o espaço de resultado representa a variação nas formas coletivas de experimentar um fenômeno e não busca, portanto, a descrição da experiência individual e sim desvendar a anatomia da consciência coletiva (MARTON, 2007 apud GONZÁLEZ-UGALDE, 2014). Marton e Booth (1997) apud González Ugalde (2014), descrevem três critérios para desenvolver um espaço de resultado:

1- Cada categoria deve refletir algo distinto sobre o fenômeno;

2- As categorias devem ser apresentadas em uma relação lógica e hierárquica entre si;

3- O espaço de resultado deve ser parcimonioso, ou seja, apresentar um conjunto com o menor número possível de categorias descritivas para captar a variação das concepções.

\subsubsection{Fenomenografia e letramento informacional}

Desde seu surgimento na década de 1970, a fenomenografia tem sido bastante empregada em seu berço de origem, a área da educação, ao passo que vem 
sendo amplamente utilizada em outras áreas do conhecimento, em especial nas ciências sociais. O método é a base para uma série de estudos proeminentes sobre letramento informacional realizados em países como a Suécia, a Austrália e os Estados Unidos.

A fenomenografia foi utilizada por Bruce (1997) para extrair, a partir da experiência de professores de duas universidades da Austrália, diferentes formas de vivenciar o letramento informacional, dando origem ao modelo "as sete faces do letramento informacional". Também foi empregada por DEMASSON, PARTRIDGE e BRUCE, (2010) para identificar as concepções de letramento informacional de bibliotecários públicos na Austrália. DEMASSON, PARTRIDGE e BRUCE, (2010) ressaltam que sua pesquisa deve ser vista como um estudo preliminar, tendo em conta algumas limitações, tais como o número da amostra e a restrição geográfica. No entanto apesar de não apresentar conclusões, resultados e categorias representativas definitivas, serve como base para a realização de outros estudos semelhantes, como é o caso deste trabalho.

Além de ter este estudo (DEMASSON, PARTRIDGE e BRUCE, 2010) como base, levou-se em conta no desenho desta pesquisa as considerações para os estudos futuros apontados pelos autores, que foram de grande valia para as adequações necessárias a fim de evitar resultados que apresentem as mesmas limitações. Foram considerados, principalmente, os aspectos relacionados ao número da amostra e abrangência geográfica e os relacionados às questões da entrevista.

\subsection{SELEÇÃO DA AMOSTRA, PRÉ-TESTE E COLETA DE DADOS}

Quanto à seleção dos sujeitos, os indivíduos incluídos na amostra devem ter relação com o fenômeno estudado. Além disso, como o objetivo é encontrar variação nas experiências, é necessário assegurar que esta variação possa emergir. (MARTON; BOOTH, 1997; BOWDEN, 2000 APUD GONZÁLEZ-UGALDE, 2014). Em busca de se maximizar a variação dos modos de ver o fenômeno, a escolha dos participantes deve ter esse objetivo da variedade. Por isso, recomenda-se o uso de amostra intencional, ou seja, a seleção dos sujeitos deve ser feita com esta finalidade (GREEN, 2005).

Com relação ao tamanho da amostra Trigwell (2000) e Marton (1981; 1994), recomendam amostras de quinze a vinte casos, como número suficiente para descobrir todas as diferentes formas de compreensão de determinado fenômeno. 
Sendo quinze o número mínimo para assegurar a oportunidade de descobrir a variação e vinte o número razoável tendo em vista o grande volume de dados produzidos e a capacidade do pesquisador para analisá-los. No entanto, foram observadas amostras com menos de 15 sujeitos em diversas pesquisas empíricas onde o método fenomenográfico foi empregado.

Considerando as diretrizes expostas acima, a composição da amostra intencional objetivou a seleção de 15 sujeitos para participar da pesquisa bibliotecários que trabalham em bibliotecas públicas estaduais. A fim de assegurar que os participantes tenham relação ou experiência com o fenômeno, os bibliotecários selecionados deveriam atuar no serviço de referência ou em algum serviço em que tivessem contato direto com o usuário. Isso, por se entender que o bibliotecário de referência ou aquele que desenvolve algum serviço em contato direto com o usuário - como por exemplo, educação de usuários, incentivo à leitura, cursos - está mais propenso a desenvolver ações, atividades, projetos, etc. relacionados à aprendizagem e ao letramento informacional, do que um bibliotecário que trabalhe essencialmente com processamento técnico, por exemplo.

Buscou-se a variação nos modos de ver e vivenciar o fenômeno, com base na abrangência geográfica. Tendo em vista os contextos, culturas e realidades distintas - e, portanto, múltiplas experiências - dos profissionais das diversas regiões e estados do país. Deste modo, foram selecionados 15 bibliotecários, atuantes em bibliotecas públicas estaduais, sendo 3 bibliotecários de cada região do país, para compor a amostra.

Foi estabelecido contato direto por telefone e/ou e-mail com as bibliotecas públicas, em ordem aleatória dos estados, até alcançar a quantidade de 3 bibliotecários por região, além dos 2 que participaram das entrevistas piloto, conforme composição apresentada no Quadro 6. Cabe ressaltar que, em algumas regiões para chegar a esta quantidade foi necessário entrar em contato com as bibliotecas públicas de todos os estados, esbarrando em problemas como bibliotecas fechadas ou sem nenhum bibliotecário, tentativas frustradas de contato por telefone e e-mail e em alguns casos, até mesmo recusa em participar da pesquisa. 


\begin{tabular}{|l|l|}
\hline Região & Entrevistados \\
\hline \multirow{4}{*}{ Nordeste } & E1 \\
\cline { 2 - 2 } & E2 \\
\cline { 2 - 2 } & E3 \\
\cline { 2 - 2 } & Entrevista Piloto 1 \\
\hline \multirow{4}{*}{ Centro-Oeste } & E4 \\
\cline { 2 - 2 } & E5 \\
\cline { 2 - 2 } & E6 \\
\hline & Entrevista Piloto 2 \\
\hline \multirow{4}{*}{ Norte } & E7 \\
\hline \multirow{4}{*}{ Sul } & E8 \\
\hline & E9 \\
\hline \multirow{3}{*}{ Sudeste } & E10 \\
\hline & E11 \\
\cline { 2 - 2 } & E12 \\
\hline & E13 \\
\hline & E14 \\
\cline { 2 - 2 } & E15 \\
\hline
\end{tabular}

Quadro 3: Variação Demográfica da Amostra Fonte: Elaboração própria

A coleta de dados foi realizada por meio de entrevistas individuais em profundidade - em que os bibliotecários foram encorajados a falar sobre suas experiências e impressões - com o objetivo de revelar suas vivências e percepções em relação ao letramento informacional no contexto da biblioteca pública. Nas entrevistas em profundidade, ao invés de se responder a perguntas por meio de diversas alternativas previamente formuladas, visa obter do entrevistado o que ele considera os aspectos mais relevantes de um determinado problema. Por meio de uma conversação guiada, se obtêm informações detalhadas que possam ser utilizadas em uma análise qualitativa (RICHARDSON, 1999).

A maioria das pesquisas empíricas que adotam abordagem fenomenográfica são conduzidas por entrevistas. As entrevistas são, geralmente, semiestruturadas ou não estruturadas e concentram um número limitado de perguntas que visam captar as diferentes maneiras em que entrevistados experimentam um determinado fenômeno, por exemplo o letramento informacional (LIMBERG, 2012).

Para a realização das entrevistas foram consideradas as diretrizes apontadas por Marton $(1981 ; 1994)$ que recomenda entrevistas flexíveis, com perguntas abertas. Recomenda-se ainda que, além de ter uma lista prévia de perguntas, o pesquisador 
mantenha uma atitude aberta para os diferentes rumos que cada entrevista pode tomar. Para tanto, além de perguntas diretamente relacionadas à sua experiência com o fenômeno, como por exemplo "o que você entende por $x$ ? ", deve-se fazer perguntas de seguimento como "poderia me explicar mais? " ou "o que você quer dizer com isso?" Portanto, durante a pesquisa foram realizadas entrevistas em profundidade, semiestruturadas, compostas por um roteiro com perguntas principais, que foram complementadas por outras questões de acordo com as circunstâncias e o andamento da entrevista.

Aprimorar a técnica do entrevistador e testar o roteiro são passos importantes em qualquer pesquisa qualitativa e tornam-se ainda mais fundamentais na fenomenografia (AMARO; BRUNSTEIN, 2013). Seguindo este propósito foram realizadas duas entrevistas piloto como pré-teste a fim de testar e ajustar o roteiro da entrevista, bem como aprimorar a técnica da entrevistadora.

As entrevistas realizadas no pré-teste seguiram um roteiro de cinco perguntas abertas, conforme abaixo, intercaladas por perguntas intermediárias conforme 0 andamento da entrevista, a fim de aprofundar as concepções e os relatos de experiências dos entrevistados. O roteiro foi elaborado com base no instrumento utilizado por Demasson, Partridge e Bruce, (2010):

1. Descreva, com base na sua experiência, qual é a missão e o papel do bibliotecário que atua na biblioteca pública.

2. Descreva a sua experiência em ser um usuário eficaz da informação.

3. O que você acha que significa para os usuários da biblioteca em que você trabalha "ser um usuário eficaz da informação"?

4. O que você faz ou que serviços presta para ajudar os seus usuários a se tornarem usuários eficazes da informação?

5. Na sua opinião qual o papel do letramento informacional no trabalho de um bibliotecário que atua em biblioteca pública?

A primeira questão, sobre o papel do bibliotecário de biblioteca pública não fez parte do instrumento de coleta de dados de Demasson, Partridge e Bruce, (2010). A pergunta foi incluída uma vez que os autores sugerem o acréscimo dessa questão em trabalhos futuros, a fim de verificar se a forma como os bibliotecários veem seu papel e o papel da biblioteca pública se relaciona de alguma forma com o letramento informacional.

As entrevistas piloto foram realizadas por telefone com uma bibliotecária da 
região nordeste e outra da região centro-oeste. A partir da realização do pré-teste observou-se uma certa dificuldade dos entrevistados em entender e responder às questões 2 e 3, o que apontou para a necessidade de reformulação dessas perguntas. A questão 2 não alcançou o seu objetivo que seria direcionar para a experiência pessoal do entrevistado com o letramento informacional, assim como a questão 3 também não foi capaz de exprimir ao entrevistado o seu propósito de direcionar para a percepção do bibliotecário sobre a experiência do usuário. Ainda houve uma certa confusão com o termo "usuário eficaz da informação", substituído, durante as entrevistas do pré-teste, por "usuário competente em informação" a fim de testar se este seria melhor compreendido, porém continuou igualmente confuso para os entrevistados. O mesmo ocorreu com o termo letramento informacional, substituído por competência informacional diante da incompreensão do primeiro, porém sem sucesso. Foi constatada ainda, a mesma dificuldade encontrada por Demasson, Partridge e Bruce, (2010), no sentido de orientar os entrevistados para o fenômeno em questão e tentar minimizar as dificuldades em lidar com um conceito abstrato.

Diante da análise das dificuldades encontradas no pré-teste e buscando minimizá-las, foram realizadas algumas alterações no roteiro da entrevista, que passou a contar com quatro questões, conforme apresentado no Quadro 04. 


\section{Roteiro da Entrevista}

Introdução: - A pesquisa é sobre os entendimentos e experiências de bibliotecários que trabalham em bibliotecas públicas. Eu vou fazer algumas perguntas relacionadas às suas percepções e à sua experiência profissional. Sinta-se à vontade para abordar todos os aspectos que você considerar relevantes. Nenhum entrevistado será identificado e todos os dados serão mantidos sob confidencialidade. Nossa conversa será gravada para facilitar a análise, posteriormente. Você está de acordo?

1. Descreva com base na sua experiência qual é a missão e o papel do bibliotecário que trabalha em biblioteca pública.

2. Na sua opinião o que significa dizer que um usuário sabe lidar de forma eficaz com a informação?

3. O que você faz ou que serviços presta para capacitar os usuários da sua biblioteca para lidar de forma eficaz com a informação?

4. Na sua opinião qual o papel do letramento informacional no seu trabalho como bibliotecário de biblioteca pública?

Finalização. - Agradecimento.

Quadro 4: Roteiro da Entrevista

Elaboração própria

Como já foi citado acima, além das perguntas previamente estabelecidas neste roteiro, e no intuito de manter uma postura aberta e flexível, no decorrer das entrevistas foram feitas perguntas intermediárias ou de seguimento, de modo a direcionar para o fenômeno e encorajar a reflexão dos entrevistados. De acordo com o andamento das entrevistas foram feitas perguntas como: "Você pode falar um pouco mais sobre isso?", "O que você entende por isso? ", "Gostaria de abordar algum outro aspecto? ". Cabe ressaltar que, para que o entrevistado não se sentisse pressionado as perguntas intermediárias foram utilizadas com parcimônia.

No caso da pergunta 4 - Na sua opinião qual o papel do letramento informacional no seu trabalho como bibliotecário de biblioteca pública? - quando o entrevistado não conseguia atribuir sentido ao termo "letramento informacional", a 
pergunta era refeita utilizando-se os dois termos "letramento informacional ou competência informacional": "Na sua opinião qual o papel do letramento informacional ou competência informacional no seu trabalho como bibliotecário de biblioteca pública? " Esta conduta foi adotada a fim de maximizar o entendimento da questão por parte dos entrevistados, tendo em vista que letramento informacional e competência informacional são as formas de tradução mais recorrentes presentes na literatura de ciência da informação no Brasil para o termo original "information literacy".

Conforme Demasson, Partridge e Bruce, (2010), apesar de os entrevistados serem membros qualificados de uma profissão em que o letramento informacional é um princípio central, seria imprudente supor que todos estejam familiarizados com o conceito. Por este motivo, a questões tiveram por objetivo direcionar de forma implícita para o fenômeno, visando inicialmente medir a compreensão dos entrevistados para o que seria um "usuário capaz de lidar de forma eficaz com a informação", para apenas ao final examinar sua familiaridade com o conceito de letramento informacional (ou competência informacional) de forma explicitamente declarada.

Todos os bibliotecários que participaram da pesquisa têm ou já tiveram experiência com serviço de referência ou algum outro serviço direto ao usuário em bibliotecas públicas. As entrevistas foram agendadas previamente, para data e horário de conveniência do entrevistado e realizadas por telefone, tendo em vista a impossibilidade de serem realizadas pessoalmente devido aos custos e à logística necessária. A duração média de cada entrevista foi de dez minutos. Todas as entrevistas foram gravadas (com a anuência dos entrevistados) e transcritas integralmente para análise. Foi necessário o período de um mês para o agendamento e a realização das entrevistas.

Tanto a seleção da amostra, quanto a coleta de dados foram guiadas por diretrizes estabelecidas por teóricos e estudiosos da fenomenografia, conforme encontra-se detalhado no Quadro 5. 


\begin{tabular}{|c|c|}
\hline Diretrizes & Como as diretrizes foram aplicadas \\
\hline \multicolumn{2}{|c|}{ Seleção da Amostra } \\
\hline $\begin{array}{l}\text { A amostra reflete experiências do fenômeno } \\
\text { investigado (MARTON; BOOTH, 1997) }\end{array}$ & $\begin{array}{l}\text { Os bibliotecários selecionados para compor a } \\
\text { amostra têm experiência ou trabalham no serviço de } \\
\text { referência ou em serviços e projetos com contato } \\
\text { direto com o usuário. Durante o contato inicial, para } \\
\text { agendamento da entrevista, os entrevistados foram } \\
\text { questionados sobre sua experiência e atuação } \\
\text { profissional. }\end{array}$ \\
\hline $\begin{array}{l}\text { A amostra maximiza a variação de } \\
\text { experiências (BOWDEN, 2000) }\end{array}$ & $\begin{array}{l}\text { A amostra incluiu } 15 \text { bibliotecários oriundos das } \\
\text { cinco regiões do Brasil. A variação das experiências } \\
\text { foi buscada pela abrangência geográfica da pesquisa, } \\
\text { tendo em vista os contextos, culturas e realidades } \\
\text { distintas dos profissionais das diversas regiões e } \\
\text { estados do país. }\end{array}$ \\
\hline $\begin{array}{l}\text { A amostra inclui um número adequado de } \\
\text { entrevistados (TRIGWELL, 2000) }\end{array}$ & $\begin{array}{l}\text { O número de } 15 \text { sujeitos participantes está dentro } \\
\text { do recomendado. }\end{array}$ \\
\hline \multicolumn{2}{|c|}{ Coleta dos Dados } \\
\hline $\begin{array}{l}\text { Assegurar que as perguntas estão } \\
\text { relacionadas diretamente com o fenômeno } \\
\text { investigado (MARTON; BOOTH, 1997) }\end{array}$ & $\begin{array}{l}\text { As perguntas foram baseadas em estudo similar } \\
\text { realizado anteriormente (DEMASSON; PARTRIDGE; } \\
\text { BRUCE, 2010) e foram orientadas ao fenômeno de } \\
\text { interesse para o estudo. }\end{array}$ \\
\hline $\begin{array}{l}\text { Fazer entrevistas flexíveis (MARTON, } \\
\text { 1981;1994) }\end{array}$ & $\begin{array}{l}\text { Apesar de contar com um conjunto predeterminado } \\
\text { de perguntas, durante a entrevista foi aberto espaço } \\
\text { para permitir o fluxo natural da conversação, à } \\
\text { medida que os entrevistados abordavam tópicos de } \\
\text { interesse, e também orientando de volta ao foco } \\
\text { quando os entrevistados fugiam ao tema. }\end{array}$ \\
\hline $\begin{array}{l}\text { Guiar o entrevistado a um estado de } \\
\text { metaconsciência (MARTON; BOOTH, 1997) }\end{array}$ & \multirow{3}{*}{$\begin{array}{l}\text { Estas três diretrizes estão relacionadas com o mesmo } \\
\text { aspecto: alcançar que o entrevistado mostre sua } \\
\text { consciência e reflita sobre a experiência. As diretrizes } \\
\text { foram observadas com a inclusão de perguntas de } \\
\text { seguimento para estimular o entrevistado a refletir e } \\
\text { elaborar melhor suas respostas baseadas nas suas } \\
\text { experiências, como por exemplo: "poderia falar mais } \\
\text { sobre isso?" ou "o que você quis dizer com isso?" } \\
\text { Além disso, optou-se por não insistir, nem pressionar } \\
\text { o entrevistado com muitas perguntas de seguimento } \\
\text { quando este parecia estar confuso. Neste caso } \\
\text { buscou-se mudar o foco da entrevista para a } \\
\text { pergunta seguinte. }\end{array}$} \\
\hline $\begin{array}{l}\text { Usar perguntas de seguimento (POSSER, } \\
\text { 2000) }\end{array}$ & \\
\hline $\begin{array}{l}\text { Evitar o uso excessivo de perguntas de } \\
\text { seguimento (TRIGWELL, 2000) }\end{array}$ & \\
\hline
\end{tabular}

Quadro 5: Diretrizes para a seleção da amostra e coleta de dados Fonte: Adaptado de GONZÁLEZ-UGALDE, 2014 


\subsection{MÉTODO DE ANÁLISE DOS DADOS}

Após a coleta dos dados, a parte mais desafiadora da pesquisa fenomenográfica é a análise das transcrições literais das entrevistas. As transcrições constituíram o material empírico para a análise qualitativa, com o objetivo de identificar e distinguir as experiências, percepções, conceitos e/ou entendimentos qualitativamente diferentes de modo a enquadrá-los em um número limitado de categorias (MARTON, 1981; MARTON, 1994).

Para a análise dos dados foram consideradas as sete etapas de Dahlgren e Fallsberg (1991), empregadas no estudo de Sjöström \& Dahlgren (2002):

1- Etapa de familiarização: as transcrições foram lidas várias vezes, visando a familiarização com o seu conteúdo. Nesta etapa foram corrigidos eventuais erros na transcrição.

2- Etapa de compilação: A segunda etapa exigiu uma leitura mais focada, a fim de deduzir semelhanças e diferenças em relação às transcrições. Através deste processo, foi possível identificar os elementos mais valorizados nas respostas.

3- Etapa de condensação: Este processo visou à seleção de extratos relevantes e significativos para o estudo. O objetivo principal desta etapa é filtrar e omitir os componentes irrelevantes, redundantes ou desnecessários dentro da transcrição e, consequentemente, decifrar os elementos centrais das respostas dos participantes.

4- Etapa de agrupamento preliminar: a quarta etapa implicou em agrupamento preliminar ou classificação das respostas semelhantes. Assim, a análise apresentou uma lista inicial de categorias.

5- Comparação preliminar de categorias: esta etapa envolveu a revisão da lista inicial de categorias a fim de possibilitar uma comparação entre as categorias preliminares. O principal objetivo desta etapa foi estabelecer fronteiras entre as categorias. Antes de ir para a próxima etapa, as transcrições foram lidas novamente para verificar se as categorias preliminares estabelecidas representavam a experiência exata dos participantes.

6- Nomeação das categorias: Após a confirmação das categorias, o próximo passo foi de nomear as categorias para enfatizar sua essência baseada em atributos internos dos grupos e distinguir características entre eles. Foram identificados os pontos presentes em todas as entrevistas e que influenciavam a sua variação (dimensões de variação). 
7- Resultado final: na última etapa, foi realizada uma descrição do caráter único e das semelhanças/diferenças entre as categorias (dimensões de variação). A partir da comparação foi estabelecida uma hierarquia das categorias, formando assim o espaço de resultado da pesquisa, ou seja, um número limitado de categorias de descrição, hierarquicamente relacionadas, derivadas da percepção e vivência dos bibliotecários em relação ao letramento informacional no contexto das bibliotecas públicas. 


\section{ANÁLISE DOS DADOS E DISCUSSÃO DOS RESULTADOS}

O presente capítulo trata da descrição dos dados coletados e discussão dos resultados encontrados. Como já foi exposto anteriormente, o principal objetivo de um estudo fenomenográfico é descrever e organizar as várias maneiras de experimentar um fenômeno por um grupo de indivíduos em um número limitado de categorias que se relacionam (DEMASSON, PARTRIDGE, BRUCE, 2010). Este conjunto de categorias descritivas das concepções, lógica e hierarquicamente organizadas, que refletem os modos de experimentar um fenômeno compõe o chamado espaço de resultado (outcome space), produto da pesquisa fenomenográfica.

As categorias descritivas ou modos qualitativamente diferentes de compreender um fenômeno, estão relacionadas ao significado atribuído pelos indivíduos à experiência e representam o aspecto referencial ou "o que" do fenômeno. Já as dimensões de variação representam as maneiras que os indivíduos abordam a experiência e a vontade ou intenção subjacente ao ato e representam o aspecto estrutural do fenômeno ou o "como" da experiência.

É importante salientar que, a despeito da experiência ser formada por aspectos referenciais e estruturais ou categorias de descrição que variam em decorrência das dimensões de variação, o conjunto dos aspectos que formam a experiência são intrinsicamente relacionados e vivenciados simultaneamente (MARTON; BOOTH, 1997 apud GONZÁLEZ-UGALDE, 2014). O espaço de resultado representa a variação nas formas coletivas de experimentar um fenômeno e não busca, portanto, a descrição da experiência individual e sim desvendar a anatomia da consciência coletiva (MARTON, 2007 apud GONZÁLEZ-UGALDE, 2014).

Ou seja, o espaço de resultado é formado pelo conjunto das categorias descritivas (concepções), pela relação hierárquica inclusiva entre as concepções e pelas dimensões de variação, que indicam as semelhanças, diferenças e relações entre as categorias. No presente estudo, o espaço de resultado abrange quatro categorias e uma subcategoria, que descrevem as concepções de letramento informacional a partir da perspectiva de um grupo de bibliotecários de bibliotecas públicas estaduais do Brasil, a relação hierárquica entre essas categorias e cinco dimensões de variação em torno das quais variam as concepções.

O espaço de resultados é apresentado a seguir, subdividido em três tópicos: Categorias de descrição, onde são descritas as distintas concepções de letramento 
informacional em bibliotecas públicas; Dimensões de variação que apresenta as variações, semelhanças e diferenças entre as categorias de descrição; e Estrutura hierárquica, que aborda a relação hierárquica entre as categorias de descrição identificadas.

\subsection{CATEGORIAS DE DESCRIÇÃO}

A fenomenografia pressupõe que um mesmo sujeito pode perceber determinada experiência - neste caso, o letramento informacional - de formas diferentes. Ou seja, as experiências e percepções relatadas por um indivíduo podem ser classificadas em diferentes categorias de descrição. As categorias, por sua vez, são compostas por descrições formuladas pelo pesquisador a partir do processo de análise dos dados.

Neste estudo, quatro categorias distintas e uma subcategoria foram identificadas. Estas categorias são resultado de um processo iterativo de análise do conjunto de dados obtidos e da interpretação da pesquisadora. Cada uma descreve uma forma única em que pelo menos mais de um dos participantes da pesquisa experimentam ou compreendem o fenômeno em questão, as atitudes e opiniões expressas pelos entrevistados sobre o letramento informacional no contexto das bibliotecas públicas, quais sejam:

- Categoria 1: Ausência de significado

- Categoria 2: Necessidade de informação

- Categoria 3: Fontes ou Recursos de informação Subcategoria 3A: Resultado

- Categoria 4: Socialização do conhecimento

Trechos das transcrições das entrevistas foram utilizados como evidências empíricas para ilustrar aspectos relevantes que dão sentido e significado às categorias. Cabe destacar que as citações têm função ilustrativa e não representam, necessariamente, todos os elementos abordados nas categorias.

Assim como ocorreu no estudo desenvolvido por Demasson, Partridge e Bruce (2010), é prudente afirmar que as categorias que emergiram nesta pesquisa não devem ser consideradas definitivas ou exaustivas e não possibilitam 
generalização. Ou seja, as categorias descritivas aqui apresentadas, refletem as concepções dos bibliotecários que participaram da pesquisa. No entanto, é possível afirmar que os resultados indicam, potencialmente, tendências mais amplas relacionadas à compreensão e vivência dos bibliotecários de bibliotecas públicas brasileiras sobre o letramento informacional.

As categorias descritivas são apresentadas abaixo de forma semelhante à utilizada por Demasson, Partridge e Bruce (2010) indicando o nome designado para a categoria, seu significado e foco, além das citações ilustrativas e uma breve descrição e análise de cada categoria.

Categoria1: Ausência de significado.

Significado: Não consegue atribuir um significado ao conceito.

Foco: Falta de envolvimento com o conceito de letramento informacional.

\section{Citação ilustrativa:}

(Entrevistado 8): “O letramento informacional é praticamente um bebê, está começando agora, então muita gente não sabe o que é."

Nesta categoria, os respondestes não conseguem atribuir significado ao conceito, mesmo com a utilização das perguntas de seguimento, que buscaram orientar os entrevistados para o fenômeno conforme sua narrativa no decorrer das entrevistas. Apesar de serem questionados mais de uma vez, desviaram suas respostas para outros assuntos ou apresentaram respostas vagas, como "é muito importante" (Entrevistado 5), mas sem conseguir discorrer sobre o porquê da importância.

Embora o letramento informacional seja um conceito inerente à área de atuação do bibliotecário, e a despeito desta pesquisa considerar que todos os participantes têm relação e/ou experiência com o fenômeno, essa concepção emergiu do conjunto dos dados analisados. Esta categoria também foi identificada no estudo de Demasson, Partridge e Bruce (2010). Para os autores, esta categoria significa falta de vontade de se envolver com o conceito e sugere um processo ativo de evasão e negação e embora possa parecer possível que haja uma verdadeira ausência de conhecimento sobre letramento informacional, o que está em evidência não é a consciência do conceito, mas a recusa em constituí-lo, o que por sua vez, ilustra uma recusa ativa de se envolver com a informação.

No caso do presente estudo, é possível afirmar que esta categoria pode 
denotar falta de identificação e negação, mas esse comportamento evasivo também pode ser um indicador de falta de conhecimento sobre o conceito. Este é um resultado importante e ao mesmo tempo alarmante, pois como exposto anteriormente o letramento informacional é um conceito inerente à área de atuação dos bibliotecários e se apresenta como em elemento essencial para o desempenho das bibliotecas públicas no contexto atual e futuro.

Autores como Julien e Hoffman (2008) identificaram a falta de identificação do bibliotecário com o papel educativo como um dos principais entraves para o efetivo desenvolvimento do letramento informacional nas bibliotecas públicas. GomezHernandez e Pasadas-Ureña (2007) também identificaram, dentre outros, problemas relacionados aos profissionais e suas concepções e competências, como:

a) Falta de conhecimento sobre as questões relacionadas ao letramento informacional, o que torna necessária a realização de campanhas de conscientização e informação, previamente à realização das atividades de letramento informacional, voltadas para autoridades, agentes sociais e público em geral;

b) Deficiências na formação dos profissionais em competências e habilidades para promover a aprendizagem e o letramento informacional. Pouca reflexão sobre a necessidade de incluir essa pauta nos currículos das Universidades ou nas associações profissionais.

Isso implica em sérias reflexões, inclusive sobre a formação do bibliotecário. A construção de significado do conceito de letramento informacional por parte dos bibliotecários de bibliotecas públicas permeia a abordagem do tema nos currículos dos cursos de graduação, nas discussões de classe, em cursos de educação continuada e em campanhas de conscientização. Mas, antes de tudo, deve partir de uma predisposição pessoal dos bibliotecários à mudança e a uma atitude eminentemente proativa.

É importante manter postura e olhar atentos aos sinais e às transformações permanentes da profissão e das instituições, a fim que o profissional tenha clareza da natureza e amplitude do seu papel e possa fazer frente a essas mudanças. Como destaca Elmborg (2006), é essencial desenvolver uma consciência crítica e aprender a fazer perguntas sobre o papel da biblioteca e do bibliotecário.

Para que os bibliotecários possam construir significado para o letramento informacional no contexto das bibliotecas públicas eles mesmos devem estar engajados num processo pessoal de letramento informacional, que envolve uma 
atitude reflexiva, o aprender a aprender, a aprendizagem permanente, a socialização do conhecimento. Como exposto por Tarapanoff, Suaiden e Oliveira(2002), para educar os outros o bibliotecário terá que antes educar a si mesmo. Ainda neste sentido, Elmborg (2006) destaca que o bibliotecário só será capaz de ajudar a realizar a viagem ou percorrer o caminho intelectual, se eles mesmos forem capazes de fazê-lo.

Categoria 2: Necessidade de informação.

Significado: O letramento informacional é constituído como a capacidade de reconhecer e expressar com clareza uma determinada necessidade de informação.

Foco: Ser capaz de reconhecer e expressar uma necessidade de informação.

Citações ilustrativas:

Entrevistado 9: "É quando a pessoa sabe realmente o que quer. "

Entrevistado 3: "Alguns usuários vêm em busca de uma informação, mas não sabem dizer exatamente o que querem, é preciso conversar, estabelecer um diálogo para conseguir identificar o que ele realmente quer. "

Entrevistado 4: "Às vezes vem [os usuários] em busca de uma informação que nem eles mesmo sabem o que é, o bibliotecário precisa ser um pouco intérprete.”

Entrevistado 12: “Nós temos uma grande dificuldade em relação ao próprio profissional da informação, eles não conseguem interpretar o que o usuário está precisando. "

Essa concepção representa o entendimento mais raso dentre os identificados no conjunto dos dados analisados. Nesta visão, o letramento informacional constituise simplesmente em ser capaz de reconhecer uma determinada necessidade de informação e saber expressar essa necessidade a alguém que irá mediar o restante do processo de busca, localização e avaliação da informação. Reflete uma postura passiva do bibliotecário e da biblioteca pública, em que a sua atuação se inicia e decorre de uma provocação do usuário, que desprovido de habilidades e competências no manejo da informação necessita que alguém lhe entregue respostas prontas.

Um dos principais componentes do letramento informacional, que é a autonomia, não é contemplada nesta concepção. No cerne desta categoria encontrase a ideia de que o papel principal da biblioteca pública é informar e não formar. Neste sentido, o processo de mediação que poderia tornar-se educativo e transformador acaba sendo meramente informativo. 
Esta concepção reflete ainda, uma visão bastante tradicional do papel da biblioteca pública e do bibliotecário, centrado na transferência de informações. Elmborg (2006) critica esse posicionamento ao afirmar que os bibliotecários deveriam se preocupar mais com a formação da consciência crítica das pessoas, de modo que estes se tornem capazes de formular e responder às próprias perguntas e menos na transferência de conhecimento.

Como as concepções baseiam-se na experiência destes bibliotecários, podese inferir também acerca do despreparo dos usuários que frequentam as bibliotecas públicas. Ou seja, há uma demanda latente por formação para o acesso à informação, que só poderá ser atendida a partir de uma mudança de postura do bibliotecário e do desenvolvimento de ações conjuntas entre a biblioteca pública e outras instituições.

É importante, mais uma vez, que o bibliotecário tenha uma postura proativa e não apenas reativa, a partir da consciência que sua atuação se inicia antes mesmo que o usuário expresse uma necessidade e que continua após a localização da informação desejada. É necessário antecipar-se a essas necessidades, como propõe Milanesi (1986), tornando a biblioteca pública um espaço conectado às necessidades latentes e demandas que ainda não foram expressas, um espaço de discussão e questionamento, que aponte novas possibilidades e propicie novas compreensões. Ou seja, que vá além da mera função informativa.

Categoria 3: Fontes ou Recursos de Informação.

Significado: O letramento informacional é constituído como o conhecimento das fontes e recursos de informação e a capacidade de avaliação da informação.

Foco: Ser capaz de selecionar as fontes e avaliar a informação.

Citações ilustrativas:

Entrevistado 2: "[...] saber como ter acesso à informação necessária na biblioteca ou no mundo digital, saber o que a biblioteca oferece, material impresso, on-line, quais as funcionalidades e a segurança que essas fontes oferecem, saber avaliar qual é confiável."

Entrevistado 13: "Ter entendimento e interpretação para avaliar a informação, saber como fazer uma pesquisa, quais são os sites confiáveis. "

Entrevistado 9: "Conhecer os recursos da biblioteca, saber como fazer uma pesquisa. "

Nesta concepção, o indivíduo engajado no processo de letramento informacional conhece os recursos oferecidos pela biblioteca, bem como outras fontes 
de informação, como aquelas em meio digital. Além disso, é capaz de utilizá-las para a busca da informação, assim como tem a capacidade e o discernimento para avaliar as informações encontradas, sua validade e confiabilidade. Bruce (1997), também identificou essa concepção no seu estudo "sete faces do letramento informacional", que conforme a autora envolve o conhecimento de fontes em variados formatos, já que é o conhecimento das fontes que possibilita a recuperação de informações contidas nas fontes.

Apesar de estar fundamentada na função informativa da biblioteca pública, esta categoria também traz em seu bojo elementos de uma visão da função educativa, uma vez que além de abordar o conhecimento das fontes de informação, centra-se em competências e habilidades relacionadas à seleção e avaliação da informação. Nesta categoria, o estímulo para se envolver com informações é desencadeado não só pela necessidade de saber onde informações podem ser encontradas, mas também pela necessidade de avaliá-la criticamente. Segundo esta concepção é papel do bibliotecário apresentar ao usuário a biblioteca, os recursos e fontes disponíveis, demonstrar como acessar os recursos e avaliar a validade e confiabilidade dessas fontes. Lloyd (2005), critica isso que chama de "paradigma dominante do letramento informacional", que enfatiza a importância de conectar-se com a informação textual, o que produz um modelo deficiente que não leva em conta a importância do aprendizado informal ou outras fontes de informação que são acessadas pela comunicação ou pela ação.

Esta categoria evidencia um importante elemento do letramento informacional: a capacidade crítica (utilizada para avaliar a informação e as fontes), não obstante, outros elementos importantes, como aqueles relacionados ao uso e aplicação da informação são negligenciados nesta concepção. Aspectos éticos do uso da informação também não foram mencionados durante as entrevistas. É como se o processo se encerrasse na busca e seleção da informação, já que aspectos relacionados ao seu uso não são mencionados, ou por serem tidos como irrelevantes ou secundários ou mesmo por não considerarem estes como preocupações do bibliotecário ou da biblioteca pública.

Categoria 3A: Resultado.

Significado: O letramento informacional constitui-se como o resultado de um processo, onde o indivíduo é capaz de localizar a informação que ele precisa de modo 
independente.

Foco: Ser capaz de localizar a informação desejada com autonomia.

\section{Citações ilustrativas:}

Entrevistado 15: "Ele [o indivíduo engajado no processo do letramento informacional] é independente e consegue alcançar o desejado. "

Entrevistado 11: "Letramento informacional é justamente isso, ensinar o usuário a ser o mais independente possível para que ele encontre o que veio buscar. "

Esta subcategoria, é bem próxima da concepção apresentada na categoria 3, no entanto, há destaque para dois elementos que não figuram de forma explícita na categoria principal. Enquanto na categoria 3 o foco reside nos recursos e fontes de informação, a subcategoria $3 \mathrm{~A}$ destaca a independência do usuário durante 0 processo e o alcance de um resultado como o foco em questão. Apesar de o conhecimento das fontes pressupor a independência do usuário, este elemento ganhou destaque de forma explícita e evidente nesta concepção.

Bruce (1997) subdividiu a concepção baseada nas fontes de informação em três categorias: conhecer as fontes e suas estruturas, conhecer as fontes de informação e usá-las com independência e conhecer as fontes de informação e usálas com flexibilidade, seja de forma independente ou por mediação. Traçando um paralelo com a subdivisão de Bruce é possível afirmar que na categoria 3 o uso das fontes poderia ser feito de forma flexível, ou seja, também por mediação, enquanto na subcategoria 3A pressupõe-se a independência.

Nesta visão o letramento informacional seria a capacidade de localizar a informação desejada com autonomia. Vai um pouco além da categoria 3 por expressar mais claramente o alcance do resultado e por abarcar além do conhecimento das fontes, outras competências como a capacidade de elaborar uma estratégia de busca eficaz. O estímulo para se engajar no processo é o alcance de um resultado a partir de um processo autônomo de busca da informação. No entanto, também deixa de lado aspectos referentes ao uso da informação.

Categoria 4: Socialização do conhecimento.

Significado: O letramento informacional se constitui como a capacidade de gerar um novo conhecimento ou um benefício a partir do uso da informação.

Foco: Ser capaz de produzir um novo conhecimento ou um benefício para si ou para sua comunidade a partir do uso da informação. 


\section{Citações ilustrativas:}

Entrevistado 10: "É a capacidade de utilizar a informação de maneira correta [...] aplicar a informação para gerar um novo conhecimento, para a solução de um problema do seu dia a dia, para a melhoria da sua comunidade. O letramento informacional permite que as pessoas tenham condições para argumentar, questionar, buscar melhorias e exercer a cidadania. "

Entrevistado 6: "É ser capaz de assimilar, de entender o que determinada informação transmite, interpretar de maneira correta e transformar essa informação em um novo conhecimento."

Esta foi a concepção mais profunda que emergiu dos dados analisados. Abrange elementos relacionados ao uso da informação, que não estiveram presentes nas concepções anteriores, e seus efeitos, tais como gerar novos conhecimentos, exercer um direito ou resolver um problema.

Apresenta uma visão mais holística do processo de letramento informacional, já que não estabelece a busca ou o acesso à informação como um fim em si mesmo, mas como uma necessidade gerada a partir de um contexto em que o seu uso implica em transformações neste mesmo contexto. Observou-se que essa concepção está relacionada a uma percepção mais voltada para a função social e educativa dos bibliotecários e da biblioteca pública. Nesta concepção a biblioteca é um espaço de aprendizagem e conexão social.

Segundo essa visão, a biblioteca pública apresenta-se como lugar de acolhimento e encontro reflexivo, espaço de encontro e construção de novos conhecimentos, a partir do suporte tecnológico e informacional que pode ofertar (CRIPPA, 2015). Ou seja, não significa uma negação da função informativa da biblioteca, mas utilizar a informação para formar (gerar aprendizado) e principalmente para gerar novos conhecimentos.

Nesta categoria, o letramento informacional não é visto apenas como um conjunto de habilidades para acessar informações, mas como uma experiência mais orgânica, que considera elementos do contexto, e na qual o resultado é a socialização do conhecimento a partir do uso transformador da informação. Esta concepção é a mais próxima do conceito de letramento informacional em bibliotecas públicas presente no referencial teórico adotado por este estudo, em que engajar-se no processo de letramento informacional significa resolver problemas, buscar soluções, de forma crítica e contextualizada e voltada para a ação, ou a práxis (HALL, 2009). 
Esta concepção guarda semelhanças com a categoria "Social" identificada no estudo de Demasson, Partridge e Bruce (2010), onde o estímulo para se envolver com informações é desencadeado por uma necessidade inata do indivíduo de se engajar com o mundo social em que vive. Ao invés de ser visto simplesmente como um meio para alcançar um determinado objetivo, ou como habilidades especiais que podem ser adquiridas, o letramento informacional é visto como uma função necessária para a vida.

\subsection{DIMENSÕES DE VARIAÇÃO}

A identificação de aspectos presentes em todas as categorias de descrição e que, no entanto, representam variação ou expansão da percepção sobre o fenômeno no decorrer das categorias, também faz parte do processo de análise fenomenográfica, são as chamadas dimensões de variação. No presente estudo, os modos qualitativamente diferentes de vivência e compreensão do letramento informacional em bibliotecas públicas - quatro categorias e uma subcategoria - variam entre si a partir de cinco dimensões de variação, que indicam as semelhanças, diferenças e relações entre as categorias. Estas dimensões, que representam o aspecto estrutural da experiência do letramento informacional em bibliotecas públicas são descritas a seguir e encontram-se sintetizadas no Quadro 6:

a) Quanto ao Foco: Reflete a dimensão de significado da categoria de descrição, orientado para a ação ou o que se pretende alcançar, varia progressivamente conforme as concepções tornam-se mais completas. Enquanto nas concepções mais rasas o foco reside nos processos de busca e aquisição da informação na categoria mais completa o foco está no uso da informação e em seus efeitos.

b) Intenção subjacente: Envolveu a identificação das principais intenções por trás do envolvimento com o fenômeno, conforme a visão dos bibliotecários entrevistados. Demonstra uma variação crescente das categorias de descrição.

Nas primeiras categorias a intenção ou vontade subjacente é a aquisição da informação. À medida que as categorias vão evoluindo novos elementos vão sendo incorporados até alcançar, na última categoria, a intenção de criar um novo conhecimento a partir do uso da informação.

c) Função da biblioteca pública: A forma como os bibliotecários percebem a função da biblioteca pública implica em variações no modo como concebem o letramento 
informacional neste contexto. Foram identificadas basicamente três funções no conjunto dos dados analisados: função informativa, educativa e social. As concepções mais rasas estão relacionadas a uma percepção da função informativa como a principal função da biblioteca pública e à medida que as concepções evoluem, a função educativa também é incorporada, e por fim a função social se mescla à educativa na concepção mais profunda.

Conforme a visão da função informativa, é papel da biblioteca pública: "levar a informação certa para o usuário certo no momento certo" (Entrevistado-6); "atender às necessidades de informação dos usuários" (Entrevistado-11); "tornar a informação acessível ao usuário" (Entrevistado-1); ou "democratizar o acesso à informação" (Entrevistado-5). A centralidade do papel da biblioteca pública na função informativa denota uma visão tradicional da biblioteca, a partir de uma de suas funções mais clássicas. Os bibliotecários entrevistados que demonstram forte vinculação e identificação com esta função tendem a ter uma percepção do letramento informacional mais voltado aos processos de busca e aquisição da informação.

O papel informativo faz parte da tríade essencial das bibliotecas públicas, conforme MILANESI (2002): informar, discutir e criar. No entanto, conforme o autor, essa função básica de prestar informações necessárias à coletividade por prescindir de tempo e espaço é a que mais sofrerá mudanças. Portanto, o bibliotecário deve ir além do objetivo de informar e atentar para os outros dois objetivos: discutir e criar. É salutar, neste sentido uma reflexão em torno da reconfiguração da biblioteca pública e de seus papeis.

A função educativa, se apresenta de forma um pouco incipiente nas categorias 3 e $3 \mathrm{~A}$, relacionada ao aprendizado dos recursos da biblioteca e das fontes de informação e seu manejo. Esta visão está mais voltada para os antigos programas de educação de usuários do que essencialmente para o letramento informacional, conforme salienta Gomez-Hernandez e Pasadas-Ureña (2007). Conforme estes autores, a evolução desta função deve ser uma adaptação às novas circunstâncias e exigências, com a inclusão de novos e mais amplos objetivos de aprendizagem. Aliado à função social, a função educativa parece servir a esses ideais de transformação, de um modo mais profundo, na categoria 4.

Nesta perspectiva - da função social - a biblioteca pública é o ponto de encontro, discussão e interação da comunidade, proporcionando uma experiência social. É o "local onde as pessoas podem circular livremente, viver em comunidade, 
interagir com outras pessoas" (Entrevistado-10), e ainda "conhecer, aprimorar-se, trocar experiências" (Entrevistado-6).

A vertente social é apontada por autores como Crippa (2015), Milanesi (2002; 2013), Herrera-Viedma e López-Gijón (2013), como uma das mais importantes para a atuação atual e futura das bibliotecas públicas. No entanto, ainda se observa uma forte vinculação dos bibliotecários a funções mais tradicionais. No caso do presente estudo uma percepção mais profunda do letramento informacional está associada à visão do papel social da biblioteca pública.

d) Papel do Bibliotecário: Assim como ocorre na dimensão de variação anterior o modo como os bibliotecários compreendem o seu papel implica em variações na experiência e compreensão do fenômeno.

Nas concepções menos inclusivas, o bibliotecário se vê como mediador e facilitador no acesso à informação. A visão desse processo de mediação também evolui com a ampliação do entendimento do seu papel enquanto bibliotecário. Parte de uma postura passiva, onde o bibliotecário entrega respostas prontas a quem as solicita, passando por um processo de mediação mais educativo em que o bibliotecário direciona, mostra o caminho e ensina como trilhá-lo.

Segundo esta visão o bibliotecário é "um direcionador de ideias, que ensina o caminho que o usuário pode percorrer para resolver um problema ou usar os serviços de um órgão público e não necessariamente, apenas indicar leituras" (Entrevistado14) uma vez que "o bibliotecário também é um pouco professor" (Entrevistado-4). Ressalta-se ainda o caráter de troca e interação com o usuário, ao afirmar que "o bibliotecário também pode aprender com o usuário" (Entrevistado-14). Na concepção mais completa, o bibliotecário assume como responsabilidade a função de educador e a dimensão do uso do e socialização do conhecimento.

Uma vez que a consciência do bibliotecário de seu papel educativo está relacionada a concepções mais profundas de letramento informacional, cabe destacar a recomendação de Elmborg (2006), segundo o qual, é necessário que a formação do bibliotecário o prepare mais diretamente para cobrir essas novas funções educativas. Gasque (2012) também preconiza que os bibliotecários devem ir além do paradigma de acesso à informação, para um paradigma pedagógico, o que significa ir além da disponibilização da informação ao envolvimento com a comunidade em ações que possibilitem interpretar e transformar a informação em conhecimento.

e) Ações de promoção do letramento informacional desenvolvidas pelos Bibliotecários: 
As diversas atividades e ações promovidas pelos bibliotecários refletem o grau de comprometimento, compreensão e vivência do letramento informacional e variam conforme as concepções sejam mais rasas ou mais profundas.

Na categoria de descrição 2: Necessidade de informação, a única atividade desenvolvida é a orientação individual, ou seja, o serviço de referência, que se caracteriza por ser um trabalho realizado por demanda, com o atendimento aos usuários que buscam a ajuda do bibliotecário. Resultado semelhante ao encontrado no estudo realizado por Julien e Hoffman (2008), sobre letramento informacional nas Bibliotecas Públicas do Canadá. As autoras verificaram que as bibliotecas ofereciam instrução informal no serviço de referência ou atendimento ao cliente e que pouca instrução formal era oferecida pelas bibliotecas públicas.

Nas categorias 3 e 3A as ações desenvolvidas - visitas guiadas, orientações para usar os recursos da biblioteca e as fontes de informação - remetem ao serviço de educação de usuários, que é considerado uma expansão do serviço de referência (CAMPELLO, 2009). Mas, conforme Gomez-Hernandez e Pasadas Ureña (2007), um programa de letramento informacional é uma evolução dos programas de educação de usuários e deve ir além das atividades tradicionais, como visitas guiadas, assistência personalizada e guias de recursos.

$\mathrm{Na}$ categoria 4, figuram:

- Atividades de ação cultural, a partir das quais "os usuários podem construir suas próprias ideias e conhecimentos" (Entrevistado-1). Isso vai de encontro às considerações de Milanesi (2002), para quem a ação cultural é mais que a mera realização de eventos ou apresentações culturais, mas envolve a participação dos sujeitos e a construção de significados e conhecimentos e por isso abarca duas das funções principais da trilogia essencial das bibliotecas públicas: discutir e criar.

- Ações de incentivo à leitura. De acordo com a IFLA/UNESCO (2012), se as crianças forem estimuladas desde cedo pela "emoção causada pelo conhecimento e pelas obras da imaginação", provavelmente aproveitarão esses elementos essenciais em seu desenvolvimento pessoal por toda a vida. Pode-se afirmar, que o hábito da leitura é determinante para o desenvolvimento do letramento informacional, uma vez que o leitor crítico certamente se tornará um usuário eficaz da informação e terá condições de manter-se em desenvolvimento ao longo da vida.

- Cursos diversos voltados para públicos específicos, como portadores de necessidades especiais, idosos ou em parceria com escolas. Além da incorporação 
de atividades de formação ao ambiente da biblioteca, ponto importante ressaltado por Gomez- Hernandez e Pasadas-Ureña (2007), cabe ressaltar aqui a segmentação de público defendida por Suaiden (2010), que argumenta que ao invés de tentar ser "tudo para todos", a biblioteca pública buscar conhecer e atender a demandas específicas de determinados segmentos da comunidade;

- Serviço de informação utilitária: Fornecimento de informações para a resolução de problemas práticos do dia-a-dia, como por exemplo informações sobre como abrir uma conta no banco. O entrevistado 14 chama essa prática de mediação social: "às vezes somos abordados por pessoas que só tem a gente para fazer essa mediação social, direcioná-lo para um órgão público, ou para algo que ela esteja precisando, não necessariamente, leitura".

- Prover/democratizar o acesso às tecnologias: Além de promover a inclusão digital dos membros de suas comunidades pelo acesso às tecnologias, as bibliotecas devem abraçar o seu papel no desenvolvimento de habilidades e competências para acessar e usar a informação por meio das tecnologias de informação e comunicação.

As poucas ações citadas pelos entrevistados neste sentido, estão vinculadas à concepção 4, em geral relacionadas à orientação individual para o acesso, busca e uso da informação na internet. Mas existem algumas iniciativas que vão além disso, como no caso citado pelo Entrevistado-10: "Desenvolvemos um curso em parceria com a Secretaria de Ciência e Tecnologia do Estado, que acontece na biblioteca pública, onde as pessoas podem aprender a criar aplicativos para a melhoria do seu dia a dia".

Ainda que na concepção mais profunda figurem um maior número de atividades desenvolvidas pelos bibliotecários em prol do desenvolvimento do letramento informacional, não foi identificado nenhum programa ou conjunto de ações formalmente instituído para este fim nas entrevistas realizadas. Ou seja, os bibliotecários de bibliotecas públicas entrevistados, apesar de desenvolverem atividades e serviços que podem contribuir para o desenvolvimento do letramento informacional dos membros de sua comunidade ainda não o fazem com esse objetivo específico, de forma consciente, planejada e organizada. Para alcançar este intento será necessária uma mudança de discurso, atitudes, valores e práticas, de modo que seja possível desempenhar papeis tradicionais sob uma nova perspectiva e que os bibliotecários deixem de ser meros provedores de serviços e convertam-se em educadores ativos, tal como propõe Elmborg (2006). 


\begin{tabular}{|c|c|c|c|c|c|}
\hline $\begin{array}{l}\text { Dimensões de } \\
\text { Variação }\end{array}$ & \multicolumn{5}{|c|}{ Categorias de Descrição } \\
\hline Foco & $\begin{array}{l}\text { Falta de envolvimento } \\
\text { com o conceito de } \\
\text { letramento informacional }\end{array}$ & $\begin{array}{l}\text { Reconhecer e } \\
\text { expressar uma } \\
\text { necessidade de } \\
\text { informação }\end{array}$ & $\begin{array}{l}\text { Selecionar as fontes } \\
\text { e avaliar a informação }\end{array}$ & $\begin{array}{l}\text { Ter habilidades para } \\
\text { localizar a informação } \\
\text { necessária com } \\
\text { autonomia }\end{array}$ & $\begin{array}{l}\text { Produzir um novo } \\
\text { conhecimento ou um } \\
\text { benefício a partir do uso da } \\
\text { informação. }\end{array}$ \\
\hline $\begin{array}{l}\text { Função da Biblioteca } \\
\text { Pública }\end{array}$ & Informativa & Informativa & Informativa/Educativa & Informativa/Educativa & Educativa/Social \\
\hline Papel do Bibliotecário & $\begin{array}{l}\text { Informar/Mediar o } \\
\text { acesso à informação }\end{array}$ & $\begin{array}{l}\text { Informar/Mediar o } \\
\text { acesso à informação }\end{array}$ & $\begin{array}{c}\text { Ensinar sobre fontes } \\
\text { e avaliação da } \\
\text { informação }\end{array}$ & $\begin{array}{l}\text { Ensinar estratégias de } \\
\text { busca e localização da } \\
\text { informação }\end{array}$ & $\begin{array}{c}\text { Promover atividades que } \\
\text { fomentem o aprendizado } \\
\text { informacional, a reflexão e a } \\
\text { geração de novos } \\
\text { conhecimentos. }\end{array}$ \\
\hline
\end{tabular}

Quadro 6: Dimensões de variação das concepções

Elaboração própria 


\subsection{ESTRUTURA HIERÁRQUICA DAS CONCEPÇÕES}

Conforme Marton (1994) qualquer que seja a situação ou o fenômeno vivenciado, é possível identificar um número limitado de formas qualitativamente diferentes e logicamente inter-relacionados em que o fenômeno ou a situação é experimentado e compreendido. Como algumas formas de vivenciar o fenômeno podem ser mais eficientes que outras, é possível estabelecer uma hierarquia entre as categorias de descrição.

A relação entre as categorias de descrição deve apresentar-se como uma estrutura hierárquica inclusiva organizada por graus crescentes de compreensão, onde as mais avançadas representam uma compreensão mais completa ou complexa do fenômeno, enquanto aquelas menos avançadas representam uma compreensão menos complexa ou completa. (MARTON; TSUI, 2004 apud GONZÁLEZ-UGALDE, 2014). Isso significa que a compreensão de letramento informacional descrita na categoria 4, que é a mais completa, inclui elementos percebidos nas primeiras categorias, o que não ocorre no contrário. Desta maneira, ao passo que cada nova categoria possui aspectos em comum com as categorias anteriores, essas também apresentam algo a mais sobre a percepção dos bibliotecários entrevistados acerca do letramento informacional nas bibliotecas públicas.

No presente estudo foram identificadas quatro categorias de descrição e uma subcategoria, que caracterizam as formas qualitativamente diferentes de vivência e entendimento do letramento informacional pelos bibliotecários entrevistados e que estão relacionadas numa estrutura hierárquica inclusiva. A relação entre as categorias forma uma hierarquia onde há, gradativamente, um aumento na complexidade de entendimento do letramento informacional, ou seja, aspectos do fenômeno são percebidos simultaneamente nas categorias mais elevadas. Deste modo, a categoria 4, Socialização do Conhecimento, representa o modo de vivência mais profundo do fenômeno no grupo estudado, uma vez que é aquele que agrega mais aspectos associados à experiência do letramento informacional.

A hierarquia e a ordenação das categorias emergiram a partir de um processo iterativo no qual foram buscados indícios ou evidências lógicas e empíricas da relação inclusiva entre as categorias. As evidências lógicas são representadas pelas cinco dimensões de variação. As variações das duas primeiras dimensões: foco e intenção subjacente evidenciam uma crescente ampliação na percepção dos bibliotecários 
sobre o letramento informacional. As variações das demais dimensões enfatizam a variação sobre a concepção que os bibliotecários têm do seu papel e do papel da biblioteca pública e as ações desenvolvidas. As dimensões de variação refletem ainda as diferenças e semelhanças entre as categorias.

Como indícios empíricos foram selecionadas citações das transcrições das entrevistas que evidenciam a inclusão sucessiva de novos elementos em cada nova categoria e a inclusão de aspectos das categorias anteriores nas categorias seguintes, ou seja, que representam uma hierarquia inclusiva das categorias. Deste modo, são apresentados a seguir, trechos das entrevistas, com o objetivo de demonstrar as evidências empíricas de simultaneidade de elementos presentes na percepção dos bibliotecários ao descrever a sua experiência com o letramento informacional nas bibliotecas públicas:

a) Exemplo de simultaneidade de elementos da Categoria 2: Necessidade de informação, na Categoria 3: Fontes de Informação:

Entrevistado 5: "Eu acho que [o letramento informacional] é já chegar sabendo o que quer, mas também saber fazer uso das ferramentas para buscar a informação. ”

b) Exemplo de simultaneidade de elementos da Categoria 2: Necessidade de informação e da Categoria 3: Fontes de Informação na Subcategoria 3A: Resultado:

Entrevistado 11: "Ele [o indivíduo engajado no processo de letramento informacional] sabe expressar aquilo que quer, suas perguntas são mais concretas, ele já entende toda a dinâmica da biblioteca, ele usa os recursos da forma mais independente possível e consegue alcançar o resultado pretendido. "

c) Exemplo de simultaneidade de elementos da Categoria 2: Necessidade de informação; Categoria 3: Fontes de Informação e Subcategoria 3A: Resultado na Categoria 4: Socialização do Conhecimento:

Entrevistado 14: "É a capacidade de buscar a informação seja onde for, é ser capaz de filtrar a informação e avaliar que nem toda informação é válida. É ser capaz de usar essa informação para a necessidade que se tem no momento, para resolver um problema." 
A Figura 8 representa de forma ilustrativa a organização das categorias de descrição em uma estrutura hierárquica inclusiva.

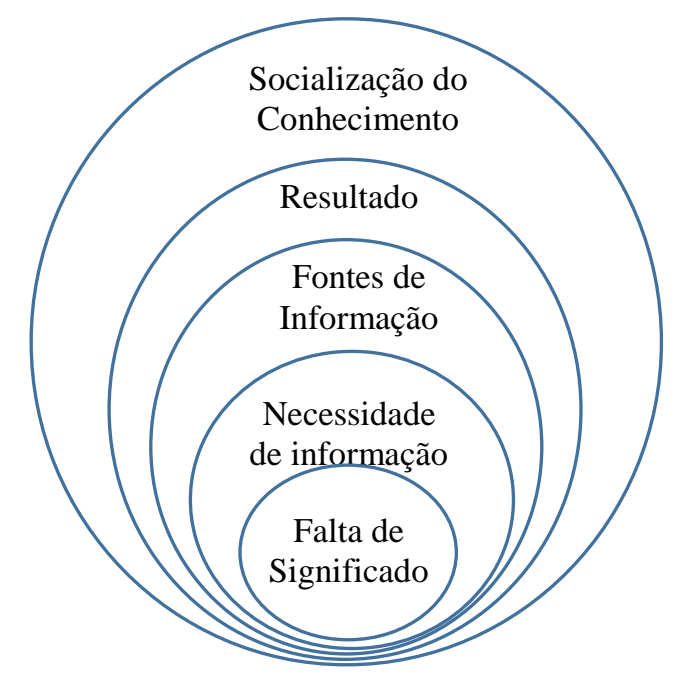

Figura 8: Estrutura hierárquica das concepções

Fonte: Elaboração própria

\subsection{ALÉM DA FENOMENOGRAFIA}

A despeito da análise fenomenográfica apresentada acima, foram observados alguns elementos no conjunto das transcrições das entrevistas realizadas que por sua relevância e relação com as discussões apresentadas na revisão de literatura merecem ser discutidas em um tópico a parte. São eles: pouca referência ao desenvolvimento de trabalho colaborativo com outras instituições e o destaque dado aos bibliotecários entrevistados ao caráter universal da biblioteca pública.

O trabalho cooperativo realizado pela biblioteca pública em parceria com outras instituições foi um dos pontos de destaque da revisão de literatura, sendo ressaltado por autores como Elmborg (2006), Harding (2008), Lai (2011) e Hall (2010), como reflexo da capacidade de engajamento e penetrabilidade da biblioteca pública no cumprimento de seu papel social e educativo, e, no entanto, foi um tema negligenciado pelos entrevistados. Poucas experiências de parcerias e cooperação foram citadas durante as entrevistas, sendo as parcerias com escolas a mais recorrente nos relatos.

Por fim, mais um ponto que merece destaque é que mais de $50 \%$ dos entrevistados ressaltaram o caráter universal e democrático da biblioteca pública, ao 
afirmar que o seu principal papel é atender toda a comunidade sem distinção. Os bibliotecários que assim se expressaram consideram que é missão da biblioteca pública: "atender a qualquer tipo de leitor" (Entrevistado-15), "independente de classe, sem nenhuma restrição" (Entrevistado-13). Alguns entrevistados reconhecem essa como sendo sua principal missão, mas afirmam ter dificuldades para cumpri-la, a partir de afirmações como: "a biblioteca pública é a mais difícil de se trabalhar, por ser heterogênea e atender a todos os públicos" (Entrevistado-2); e "é uma das bibliotecas mais complexas que existem pois atende a todo tipo de usuário" (Entrevistado-1).

Conforme previsto no Manifesto da IFLA/UNESCO (1994), a biblioteca pública "[...] por meio de uma variada gama de recursos e serviços, se coloca à disposição, de modo igualitário, a todos os membros da comunidade, independente de raça, nacionalidade, idade, gênero, religião, língua, dificuldade física, condição econômica e social e nível de escolaridade". No entanto, como expõe Suaiden (2000), há a necessidade de segmentação de público para que a biblioteca púbica não se perca tentando ser "tudo para todos".

\subsection{LIMITAÇÕES DO ESTUDO}

Quanto à realização das entrevistas por telefone, observou-se que gera um certo desconforto aos entrevistados que demonstram-se pouco à vontade com a situação. A tensão gerada pode, de certa, forma influenciar em suas respostas. No entanto, diante das restrições impostas pela pesquisa a realização de entrevistas presenciais foi inviável.

Em relação ao método fenomenográfico, como os resultados emergem essencialmente dos dados analisados e da compreensão do pesquisador, todo o processo é bastante desafiador e inquietante. Durante todo o processo há esse autoquestionamento e cobrança em ser fiel ao máximo aos dados obtidos. No entanto a análise parte do entendimento do pesquisador e, portanto, é subjetiva. Não obstante, essa é uma característica dos estudos fenomenográficos e apesar de ser uma limitação, não invalida os resultados da pesquisa.

Ademais, quanto às categorias descritivas apresentadas neste estudo, conforme já exposto anteriormente, refletem as concepções do grupo de bibliotecários que participou da pesquisa. Apesar de indicar tendências mais amplas, o resultado não é passível de generalização. 


\section{CONCLUSÃO E CONSIDERAÇÕES FINAIS}

O presente estudo teve como objetivo identificar e descrever as diferentes concepções de bibliotecários atuantes em bibliotecas públicas estaduais brasileiras sobre o letramento informacional no contexto das bibliotecas públicas. Para alcançar o objetivo proposto, a pesquisa foi pioneira ao adotar uma abordagem fenomenográfica para revelar as experiências e a compreensão de um grupo de bibliotecários de bibliotecas públicas estaduais brasileiras com o letramento informacional. O resultado foi uma visão holística do fenômeno na perspectiva destes profissionais e oportuniza uma compreensão sobre um tema pouco explorado.

No espaço de resultado da pesquisa foram identificadas quatro categorias de descrição e uma subcategoria, que caracterizam as formas qualitativamente diferentes de compreensão destes bibliotecários, que variam entre si a partir de cinco dimensões de variação. As categorias de descrição formam uma hierarquia inclusiva das concepções, que representam uma compreensão crescente do fenômeno.

Para atingir o objetivo geral, objetivos específicos foram definidos. Deste modo, é importante destacar as conclusões da investigação de acordo com os objetivos específicos determinados previamente, conforme segue abaixo:

- Objetivo Específico 1: Analisar como as concepções que os bibliotecários têm do seu papel e do papel da biblioteca pública influenciam na promoção do letramento informacional.

A forma como o bibliotecário enxerga o seu papel e a função da biblioteca pública, foram consideradas definitivas para o modo como os bibliotecários conceituam e vivenciam o letramento informacional. Concepções mais superficiais estão relacionadas à função informativa da biblioteca e do bibliotecário enquanto concepções mais profundas estão relacionadas a uma visão do papel educativo e social.

- Objetivo Específico 2: Examinar como as variações nas concepções de letramento informacional dos bibliotecários influenciam suas atividades profissionais.

Uma vez que as pessoas agem conforme sua compreensão de mundo, os resultados mostraram que os bibliotecários que compartilham de concepções de letramento informacional mais profundas desenvolveram mais ações que envolvem a socialização do conhecimento do que aqueles com concepções mais superficiais. Ainda assim, as ações ainda são muito incipientes e relacionadas com serviços 
tradicionais da biblioteca.

- Objetivo Específico 3: Mapear as possíveis ações desenvolvidas pelas bibliotecas públicas na promoção do letramento informacional.

Verificou-se que as ações desenvolvidas (Quadro 6), estão relacionadas a serviços tradicionais da biblioteca. $\mathrm{E}$, ainda que na concepção mais profunda figurem um maior número de atividades desenvolvidas pelos bibliotecários em prol do desenvolvimento do letramento informacional, não foi identificado nenhum programa ou conjunto de ações formalmente instituído para este fim nas entrevistas realizadas. Ou seja, os bibliotecários de bibliotecas públicas entrevistados, apesar de desenvolverem atividades e serviços que podem contribuir para o desenvolvimento do letramento informacional dos membros de sua comunidade ainda não o fazem com esse objetivo específico, de forma consciente, planejada e organizada.

Tornar o letramento informacional uma experiência efetiva e possível nas bibliotecas públicas, convertendo-as em espaços de aprendizagem ao longo da vida, onde seja possível não apenas aprender a usar a informação, mas aprender com a informação, passa por uma por transformação nas concepções dos bibliotecários, que deverão rever os seus valores e pensar criticamente sobre sua formação, seu papel e sua atuação.

Este trabalho representa uma das primeiras tentativas de inserção da biblioteca pública nas discussões sobre letramento informacional ou de inserção do letramento informacional nas discussões sobre a biblioteca pública no Brasil. Os possíveis motivos para a notável falta de literatura sobre essa temática começam a ser desvendadas a partir dos resultados obtidos: os bibliotecários ainda estão muito vinculados ao ideal de informar e pouco preocupados em participar ativamente da formação das pessoas.

Neste sentido, considera-se que os resultados da investigação podem ser úteis para o planejamento e execução de ações e/ou capacitações do Sistema Nacional de Bibliotecas Públicas, para os educadores que trabalham com a formação de novos bibliotecários, nas discussões curriculares dos cursos de biblioteconomia e/ou para os organismos de classe. A partir da consciência das formas que os bibliotecários compreendem o letramento informacional no contexto da biblioteca pública, estes coletivos poderão planejar atividades de formação e educação continuada, adequar ou readequar os objetivos de ensino-aprendizagem e a formação de valores dos futuros bibliotecários, ou mesmo a transformação das concepções dos 
profissionais que já estão no mercado, para que estes possam desenvolver concepções mais completas ou profundas sobre o letramento informacional.

Tendo em vista a considerável falta de pesquisas relacionando bibliotecas públicas e letramento informacional, este estudo representa uma contribuição para a literatura da Ciência da Informação e para a realização de novos estudos, visando ao preenchimento desta lacuna de conhecimento. Deste modo, os resultados obtidos também podem ser úteis para despertar o interesse de pesquisadores, que poderão realizar novas pesquisas e aprofundar o conhecimento sobre o letramento informacional no contexto da biblioteca pública, área que, de certa forma, encontra-se fora do debate letramento informacional no Brasil. E em última instância, o presente estudo pode ser útil aos próprios profissionais das bibliotecas públicas, para o exercício do autoconhecimento e aprimoramento do seu trabalho em prol do letramento informacional.

Sugere-se a realização de novas pesquisas fenomenográficas, com alterações no roteiro da entrevista ou mesmo com a elaboração de um novo conjunto de questões, conduzidas com grupos que incluam bibliotecários de bibliotecas públicas municipais e estaduais. A partir da realização de nova pesquisa o espaço de resultado poderia ser revisado, confirmado ou mesmo ampliado, a partir da identificação de novas concepções.

Uma vez que não é objeto de estudo da fenomenografia analisar a influência dos aspectos psicológicos, emocionais, culturais, sociais, políticos ou econômicos e sim a percepção dos indivíduos sobre o fenômeno, estes aspectos não foram analisados neste estudo. Mas, podem ser abordados em estudos futuros, com vistas a ampliar a compreensão do fenômeno e analisar a influência desses fatores no engajamento dos bibliotecários com o letramento informacional. O desenvolvimento de um modelo para aplicação do letramento informacional em bibliotecas públicas também teria um importante impacto teórico e prático. Representa um desafio para pesquisas futuras o desenvolvimento de modelo flexível, passível de ser adaptado e aplicado em diferentes contextos.

Por fim, pode-se inferir que, para que a biblioteca pública possa sobreviver e continuar sendo útil à sociedade, não pode ignorar todos os "sinais dos tempos" que clamam por mudanças, transformação e inovação. A sustentabilidade da biblioteca púbica dependerá de sua capacidade de gerar integração, cidadania, desenvolvimento pessoal, pensamento crítico e participação democrática a partir da 
aprendizagem informacional. O bibliotecário, por sua vez, apenas se tornará um agente de letramento informacional quando ele próprio vivenciar este processo e for capaz de analisar de forma crítica e reflexiva o seu próprio "fazer" enquanto profissional da informação. 


\title{
REFERÊNCIAS
}

ACCART, Jean-Philippe. Origem e situação atual do serviço de referência. In: Lemos/Livros, 2012.

Serviço de referência: do presencial ao virtual. Brasília: Briquet de

AMARO, Rubens de Araújo; BRUNSTEIN, Jannete. Implicações das concepções de empreender para o desenvolvimento da competência empreendedora. R. Adm.

FACES Journal, Belo Horizonte v. 12 n. 4 p. 9-29 out./dez. 2013.

\begin{abstract}
AMERICAN LIBRARY ASSOCIATION - ALA. Presidential Committee on Information Literacy: Final Report. Disponível em:

$<$ http://www.ala.org/acrl/publications/whitepapers/presidential> Acesso em: 15.08.2014
\end{abstract}

AKERLIND, Gerlese S. Phenomenographic methods: a case illustration. In: BOWDEN, John A.; GREEN, Pam. (Orgs.) Doing Developmental

Phenomenography. Melbourne: RMIT University Press, p. 103-127, 2005

Standards for the 21st-Century Learner. Disponível em:

<http://www.ala.org/aasl/standards-guidelines/learning-standards> Acesso em: 11.10.2014.

BERNARDINO, Maria Cleide Rodrigues; SUAIDEN, Emir; CUEVAS-CERVERÓ. A biblioteca pública e sua função educativa na sociedade da informação. RACIn, João Pessoa, v. 1, n. 2, p. 5-20, Jul-Dez., 2013.

BRUCE, Christine Susan. Las siete caras de la alfabetización em información em la enseñanza superior. Anales de Documentación, n. 6, 2003, pp. 289-294

BRUCE, Harry; LAMPSON, Marc. Informationprofessionals as agentes ofinformationliteracy. Education for Informationn. 20, 2002, pp. 81-106.

CAMPAL GARCÍA, Felicidad. Bibliotecas públicas: escenarios para elaprendizaje. III Congreso Nacional de Bibliotecas Públicas, Madrid: Ministerio de Cultura, Subdirección General de Información y Publicación, 2006. pp. 33-40.

CAMPELLO, Bernardete dos Santos. Letramento Informacional: função educativa do bibliotecário na escola. Belo Horizonte, Autêntica Editora, 2010. 
Letramento informacional no Brasil: práticas educativas de Bibliotecários em escolas de ensino básico. UFMG, 2009. (Tese de doutorado)

CAREGNATO, Sônia Elisa. O desenvolvimento de habilidades informacionais: o papel das bibliotecas universitárias no contexto da informação digital em rede. Revista de Biblioteconomia \& Comunicação, Porto Alegre, v.8, p. 47-55, jan./dez. 2000.

CASTELLS, Manuel. A Sociedade em Rede. 7. ed. v. 1, São Paulo: Paz e Terra, 2003.

CATTS, Ralph; LAU, Jesús. Hacia unos indicadores de alfabetización informacional. Paris: Unesco, 2008.

CHERMAN, Andrea. Valoração do conhecimento nas organizações: percepções dos indivíduos e impactos nas práticas organizacionais. Pontifícia Universidade Católica do Rio de Janeiro, 2013. Tese.

CRAWFORD, Jhon. Editorial: Information literacy and lifelong learning. Library and Information Research. v.37, n. 114, 2013.

CRESWELL, John W. Projeto de Pesquisa. Métodos qualitativos, quantitativos e misto. Porto Alegre: Artmed, 2007.

CRIPPA, Giulia. Pensando o espaço público do presente: a biblioteca pública em sua função social. DataGramaZero Revista de Informação. v.16 n.2 abr/2015

DEMASSON, Andrew; PARTRIDGE, Helen; BRUCE, Cristine. How do public librarians constitute information literacy? $5^{\text {a }}$ Conference on Quantitative Research in IT. Brisbane, nov. 2010.

DUDZIAK, Elizabeth Adriana. Information Literacy: princípios, filosofia e prática. Ci. Inf., Brasília, v. 32, n. 1, pp. 23-25, jan-abr., 2003.

ELMBORG, James. Critical Information Literacy: implications for instructional practice. The Journal of Academic Librarianship, v. 32, n. 2 (2006), pp.192-199.

FLICK, Uwe. Desenho da pesquisa qualitativa. Porto Alegre. Artmed, 2009. 
FUNDAÇÃO GETÚLIO VARGAS. Censo Nacional das Bibliotecas Públicas Municipais: Estudo quantitativo: principais resultados. Brasília: FGV, 2010.

GASQUE, Kelley Cristine Gonçalves Dias. Letramento informacional: pesquisa, reflexão e aprendizagem. Brasília: Faculdade de Ciência da Informação/Universidade de Brasília, 2012.

92, 2011.

. Arcabouço conceitual do Letramento Informacional. Ci. Inf. v. 39, p. 83-

GÓMEZ-HERNANDEZ, J. A.; PASADAS-UREÑA, Cristóbal. La alfabetización informacional em bibliotecas públicas: Situación actual y propuestas para una agenda de desarrollo. InformationResearch, v. 12, n. 3, april 2007.

GONZÁLEZ-UGALDE, Carlos. Investigación Fenomenografica. Magis, Revista Internacional de Investigación en Educación, 7(14), 141-158.

HALL, Rachel. Public Praxis: A vision for critical information literacy in public libraries. Public Lybrarie Quartely, 29 (2), 2010, pp. 162-175.

HARDING, Jane. Information literacy and the public library: we've talked the talk, but are we walking the walk? The Australian Library Journal. 2008, 57(3), pp. 274-294.

HART, Genevieve. The information literacy education readiness of public libraries in Mpumalanga Province (South Africa). Libri, 2006, v. 56, pp. 48-62.

HERRERA-VIEDMA, Enrique. LÓPEZ-GIJÓN, Javier. Libraries social role in the information age. Science. 339, 22 mar 2013.

IFLA. Declaração de Alexandria sobre competência Informacional e aprendizado ao longo da vida. In: National Fórum onInformationLiteracy, 2005. Disponível em: <http://archive.ifla.org/lll/wsis/BeaconlnfSoc-pt.html> Acesso em: 13.08.2014.

Manifesto IFLA/UNESCO sobre a Internet. IFLA/UNESCO: 2006.

Disponível em: <http://www.ifla.org/lll/misc/internetmanif.htm> Acesso em: 15.07.2014. 
INSTITUTO PRÓ-LIVRO. Pesquisa Retratos da Leitura no Brasil. Instituto Prólivro, 2012. Disponível em:

<http://prolivro.org.br/home/images/relatorios_boletins/3_ed_pesquisa_retratos_leitur a_IPL.pdf> Acesso em: 15.01.2015.

JULIEN, Hedi; GENUIS, Shelagh K. Librarians experiences of the teaching role: a national survey of librarians. Library \&Information Science Research. v. 33, 2011, pp. 103-111.

; HOFFMAN, Cameron. Canada's Public Libraries and Information

Literacy Training. Canadian Library Association. 2008, n. 2, pp. 74-77.

KOONTZ, Christie; GUBBIN, Barbara (Orgs.). Diretrizes da IFLA para Bibliotecas Públicas. Brasília: Briquet de Lemos/Livros, 2012.

KUHLTHAU, Carol C. Inside the search process: information seeking from the user's perspective. Journalofthe American Society for Information Science. 42(5):361371, 1991.

. Accommodating the User's Information Search Process: hallenges for InformationRetrieval System Designers. Bulletimofthe American Society for Information Science. v. 25, n. 3, 1999.

LAI, Horng-Ji. Information literacy training in Public Libraries: A case from Canada. Educational Technology \&Society, 2011, 14 (2), pp. 81-88.

LEMOS, Antonio Agenor Briquet de. Para onde vão as bibliotecas publicas. PalavraChave, São Paulo, v. 1, p. 11-12, maio 1982.

LIMBERG, Louise (2000). Phenomenography: relational approach to research on information needs, seeking and use. The New Review of Information Behaviour Research, 2000.

SUNDIN, Olof; TALJA, Sanna. ThreeTheoretical Perspectives onInformationLiteracy. HUMAN IT 11.2, 2012. pp. 93-130.

LOPES, Ana Luiza Szuchmacher Verissimo. Autonomia no trabalho na perspectiva de um grupo de profissionais especializados: um estudo fenomenográfico. Universidade Federal do Rio de Janeiro, 2012. Tese. 
LOZANO DÍAS, Roser. La biblioteca pública del siglo XXI: atendiendo clientes, movilizando personas. Gijón, Asturias: Ediciones Trea, 2006.

LLOYD, Annemaree. Information literacy: Different contexts, different concepts, different truths? Journal of librarianship and information science, 2005, 37 (2), pp. 82-88.

. Information literacy landscapes. Londres: Chandos Publishing, 2010.

MARTON, F. Phenomenography: describing conceptions of the world around us. Instructional Science, 1981 , v. 10, p. 177-200

. Phenomenography. In: TORSTEN, H.; NEVILLE, P. The InternationalEncyclopediaofEducation. 2. ed., v. 8, Pergamon, 1994.

MARTUCCI, E. M. Processo educativo na mediação da informação em biblioteca pública: um estudo fenomenológico. Revista de Biblioteconomia de Brasília, Brasília, 1997, v. 21, n. 2, p. 167-187.

MILANESI, Luís. Biblioteca. São Paulo: Ateliê Editorial, 2013.

A casa da invenção: bibliotecas e centros de cultura. São Paulo: Ateliê Editorial, 2002.

MORAES, Rubens Borba de. O problema das bibliotecas brasileiras. Brasília: ABDF, 1983.

ORTEGA, Cristina Dotta. Relações históricas entre Biblioteconomia, Documentação e Ciência da Informação. DataGramaZero Revista de Ciência da Informação. v.5 n.5, out/2004.

POUSTIE, Kay. Educating for information literacy through the internet: another role of the public library. Australians Public Libraries and Information Services. 12.2 June 1999.

RICHARDSON, Roberto Jarry. Pesquisa Social: métodos e técnicas. São Paulo: Editora Atlas, 1999. 
positividades aolongo da década (2001-2010). Porto Alegre: Universidade Federal do Rio Grandedo Sul,2012. (Dissertação)

SUAIDEN, Emir José. A alfabetização informative e a inclusãonasociedade da informação. In: SALAZAR, P. H. (Coord.). Tendencias de la

AlfabetizaciónInformativaenlberoamérica. México: UNAM, 2012. Disponívelem:

$<$ http://132.248.242.3/ publica/archivos/libros/tendencias_alfabetizacion_informativa. pdf>Acessoem: 25.07.2014.

Paulo: Lisa,1980.

Biblioteca pública brasileira: desempenho e perspectivas. São

A biblioteca pública no contexo da sociedade da informação. Ci. Inf., Brasília, v. 29, n. 2, p. 52-60, maio/ago. 2000.

Leitura e biblioteca em sociedade marcada pelas desigualdades

sociais. Ponto de Acesso (UFBA), v. 8, p. 3-23, 2014.

7-11, 2013.

. La biblioteca pública como espacio social. El Bibliotecario, v. 11, p.

. El impacto social de las bibliotecas públicas. Anales de

Documentación, Murcia - Espanha, v. 5, p. 333-344, 2002.

SJÖSTRÖM, Björn; DAHLGREN, Lars Owen. Applying phenomenography in nursing research. Blackwell Science Ltd, Journal of Advanced Nursing, 40(3), 2002, pp. 339-345.

TARAPANOFF, Kira; SUAIDEN, Emir; OLIVEIRA, Cecília Leite. Funções Sociais e Oportunidades para Profissionais da Informação. DataGramaZero - Revista de Ciência da Informação. v. 3 n.5 out/2002.

TAKAHASHI, Tadao (Org). Sociedade da Informação no Brasil: Livro Verde. Brasília. Ministério da Ciência e Tecnologia. 2000.

UNESCO. The Prague Declaration: towards na information literate society. Praga: UNESCO, 2003. Disponível em:

<http://portal.unesco.org/ci/en/files/19636/11228863531PragueDeclaration.pdf/Pragu eDeclaration.pdf> Acesso em: 15.07.2014. 